COMMITTEE ON SCHOLARLY PUBLISHING IN SOUTH AFRICA

\title{
Report on Grouped Peer Review of Scholarly Journals in Religion, Theology and Related Fields (RTRF)
} August 2013

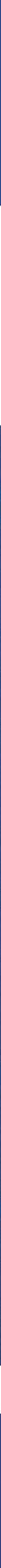


COMMITTEE ON SCHOLARLY PUBLISHING IN SOUTH AFRICA

Report on Grouped Peer Review of Scholarly Journals in Religion, Theology and Related Fields (RTRF) August 2013

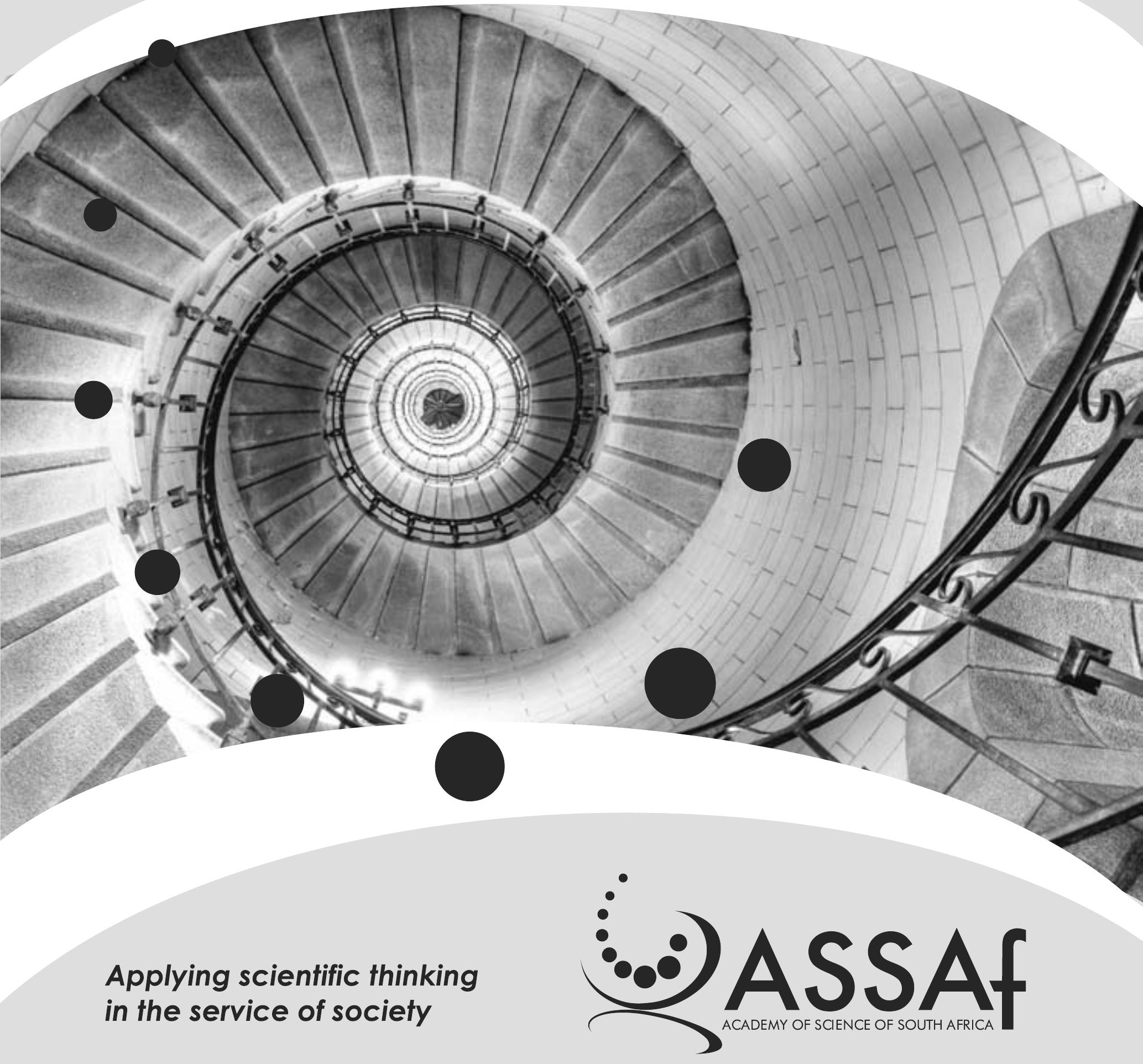




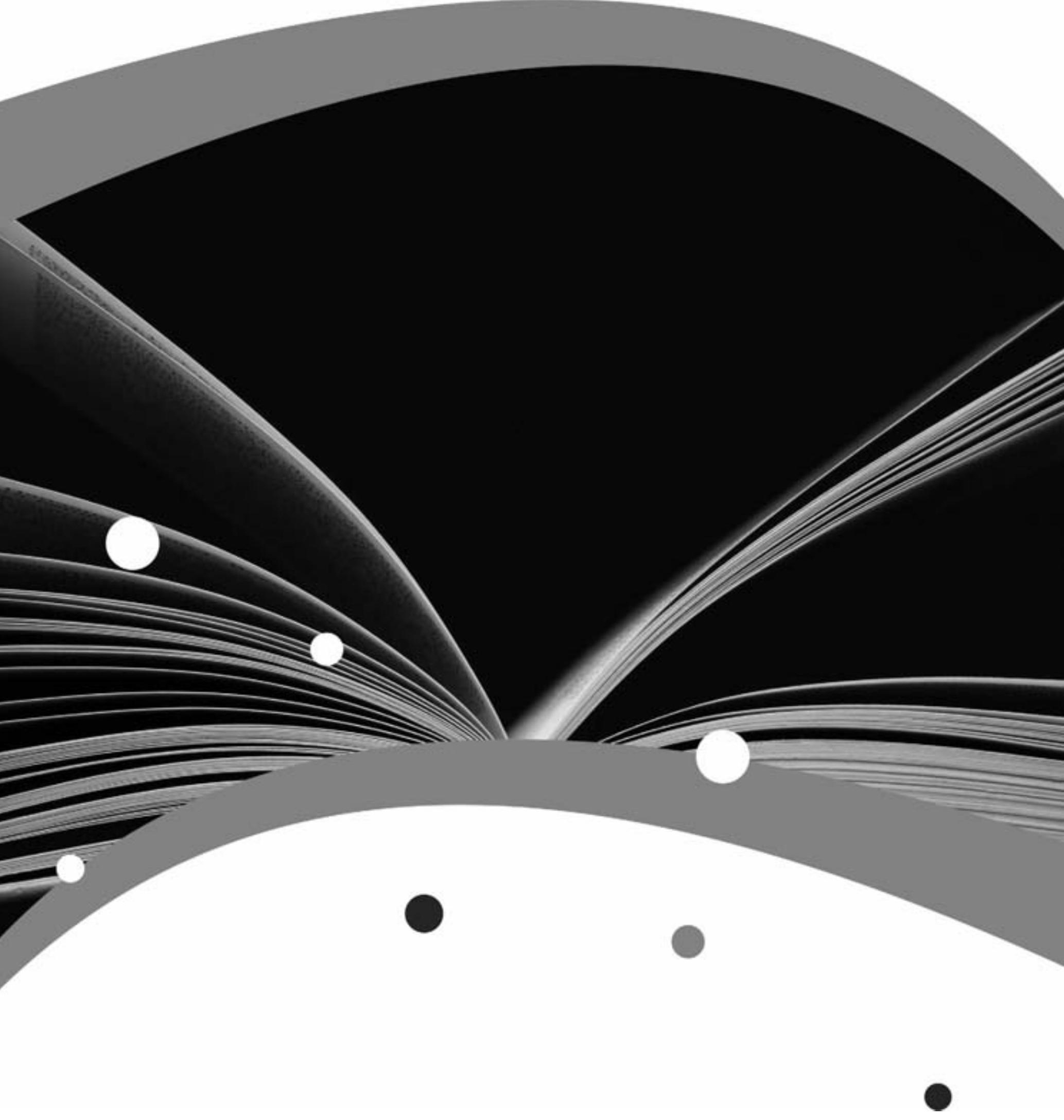




\section{CONTENTS}

$\infty$

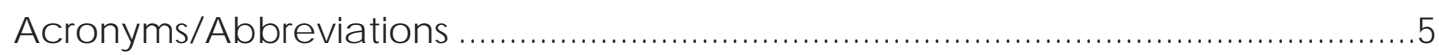

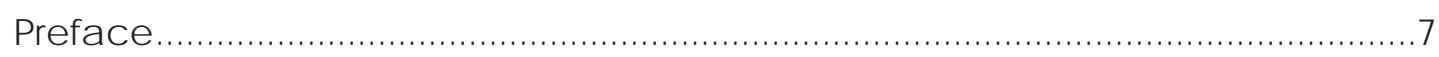

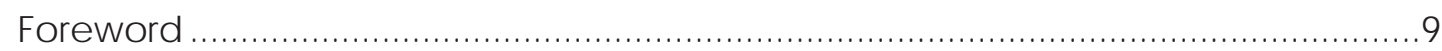

1 Periodic Peer Review of South Afric an Scholarly J oumals: Approved Process Guidelines and Criteria ................................11

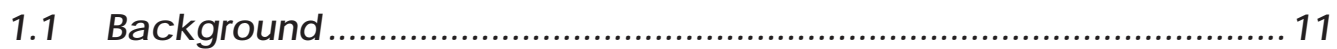

1.2 ASSAf Peer-review Panels (PRPS) .......................................................... 11

1.3 Initial C niteria.............................................................................................. 12

1.4 Proc ess Guidelines............................................................................... 13

1.4.1 Setting up Panels .........................................................................13

1.4.2 Setting up and Organising the Panels....................................14

1.4.3 Panel Meetings and Procedures.................................................15

1.4.4 Post-meeting Procedures and Panel Reports...........................16

2 Special Considerations Conceming South African Religion, Theology and Related Fields J oumals (RIRF) ............................. 17

3 Panel Members................................................................. 19

4 Consensus Reviews of J oumals in the Group................................2 20

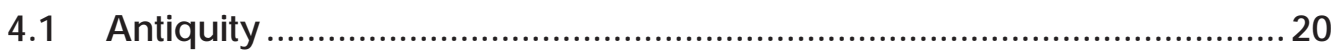

4.1.1 Acta Patristica et Byzantina (New Title: J oumal of Ea rly Christian History (J ESH)) ...............................................................20

4.1.2 Old Testament Essays (New Series) ...........................................24

4.1.3 Neotestamentica - J oumal of the New Testament Soc iety of South Afric a (NTSSA) ..............................................27

4.1.4 J oumal for Semitic S/Tyd sknif vir Semitistiek.................................30

4.1.5 Ekklesia stikos Pha ros.............................................................33

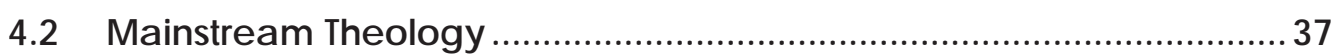

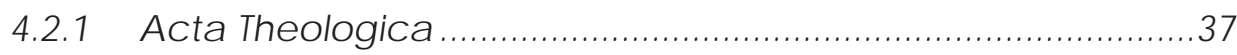

4.2.2 J oumal of Theology for Southem Africa ...................................39

4.2.3 Verbum et Ecclesia ..................................................................41

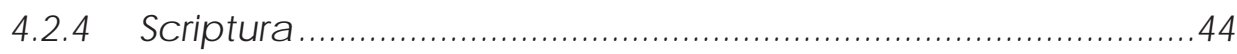


4.3 Specific Theological Traditions ............................................................46

4.3.1 In Die Skriflig (New Title: In Luce Verbi) ....................................46

4.3.2 Nederduits-Gereformeerde Teologiese Tyd skrif (NGTT) ...........48

4.3.3 South Afric an Baptist J oumal of Theology ................................51

4.3.4 HTS Teologiese Studies - Theological Studies (Incorporating Practic al Theology) .........................................53

4.4 Science/ Scholarship in Theology ..................................................56

4.4.1 Koers: Bulletin for Christian Schola rship .................................56

4.4.2 Tydsknif vir Christelike Wetenskap/

J oumal for Christian Sc hola rship .............................................59

4.5 Religious Studies............................................................................62

4.5.1 Theologia Viatorum: J oumal of Theology and Religion In Africa........62

4.5.2 J oumal for the Study of Religion ...............................................64

4.5.3 J oumal of Construc tive Theology: Gender, Religion and Theology in Africa (Name changed to J oumal of Gender and Religion in Africa ).................................................................66

4.5.4 Missionalia: J oumal of the Southem Afric an Missiologic al

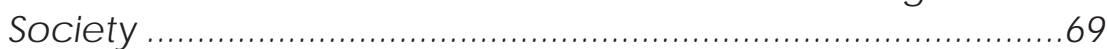

4.5.5 Studia Historiae Ecclesia stic ae ................................................72

4.6 Specific Religious Traditions .................................................... 75

4.6.1 J oumal for Isla mic Studies........................................................75

4.6.2 Nidan: Intemational J oumal for the Study of Hind uism.............77

4.6.3 Intemational J oumal for Religious Freed om..............................80

\section{Appendix A:}

Questionnaire sent to Each Editor of J oumals being Peer Reviewed

\section{Appendix B:}

Requests to Independent Peer Reviewers.................................................86

\section{Appendix C:}




\section{ACRONYMS}

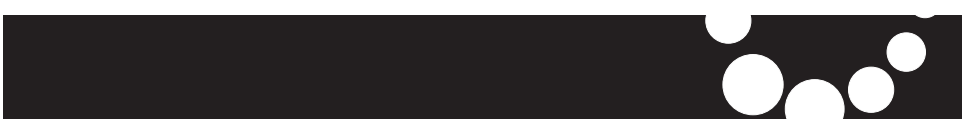

\section{IABBREVIATIONS}

\begin{tabular}{|c|c|}
\hline AB & Advising board \\
\hline AGM & Annual general meeting \\
\hline AJOL & African J ouma Is Online \\
\hline ASSAf & Academy of Science of South Africa \\
\hline ATLA & Americ an Theologic al Library Association \\
\hline BUSA & Baptist Union of South Africa \\
\hline CHE & Council on Higher Education \\
\hline CHSSA & Church History Society of Southern Africa \\
\hline CREST & Centre for Research on Science and Technology \\
\hline CSPISA & Committee on Scholarly Publishing in South Africa \\
\hline DHET & Department of Higher Education and Training \\
\hline DST & Department of Science and Technology \\
\hline $\mathbf{F H U}$ & Fort Hare University \\
\hline HESA & Higher Education South Africa \\
\hline HEQC & Higher Education Quality Committee \\
\hline IAB & Intemational advisory board \\
\hline IAHS & Institute for Afro-Hellenic Studies \\
\hline IRF & Institute for Religious Freedom \\
\hline IIRF & Intemational Institute for Religious Freedom \\
\hline J RF & Intemational J oumal for Religious Freedom \\
\hline JTSA & Joumal of Theology for Southem Afric a \\
\hline MRC & Medical Research Council \\
\hline NGTT & Nederduits-Gereformeerde Teologiese Tydskrif \\
\hline NMMU & Nelson Mandela Metropolitan University \\
\hline NRF & National Research Foundation \\
\hline NSBPF & National Scholarly Book Publishers' Forum \\
\hline NSEF & National Scholarly Editors' Forum \\
\hline NISSA & New Testament Society of South Africa \\
\hline NWU & North-West University \\
\hline OTSSA & Old Testament Society of South Africa \\
\hline PRPS & Peer-review panels \\
\hline RU & Rhodes University \\
\hline SABJT & South African Baptist J oumal of Theology \\
\hline SAMS & Southern African Missiological Society \\
\hline SciElO & Scientific Electronic Library Online \\
\hline SciElO-SA & Scientific Electronic Library Online - South Africa \\
\hline SASNES & Southern African Society for Near Eastern Studies \\
\hline SHE & Studia Historiae Ecclesiastic ae \\
\hline SU & Stellenbosch University \\
\hline UCT & University of Cape Town \\
\hline UFS & University of the Free State \\
\hline U] & University of J oha nnesburg \\
\hline UKZN & University of KwaZulu-Natal \\
\hline $\mathbf{U L}$ & University of Limpopo \\
\hline UNISA & University of South Africa \\
\hline UP & University of Pretoria \\
\hline UWC & University of the Western Cape \\
\hline
\end{tabular}




\section{Ste ang}

a $\mathrm{C}$

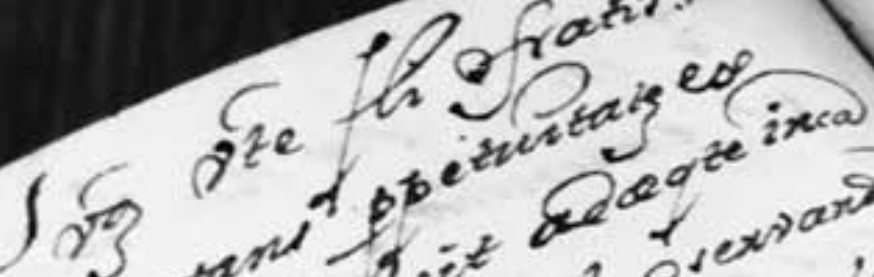
jec

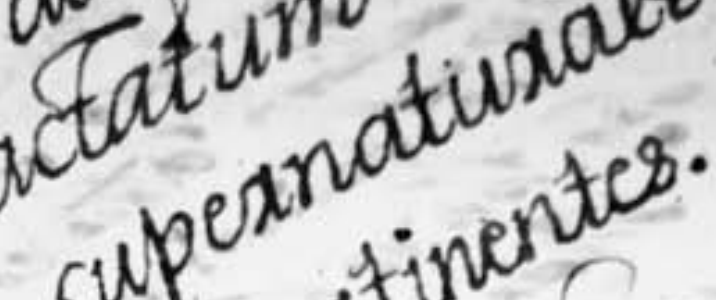

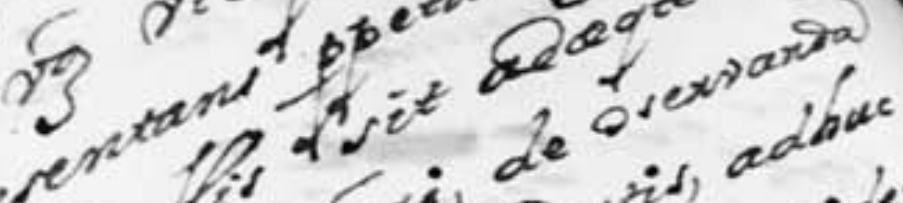

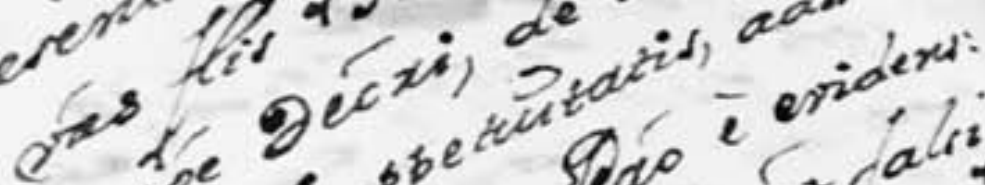

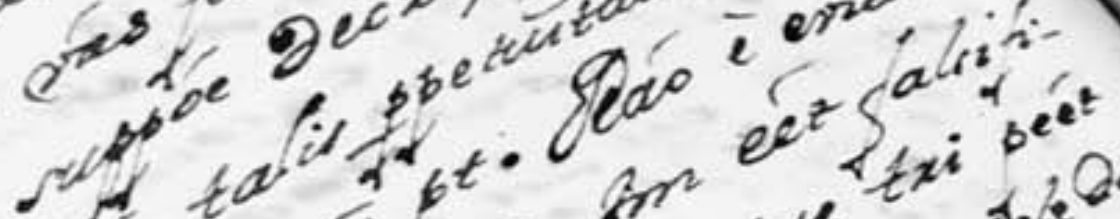

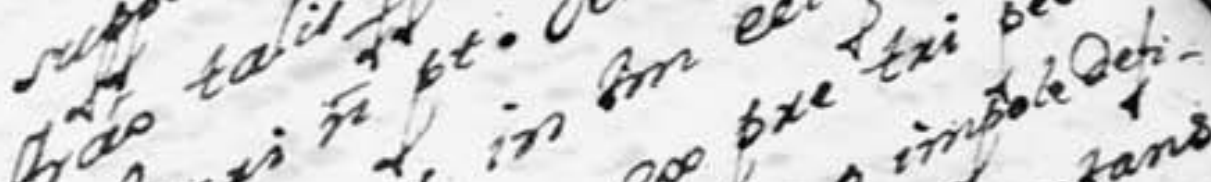
ats ats

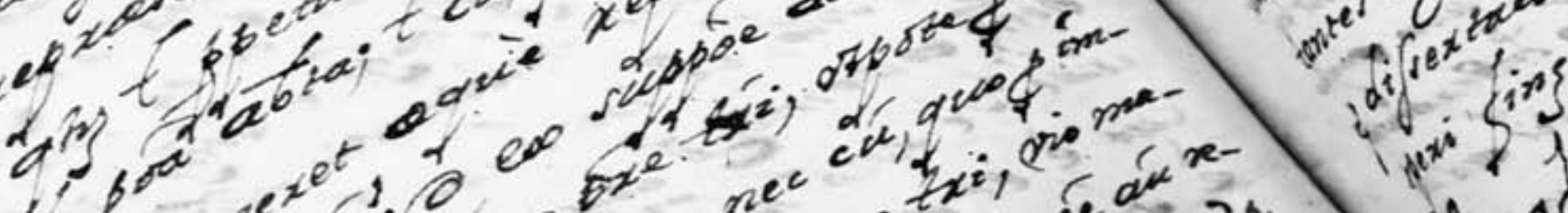

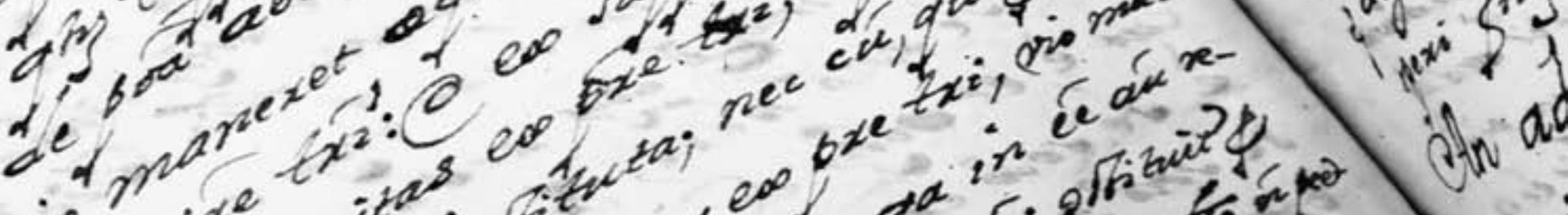

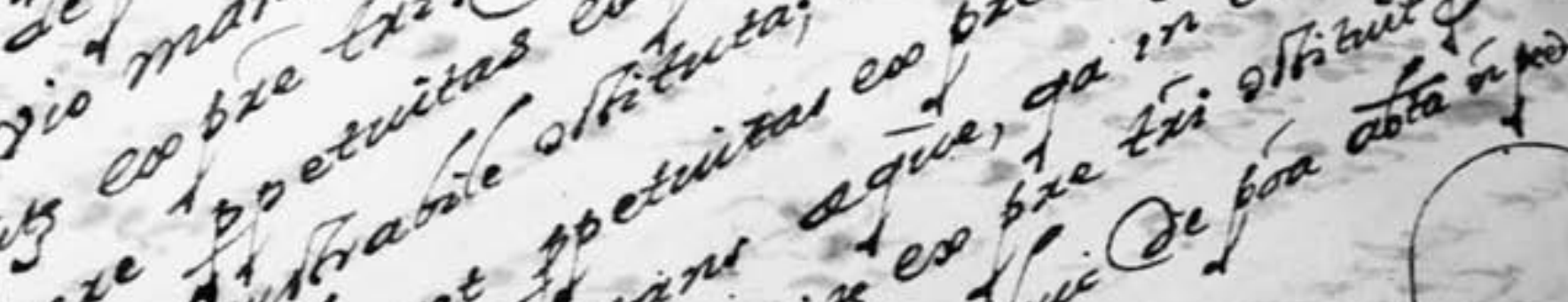
abe pereres or

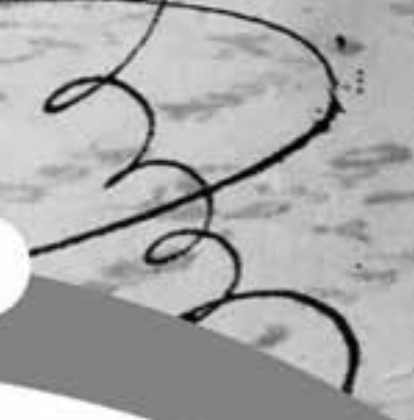




\section{PREFACE}

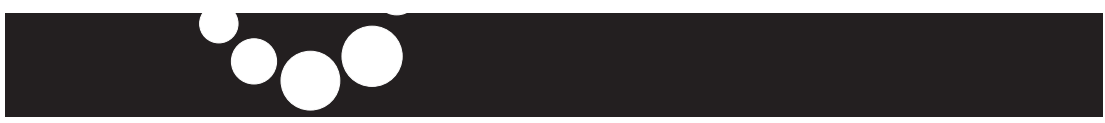

This report marks the third in the series of discipline-grouped evaluations of South African scholarly jouma Is. Ultimately, it is intended that all schola rly jouma ls in the country will have been subjected to independent, multiple peer review as part of a quality assurance process initiated by the Academy of Science of South Africa (ASSAf). The quality assurance process is a precursor to the identification of journal titles to be loaded on to the open access platform, Scientific Electronic Library Online (SciELO)-South Africa. Only journals of a sufficiently high quality will be included in this fully indexed, free online, multinational platform, now also to be directly featured on the ThomsonReuters Web of Knowledge portal.

The traditional focus of peer review is on a single journal article, book chapter or book. It is less common to subject joumals to independent, multiple peer review, as these a re usua lly eva luated in qua litative, reputational tems, or, bibliometric ally, by mea ns of impact factors.

Peer review of South African scholarly journal titles thus required the development of a new methodology that was piloted successfully with the first two discipline-grouped peer-review reports, published in 2010 on the Social Sciences and Related Fields, and the Agricultural and Related Basic Life Sciences. This has not been achieved without difficulty, as the process is unfamiliar to reviewers accustomed to reviewing single artic les.

ASSAf has confidence in this ambitious programme aimed at assuring that the bulk of South African schola rly jouma Is is of a high quality. The process goes beyond the above-mentioned fa miliar joumal assessment approaches by providing concrete recommendations to ena ble the editor(s) of journals not deemed to be of a sufficient standard to take corrective action and to reapply for evaluation.

In summary, the process was centred on multi-perspective, discipline-based evaluation panels appointed by the Academy Council on the recommendation of the Academy's Committee on Scholarly Publishing in South Africa (CSPiSA); journal editors were requested to complete specially designed questionnaires, and peer reviewers were selected from a spectrum of scholars in the fields concerned. Each was asked to provide answers to a set of questions, which addressed the quality, scope and focus of the peer-reviewed artic les in the joumals under review, the authorship generally, and the presence or absence of enrichment features, such as editorials, topical reviews, book reviews and news and views articles. (The editors' questionnaire and peer reviewers' set of questions are provided as appendices to this report.)

Each discipline-based evaluation panel met to discuss the individual peer reviews and questionnaires and consolidated them into a consensus review for each joumal. Final formulations and recommendations were prepared, including suggestions for improvement from both the peer reviewers and the panel. The responsible editors were given an opportunity to check the accuracy of the information in each individual journal report, and the final version of the report was submitted for approval to the ASSAf Committee on Scholarly Publishing in South Africa and the Council of the Academy of Science of South Africa.

As the third in the series of reports, it is evident that much has been leamed from the two pilot discipline groups and that going forward; the process will become more streamlined such that subsequent reports will follow in rapid succession. 
I would like to thank the members of the evaluation panel, particularly Professor Wieland Gevers, Chair of the Committee on Scholarly Publishing in South Africa, for his leadership in this quality-assurance process. I acknowledge the important role played by the staff of the Academy in supporting the process; Mrs Susan Veldsman, Director of the Scholarly Publishing Unit, and the many Project Officers who worked under her direction over the years, namely, Mr Thabo Radebe, Mr Zwelibanzi Ndayi and Ms Gugulethu Mtsweni. Ms Patricia Scholtz is thanked for copy editing. Finally, I acknowledge the contribution of the many individual peer reviewers who have each contributed towards strengthening the quality of South African scholarly journals.

\section{Prof Roseanne Diab}

Executive Officer: Academy of Science of South Africa
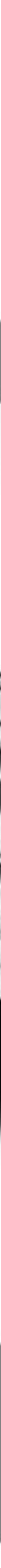


\section{FOREWORD}

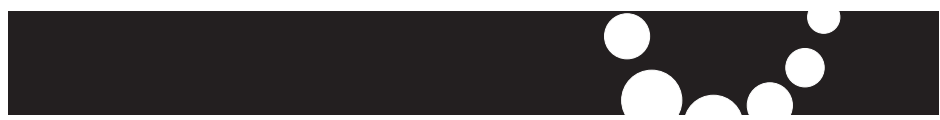

On 1 February 2013, the Department of Higher Education and Training published a call for public comments on the proposed improvements to the Policy and Procedures for Measurement of Research Output of Public Higher Education Institutions, 2003, in the Govemment Gazette. This formed part of a consultative process with the higher education sector. The Department welcomes inputs and comments made on the proposed improvements to the policy which aim to increase research productivity and reward high-quality research published in accredited journals, books and published conference proceedings. There can be no doubt that the policy has propelled the performance of the sector on research outputs and that momentum has to be sustained and improved further. Thus, the proposed improvements are meant to propel the sector further in this regard.

In terms of the proposed improvements, the policy seeks to include additional journal lists and/ or indices for purposes of subsidy alloca tions. Moreover, all indices or lists will be communicated separately and well in advance, rather than included in the actual policy. The Department will determine, in consultation with the sector, which joumal lists and indices will be approved each year. As it is the current practice, the Department will issue the indices and the approved List of South African Journals on or before 31 January of every year. In an attempt to improve quality of local journals, the policy seeks to encourage all journals in the Approved List of South African Journals to develop to intemational standards, in order to apply for listing on accredited intemational lists or indices.

Addressing the decline in scholarly book publications and a subsequent report on Scholarly Books: Their Production, Use and Evaluation in South Afric a Today in 2009 by the Academy of Science of South Africa, the policy proposes that a book be subsidised to a maximum of ten units or a portion thereof, based on the number of pages being claimed relative to the total number of pages of the book. The policy further suggests the improvement in the number of units for book publications in order to encourage production of, and publications, in books. The assumption is that academic books are important.

The Department seeks to develop a list of reputable publishers as it is difficult for academics or researchers to obta in evidence of peer review from the publishers, both locally and intemationally.

The Department has improved the processes and procedure by which published conference proceedings are subsidised. More improvements in this regard are addressed in the policy. All the approved indices camy a large number of published conference proceedings which undergo quality sc rutiny.

The Department welcomes suggestions on the improvement of its work and that of this policy, in particular.

The overall objective has to be that of constantly improving the performance and measurement of the sector. Most importantly, the qua lity of research outputs needs to be improved.

It is a ntic ipated that the quality of resea rch outputs, in order to enhance and reward where measureable, will be emphasised over the next few years. 
The policy will be focused on qua lity resea rch output mea surements and rewa rd to the institutions. It is important that universities recognise all outputs, including those not addressed by this polic $y$.

Additions to the policy regarding the recognition of creative outputs are currently undertaken. While textbooks and other outputs are important, universities are urged to put systems in place in order to include these.

\section{Mahlubi Mabizela}

Chief Director: University Education Policy and Development

\section{Walter Ntuli}

Senior Administrative Clerk: University Education Policy and Development

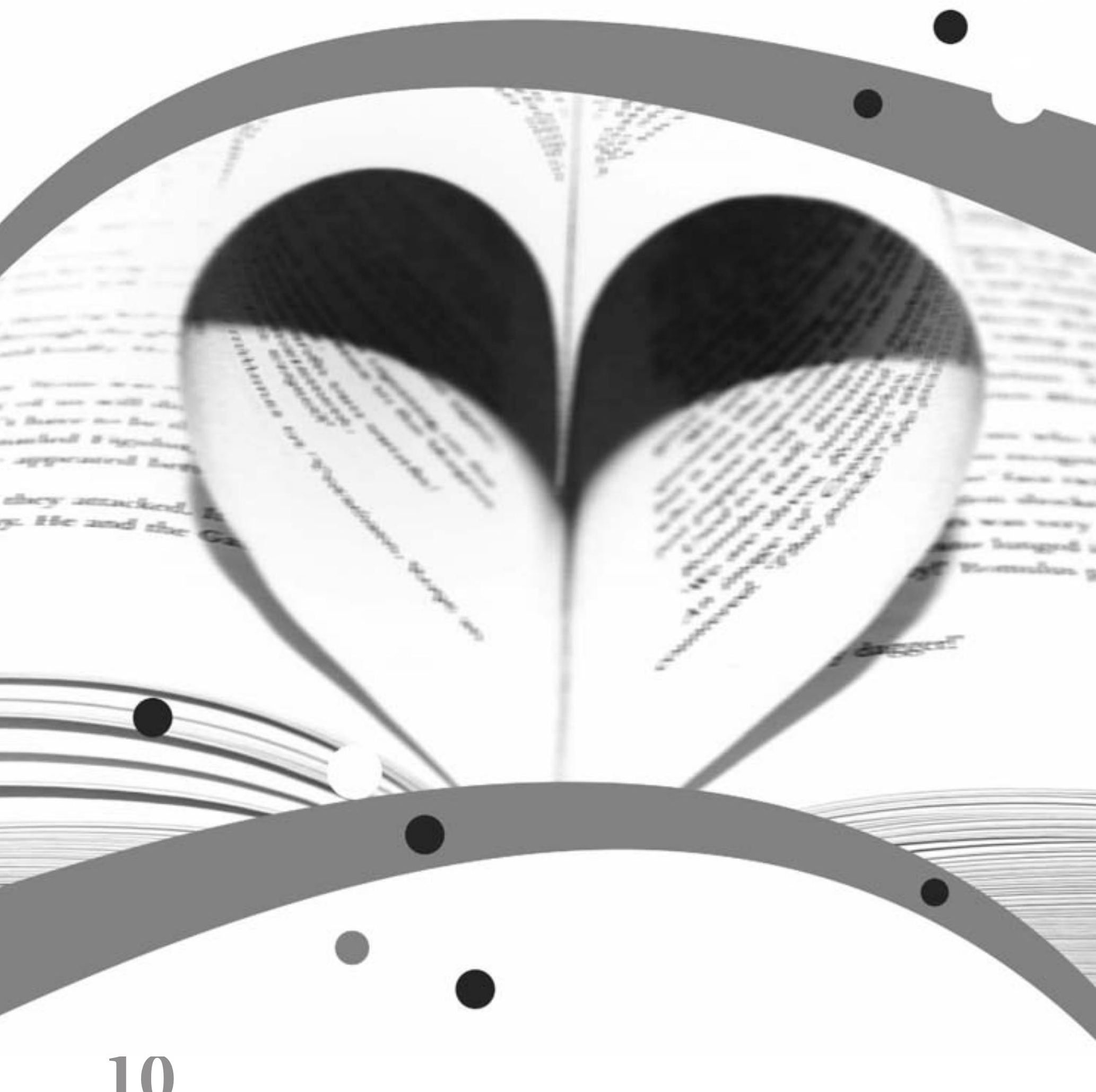




\section{Periodic Peer Review of South African Scholarly Journals: Approved Process Guidelines and Criteria}

\subsection{Background}

At the launch of the ASSAf-led National Scholarly Editors' Forum (NSEF) held on 25 July 2007, 112 participants supported ASSAf and its Committee on Scholarly Publishing in South Africa (CSPiSA) took the lead in implementing of Recommendation 5 of the 2006 ASSAf Report on A Strategic Approach to Research Publishing in South Africa. This recommendation dealt specifically with the need for a system of quality assurance for the more than 260 scholarly joumals that are ac credited by the Department of Education:

Recommendation 5: thatASSAf be mandated jointly by the Departments of Education and Science and Technology to cany out extemal peer review and associated quality audit of all South African research journals in five-year cycles, probably best done in relation to groups of titles sharing a partic ular broad disciplinary focus, in order to make recommendations for improved functioning of each joumal in the national and intemational system.

\subsection{ASSAf Peer-review Panels (PRPs)}

The qua lity-assurance system for jouma ls is conducted prima rily through discipline-grouped peer reviews camied out by a series of purpose-appointed peer-review panels (PRPs) drawn from the ranks of researchers and other experienced scholars in and around the fields concerned in each case, as well as persons with practical (technical) publishing experience. The proposed ASSAf PRPs are overseen by the CSPiSA, but appointed by the Academy Council. Their draft reports are sent to relevant stakeholders for comment and relevant inputs, before finalisation by the PRP concerned, and final consideration sequentially by the CSPiSA and the ASSAf Council.

The following quote from the ASSAf report clarifies the approach to be followed in the review of the joumals and some aspects of the approach proposed:

"The periodic, grouped quality assurance-directed peer review of South African research periodicals would function analogously to the quality audits of the Council on Higher Education/ Higher Education Quality Committee (CHE/ HEQC), would be developed as an outcome of the Editors' Forum, and would focus on: the quality of editorial and review process; fitness of, and for purpose; positioning in the global cycle of new and old journals listed and indexed in databases; financial sustainability; and scope and size issues. The ASSAf panels carrying out the reviews would each comprise six to eight experts, some of whom would not be directly drawn from the areas concerned, and would require data-gathering, interviews, and international comparisons, before reports with recommendations are prepared, approved, and released to stakeholders such as national associations, the Departments of Science and Technology and of Education, the CHE/HEQC, the NRF and HESA."

It must be emphasised that the main purpose of the ASSAf review process of journals is to improve the quality of scholarly public ation in the country in a manner that is consonant with traditional scholarly practices, primarily voluntary peer review; it is not an attempt to control these publications in any way. ASSAf respects the independence and freedom of researchers and of 
the research process itself as important preconditions for the critical and innovative production of new knowledge. At the same time, the work of South African researchers has to be assessed, both qua lita tively and qua ntita tively, as part of the global community of scholars and scientists, and in this respect ASSAf has an obligation to contribute to the improvement of quality of such work where possible.

\subsection{Initial C riteria}

A number of criteria were explored in the section (Chapter 4) of the ASSAf report that dealt with the survey of over 200 then-current editors of accredited South African scholarly journals. Other possible criteria were proposed in other sections of the report, or have since been suggested by members of the CSPiSA or the National Scholarly Editors' Forum. These are grouped and listed below (they have been consolidated in the questionnaire presented in Appendix A):

\subsubsection{Editorial Process-related Criteria: Generally based on the Code of Best Practice in Editorial Disc retion and Peer Review developed by ASSAf}

- $\quad$ Longevity of the journal (continuous or discontinuous), in years?

- $\quad$ Number of original peer-reviewed papers published per year during the last five years, plus number of manuscripts submitted, plus number rejected out-of-hand or after peer review? Average length of published papers? 'Author demography' of papers submitted and published?

- $\quad$ Number and nature of peer reviewers used per manuscript and the overall number per year, including institutional and national/intemational spread, plus quality (as per Code of Best Practice) and average length of peerreview reports?

- $\quad$ Average delay before publication of submitted manuscripts? Frequency of publication?

- $\quad$ Professional stature and experience of the editor? How selected? How long in service? Success or otherwise in addressing the major issues in the field, through commissioning of reviews/articles, editorial comment, etc.?

- Number and professional stature/experience of editorial board members, plus selection processes, tumover, and nature of involvement in handling of manuscripts or in other functions? If international members serve on the board (desirable), are they a mix from developed or developing countries?

- $\quad$ Existence and nature of editorial policy/guidelines, plus how often revised/ updated? Conflict of interest policy (e.g. how manuscripts are assessed when submitted by an editor or board member as author/co-author?)

- $\quad$ Errata published - how many per year?

- Value-adding features, such as editorials, new and views, correspondence on papers, reviews, policy/topical fora, etc. - how many, and how generated? What proportion of total pages in journal issues?

- $\quad$ Any peer-review process of journal already in place (e.g. by professional association)?

\subsubsection{Business-related Criteria}

- $\quad$ Frequency and regularity ('on time') of publication?

- $\quad$ Print runs? (Redundant stock? Direct versus indirect distribution to readers?)

- $\quad$ Production model and service provider(s)?

- $\quad$ Paid and unpaid advertising?

- $\quad$ Sponsorship? What quid pro quos?

- $\quad$ Paid and unpaid subscription base? How marketed? Cost level of print and (if applicable) e-subscriptions?

- $\quad$ E-publication? If so, what website/portal, and access possibilities for users? What evaluation is done, especially in respect of tagging and searchability? 
- $\quad$ Are there $\mathrm{html} / \mathrm{xml}$ and PDF versions, or only PDF? Are multimedia used?

- What portals for open access, if provided? If not e-published, is this being considered, and how?

- Total income and expenditure per annum?

- Distribution to international destinations?

- Indexed in Thomson ISI and/or IBSS, or any other international database? If so, for how long and how continuous?

- $\quad$ Offers to purchase from multinational publishers?

- Copyright arrangements?

\subsubsection{Bibliometric Assessments}

- $\quad$ Citation practice - how many authors listed?

- If applicable, ISI-type impact factors (and various derivatives) over last five years?

- $\quad$ Are reviews a regular/increasing feature?

- If articles are not in English, are English abstracts mandatory?

\subsection{Process Guidelines for Setting up the Panels, Peer Reviewers, Panel Meetings and Reports for the Subject Peer Review of J oumals}

\section{Background to ASSAf Peer-review Panels (PRPS)}

The qua lity a ssurance system for joumals is conduc ted primarily through disc ipline-grouped peer reviews caried out by a series of purpose-appointed peer-review panels (PRPs) drawn from the ranks of researchers and other experienced scholars in and around the fields concerned in each case, as well as persons with practical (technical) publishing experience. The proposed ASSAf PRPs are overseen by the CSPiSA, but appointed by the Academy Council. Their draft reports are sent to relevant stakeholders for comment and relevant inputs, before finalisation by the PRP concerned, and final consideration sequentially by the CSPISA and the ASSAf Council.

\section{Role of the Sc holarly Publishing Unit}

An ASSAf project officer of the Scholarly Publications Unit is assigned to support each panel chair, but reports to the Director of the Scholarly Publishing Unit in terms of review logistics and the production of draft and final review reports. The project officer is responsible for the following issues and a c tivities:

- $\quad$ selection and appointment of the panel members;

- $\quad$ obtaining completed questionnaires from editors;

- $\quad$ organising panel activities, including meetings; selecting independent peer reviewers for each journal or groups of titles;

- $\quad$ drafting consolidated version one (V1) reports;

- $\quad$ obtaining CSPiSA and ASSAf Council approval for final, publishable panel reports.

\subsubsection{Setting up Panels}

The proposed PRPs is chaired by an ASSAf Member, appointed by the Council, who assumes accountability for the panel's work in helping to developing a credible quality-assurance mechanism for South African scholarly journals.

\section{Selecting Panel Members}

- $\quad$ The appointment process of PRPs members is managed by the Chair of the Committee on Scholarly Publishing in South Africa (CSPiSA) until the panel and its chair have been appointed. 
- $\quad$ CSPiSA members are asked to assist in preparing a list of at least 12-13 na mes, of whom the last four to five shall be considered to be potential alternates to the first seven to eight.

- $\quad$ A typical PRP consists of six to eight members.

- $\quad$ Each name must be accompanied by critical personal and career detail, as well as a brief motivation, to enable the CSPISA, and later the ASSAf Council, to apply its mind to the question of constituting a best-possible, most-competent PRP.

- $\quad$ The draft list of potential members is published on the ASSAf website, and also circulated for comment to members of the National Scholarly Editors Forum, at least two weeks before the Council meeting where the appointments are to be made.

- $\quad$ All comments received will be noted in making the final decision.

- $\quad$ All provisionally listed persons are required to complete and submit conflict of interest forms prior to the Council's consideration of the list in question.

\section{Criteria for Panel Membership}

- $\quad$ The individuals selected to serve on a panel should have experience and credibility in the disc iplines under review, or in related disciplines, or must be senior scholars who may be from a completely different discipline. Generally, the composition should be a mix of disciplinary specialists, specialists in areas cognate to the broad disciplinary area concemed, and 'wise people' who are steeped in scholarly practices and are drawn from any broad disc iplinary a rea (respectively in an approximate ratio of 3:3:2).

- The panel members should have demonstrable expertise and experience in both the editing and peer-review aspects of research joumals.

- It is not necessary that all panel members be experts in both editing and peer-review aspects - a mix of senior academics and a few active editors (of joumals not under review) is appropriate - but all should have some appreciation of both editing and peer review.

- At least one member should have direct practical (technic al) experience of publishing.

Persons selected as panel participants will typically be drawn from ASSAf Members, a ca demic institutions, science councils a nd consultants.

\section{Conflict of Interest}

- It will be necessary to take care to avoid real or perceived conflicts.

- Committee expertise, balance and conflict of interest are discussed at the first meeting (and may again be discussed at any later meeting) of PRPs, and recommendations to resolve problematic issues brought through the SPU (Secretariat) to the ASSAf Council for possible amendment of the composition of PRPs.

- $\quad$ Panel members are requested to submit written conflict of interest statements, and are bound to report any new potential sources of conflict of interest during the quality review process.

\subsubsection{Setting up and Organising the Panels}

Organisation of the panel is conducted by its chair, supported by the assigned project officer. The activities related to organisation typically include:

- $\quad$ Planning and costing the review and panel activities.

- $\quad$ Obtaining completed questionnaires from each editor/equivalent (publishing logistic s foc us). 
- Identifying suitable peer reviewers for each joumal or group of titles (content quality foc us).

- $\quad$ Assembling hard copies of joumals for use by the panel.

- $\quad$ Establishing panel meeting dates, assigning tasks, and collating materials.

- $\quad$ Preparing and distributing pre and post-meeting materials (draft Version 1 Reports, i.e. assembled peer reviews and editor's questionnaires, in template form).

- $\quad$ Taking responsibility for post-meeting activities, including draft Version 2 report preparation, circulation for comment to panelists and editors, and preparation and processing of final reports.

- $\quad$ Evaluation of panel processes.

\section{Selection of Peer Reviewers (See above)}

- $\quad$ At least two, but preferably three, independent peer reviewers, as well as altema tive reviewers, must be agreed upon by the panel for each title or group of similar titles.

- Members of the CSPISA and the ASSAf Membership in general will be given an opportunity to volunteer through a specific written call.

- $\quad$ Other candidates will be sought from lists of NRF and MRC grant-holders and/or science council research-active staff.

- $\quad$ The process of selection is overseen by the panel chair. The final agreed appointments of willing volunteer reviewers a re made by the panel itself.

- $\quad$ Conflicts of interest must be avoided - thus current or former editors cannot become peer reviewers of the journals concerned; this also applies to current members of editorial boards.

- $\quad$ The project officer must arrange access to hard or e-copies of the journals under review by independent experts.

- $\quad$ The core questions to be answered in each case must be provided to peer reviewers, who should be asked to ensure that these questions are all addressed in their reviews.

\subsubsection{Panel Meetings and Procedures}

\section{Preparations}

- $\quad$ The ASSAf project officer is responsible to draw up the Version 1 (V1) report of each journal. Each reviewer's answers should be consolidated under the standard headings of the draft; each input as a separate paragraph. The editor's questionnaire should also be inserted as a single item under 'business aspects'.

- The documentation (editors' questionnaires, peer-review reports) should be sent out by email to all panelists at least two weeks prior to the panel meeting.

- $\quad$ Conveners of sub-sets of journals should be alerted at this time to their role at the forthcoming panel meeting - to present the joumals in the set, and to make recommendations for discussion and elaboration. If unable to attend, they should be asked to submit written notes for presentation to the panel by the convener.

- Ideally, hard copies of issues of joumals to be considered should be available at the meeting, but if logistic ally impossible, this can be dispensed with.

- A quorum of at least two-thirds of the members of PRPs must be guaranteed at any meeting, otherwise a new date must be sought.

- $\quad$ Panelists should be informed at the same time that hard copies of all documentation will be available at the meeting, in bundlescontaining the completed editor's questionnaire and reviewers' reports for each journal title, for collection at the start of the meeting. 
- The responsible project officer should ensure that at least two peer reviews, and preferably three, are in hand for each title by the time of the initial dissemination of materials, or, by default, by the date of the meeting, for tabling on the day.

\section{Meeting}

- J oumal titles should be considered in sub-sets, as per the above.

- Consensus answers to each of the criteria should be agreed seriatim as per a convener's spoken summary, and noted by the project officer in attendance.

- Partic ular attention should be paid to reaching agreement on recommendations in respect of:

(a) an invitation to the publisher/editor to join the SciELO platform (note the special criteria on frequency of public ation and a nnual number of original peer-reviewed articles);

(b) a recommendation to the DHET on accreditation in its list of SA journals in which any article is considered as a valid research output;

(c) if not recommended, suggestions for improvement that would make it possible to make an invitation and/or recommendation under 2 (iii) (a) or (b):

(d) suggestions for improvement or enhanced function, generally.

\subsubsection{Post-meeting Procedures and Panel Reports}

- When producing a Version 2 report the three paragraphs in each item have to be consolidated to produce a consensus version.

- $\quad$ A detailed and motivated draft Version 2 report of each peer-review panel's findings and recommendations is prepared by the assigned project officer, working closely with the panel chair.

- $\quad$ The project officer and convener should reach agreement on the record of the meeting in respect of all outcomes, within no more than two weeks. The meeting record should be sent for comment and ratification to all panellists (including those who were not able to attend the meeting) and ask for replies within one week.

- $\quad$ The convener should prepare a final version of the meeting record, and submit a copy of each journal-specific item as a privileged communication to the editor concemed, for written comment within no more than two weeks in which to respond.

- $\quad$ The convener should identify any editor's comment that might materially change the recommendations in the record, and submit these to the panel for consideration and decision.

- $\quad$ The finally agreed-upon record should be submitted to the CSPiSA for approval, before submission in turn to the ASSAf Council, and public release. 


\section{2 \\ $\Omega$}

\section{Special Considerations concerning South African Religion, Theology and Related Fields Journals (RTRF)}

Religion, religious texts and the study of these have existed for a long time. So has the struggle for the academic study of religion to be recognised as a human and/or social science. This is part of a larger epistemological contestation about what constitutes knowledge and the role of the Enlightenment rationalist foundation in determining this. These debates a re not only located in the huma nities or social sciences (e.g. theology versus religion studies, or religion studies versus anthropology) but are also evident in the natural science debates on the greater authenticity of, for example, chemistry over physic s or psychiatry over psychology. While these debates on the hierarchy of disciplines do not loom large in the South Africa academic community, they are nonetheless not without consequences for fields such as religion and theology.

Attempts continually to improve the quality of their work as academics in these fields involve striving for excellence, and making ceaseless attempts to quantify and work towards effective quality assurance. This is an inherent dimension and the basic aspiration of the work of scholars in these fields. It is in this spirit, that the periodic peer review of South African scholarly journals was first proposed by the ASSAf-led National Scholarly Editors Forum (NSEF) in July 2007.

The task of evaluating over 250 national journals accredited by the Department of Higher Education and Training is an immense one, and to ensure that this be made manageable, the NSEF endorsed the recommendation of the 2006 ASSAf Report on A Strategic Approach to Research Publishing in South Africa:

Recommendation 5: that ASSAf be mandated jointly by the Departments of Education and Science and Technology to carry out external peer review and associated quality audit of all South African research journals in five-year cycles, probably best done in relation to groups of titles sharing a particular broad disciplinary focus, in order to make recommendations for improved functioning of each journal in the national and international system.

This report deals specifically with the cluster of titles dealing with religion and theology and related fields. As is the case within virtually all academic disciplines, the task of demarcating fields of enquiry or focus are quite complex, ever-unfolding and invariably imperfect. ASSAf has, however, benefitted from the extensive input that went into this process from its conception.

This report is exhaustive. The rigorous process that was followed in constituting the purpose-appointed peer-review panels, the gathering, collating and deliberating of the data, and the formulating of consensus opinions by the PRP is detailed. In addition, individual editors were given an opportunity to preview our conclusions, correct errors of fact.

The cooperation from the editors of the joumals reviewed was exceptional, and is deeply appreciated. While the conclusions reached may not be received with una nimous acclaim, we urge that they be accepted in the spint with which they are made.

It goes without saying that our mandate in this exercise was limited to examining the schola rly quality of the public ations and not their substantial content, tenor, faith or ideological leanings 
and/or premises. The report emphasises respect for the independence and freed om of researchers and of the research process itself, as important preconditions for the critic al and innovative production of new knowledge, conceptual frameworks and insights. When, however, the tone of a journal or its contents clearly departed from some of the basic tenets of scholarship, such as the careful citation of sources and the balanced weighing of evidence, or when authors were apparently permitted to use emotive, assertive and/or sectarian a pproaches rather than reasoned discourse, or where there was a relatively frequent inclusion of 'popular' rather than scholarly articles, we have not failed to draw attention to such matters as inadequacies that need to be addressed. In four cases, this regrettably led to recommendations that DHET accreditation for these journals be withdrawn.

The question of the legitimacy of religious studies, theology and the related fields of enquiry and their place in the hierarchy of knowledge will still persist for a long while. Our task is to ensure that standards of rigour and excellence that can hold their own, both on their own terms and those of peers from other disc iplines, as well as the global community of sc holars.

Other than the editors who responded we wish to record our gratitude to the following people:

- The following reviewers for their input:

Prof Tobias Nicklas: Dean - Faculty of Catholic Theology, University of Regensburg, Germany Prof John Kloppenborg: Department for the Study of Religion, University of Toronto, Canada Prof Paul Decock: University of KwaZulu-Natal, South Africa

- The Director: Scholarly Publishing Unit: Mrs Susan Veldsman. The servicing Project Officers, Scholarly Publishing Unit: Mr Thabo Radebe, Mr Zwelibanzi Ndayi and Ms Gugulethu Mtsweni. 


\section{$4 \div=0$ \\ Consensus Reviews of Journals in the Group}

\subsection{Antiquity}

\subsubsection{ACTA PATRISTICA ETBYZANTINA - (New Title: JOURNALOF EARLY CHRISIIAN HISTORY)}

Foc us and Scope: This joumal is published by the Department of New Testament and Early Christian Studies at UNISA, and was also an organ of the South African Association for Patristic and Byzantine Studies. Its aim is to promote Patristic and Byzantine studies. Since the New Testament forms part of the Patristic era, articles on the New Testament are also published.

\section{Editing Func tions: Standing, Local Institutional Spread, Intemational Partic ipation, Peer Review, etc.}

Consensus Review: The current managing ed itor is a relatively young scholar, a lso associated with the publishing department, who took over in 2008-9 from an editor who had occupied the position for 20 years, and who was rated by the NRF as an established researcher. The new editor is considered to be "a respected colleague in the South African context and regularly reads papers at conferences and publishes articles related to this field". The supervising editor, a wellestablished senior scholar in the field, is also from UNISA. The editorial board until recently comprised nine senior academics from South African institutions situated mainly in the northem half of the country (9) and a further nine scholars from foreign institutions (USA 4; Germany 2; Australia 1; Belgium 1); the numbers have now changed to seven local and 17 international scholars. Apart from South Africa, no other country on the African continent is represented. The South African-based members of the editorial board regularly publish articles in the joumal.

Questionnaire: The journal has been published for 20 years without significant intemuptions. In the period of three years under review, the number of manusc ripts received was 78 , while the number of published peer-reviewed original papers was 52 a rtic lesand 11 reviews. None of the manusc ripts was rejected without peer review; two peer reviewers were usually approached for each submitted manuscript, and 42 peer reviewers were used in 2008. Approximately one-third of the published papers had at least one author with a non-South African address, and seven peer reviewers had non-South African addresses. Peer review reports are retained in the records.

The average period between receipt of a manuscript and its publication in print is two months, and on the web, four months. The joumal initially published one volume perannum and in 2011 , it was increased to two issues annually.

The editor was appointed competitively for three years through a selection process. Ed itorial committee members need each to review at least one a ric le every two years, and are informed of the progress of the joumal in an annual report. They a re not appointed competitively, but their a ppointment period is limited to three to four years. They are appointed from inside the country appa rently to pro- 
vide specific topical expertise (See below, for comments on the absence of local focus in the content).

Editorial policy guidelines are published, and a conflict of interest policy is in place. The editorial policy guidelines have been aligned with ASSAf's National Code of Best Practice in Editorial Discretion and Peer Review. Errata are published when the need arises.

The joumal infrequently contains value-adding features, such as editorials, but does publish many book reviews (See below); more rarely, correspondence is published on published articles. Peer-reviewed original material represents $95 \%$ of the pages in each issue.

\section{Content Quality, Focus, Spread within Domain, Sample of Best Work in SA, Enrichment Features, etc.}

Consensus Review: A rea sona ble number of artic les a re published, between 10-15 per annum, published in one issue, until 2010, after which two issues have been published every year. It could be said that these numbers reflect reasonable support by a partic ular sc holarly community which a lso supports two other local journals. This journal probably reflects some of the best work done in South Africa in the fields it covers, while also incorporating a developmental focus in that some recent doctoral graduates have published results from their studies, usually with their supervisors a s co-authors.

The scope of the joumal is declared to be New Testament, Patristic and Late Ancient, and Byzantine studies; studies on the Old Testament and Septuagint, Classics and Religion are also invited. The articles a re generally written in a sound scholarly style, and are well edited, propenly formatted, extensively foot-noted, and fully referenced. Few authors are from outside SA.

The topics covered by artic les are diverse and interesting, although New Testament studies predominate and reflect a local scholarly community in touch with each other. An interesting new development is the public ation of papers related to Septuagint studies, but the relevant papers have tended to go beyond the scope of the journal in that the published articles treat the Septuagint more in the context of Judaism than in that of early Christianity. A special group of articles on the Septuagint was included in the 2009 issue of this journal, together with many other free-standing articles. The new explicit focus of the journal on early Christian history is not apparent from most of the articles published thus far; the articles that do reflect a distinct historical approach to the text (in most cases that of the New Testament), relate to the early Christian context; they represent some of the best work done in the South African context.

It should be noted that two other local joumals, Neotestamenta and Ekklesiatikos Pharos, partially overlap in their interests with this joumal, and cooperation between them may strengthen South Africa's scholarly position/reputation in the international arena, in fields where it is difficult to present a local focus; an even more successful joumal could be established if they were to merge.

The scope of the joumal does not allow for a focus on local materials, as it is focused exclusively on ancient texts and non-South African contexts. Some articles do, however, explic itly set out to present Afric an perspectives.

The joumal attracts only a few artic les from scholars outside the country, including scholars from elsewhere in Afric a who have institutional, personal or educational links with South African universities. It must be noted, however, that the 19 publications with non-South African addresses consist of at least ten book reviews written 
by the same author. The South African authors are drawn from several institutions, but most of them are within the groups which were formerly Afrikaans-medium universities, with no papers coming from other local universities with English-language teaching traditions, and only a few authors are drawn from non-university settings. The joumal should be able to encourage submission of papers from these sources.

\section{Essential Technical Features: English Abstracts, Erata, Citation Practice, Presentation}

Consensus Review: The book reviews are plentiful but, puzzlingly, they have all but one been in German, as a result of which their value is much reduced. In one instance during the period under review, a high number of reviews (10) written by one authorwere published in the same issue. There are, however, no editorials, no correspondence or any othervalue-adding features - this is a pity.

All artic les have proper English abstracts. For the period under review, no errata were published; the editor has indicated that this practice is followed when necessary. The citation practice concurs with intemational standards. Tec hnically the joumal is of a good standard, and the layout is exc ellent.

\section{Usefulness in Capacity Development and Intemational Comparability}

Consensus Review: On the whole it is mostly seasoned scholars who publish in the joumal, and strategies are needed to attract younger researchers.

The joumal appears to provide some good material for both undergraduate and postgraduate use, as exemplars and sources.

Most regional scholarly journals in the field are probably much like this. The spread of artic les across chronological periods covered may, however, be wider than would be found with most such joumals. A grea ternumber of intemational papers would also increase the global impact of the joumal.

\section{Suggested Improvements}

Consensus Review: The editorial board should be broadened to include scholarsfrom institutions in South Africa not yet involved in this journal, and from scholars resident elsewhere in Africa. Contributors should also reflect a much broader representation than is currently the case. There seems to be uncerta inty as to whether the Association for Patristic and Byzantine Studies, mentioned in the editor's report, has in fact been revived; if this can indeed be achieved, the journal could act as a scholarly organ of this society. 'In-breeding' must, however, be avoided, where a small number of scholars read and publish each other's work, without the contributions having any impact in the broader scholarly community.

This journal is edited and produced with care, and contains interesting and significant articles. The partial overlap in focus with Neotestamenta and Ekklesiastikos Pharos needs to be addressed by cooperation, or even consolidation, between them in order to strengthen South Africa's position internationally. (It is not clear whether the imminent name change to J oumal of Early Christian History will disting uish the joumal more form these close a nalogues.) It is very important that articles are solicited from the universities in South Africa which despite having good scholars in the field have not yet contributed to the journal. Deliberate attempts should also be made to involve a wider group of intemational contributors, so as also to attract authors who do not have direct institutional, personal or educational links with South African universities.

The editorial board should function more closely in accordance with the ASSAf guidelines, specifically in respect of the periodic competitive appointment of 
editors and members of the editorial board. The joumal would ga in greatly from presenting opinion-type editorials (some invited), correspondence and otherfeatures; the book reviews should be in a South African language, and preferably written by local academics. The contact details addresses of all corresponding authors must be provided, plus the dates of submission and of acceptance of ind ividual a rtic les.

The number and diversity of book reviews should be increased, and opinion editorials and correspondence introduced.

This joumal needs to be accessible free online to all potential users, as its concems and contributions are of wide interest in the nation. Subject to improvements along the above lines, it should be in the newly established SciELO-South Africa collection, and accredited by the Department of Higher Education and Training in terms of its research outputs policy.

\section{Business Aspects}

The journal's regular print run is only 80 copies per issue, distributed to 34 subscribers of whom 14 are institutional. The publisher is UNISA Press, which holds copyright. Both production and distribution a re outsourced. The joumal cames unpaid advertising effectively subsidised by UNISA Press. No financial sponsorship appears to be received. The journal is part of SABINET's commercial e-publication service, and also part of SA e-Publications, a non-commercial e-publication mechanism. The journal's total income ranges between R25 000-R30 000 per annum, and total expenditure ranges between R15 000-R20 000 per a nnum.

The joumal has not received offers of purc hase from multinational publishers.

The joumal has been reviewed as part of a n extemal departmental review.

The editor would in principle (subject to negotiation with UNISA Press) be interested in being considered for inclusion in ASSAf's SciELO-South Africa open access journal platform.

The joumal has since come under new editorship and will undergo a number of changesas decided by the publisher and the editorial board. The title of the journal will c hange to the J oumal of Early Christian History in order to keep up with the changing trends in the field the journal covers. From 2010, two volumes per annum will be published. Leading figures associated with the journal are in the process of reviving the now-dormant Association for Patristic and Byzantine Studies as a scholarly society supporting the joumal. In 2011, there are plans for initiating a J oumal of Christian History Monograph Series (still in negotiations with UNISA Press) to stimulate and develop scholarship in this field, especially in Southern Africa and the rest of Africa.

\section{Panel's Consensus View}

I. The joumal should continue to be listed on the DHET list of ac c redited joumals.

II. The publisher/ editor should be invited to considerjoining the evolving ScieOSouth Africa platform.

III. The partial overlap in foc us with Neotestamenta and Ekklesiastikos Pharos needs to be addressed by cooperation, or even consolidation, between them in order to strengthen South Africa's position intemationally. (It is not clear whether the imminent name change to J oumal of Early Christian History will distinguish the joumal more from these close analogues.)

IV. The editor/ publisher should seriously consider the consensus recommendations for improvement of the joumal mentioned above, and in particular 
expand the involvement (both as editors and authors) of a larger fraction of the South African community working in the field, and of international scholars.

V. In addition, the Panel believes that the overlap with several other local joumals should be addressed, in order to achieve greater overall impact and enhanced intemational recognition.

\subsubsection{OL TESTAMENTESSAYS (NEW SERIES)}

Foc us and Scope: The joumal publishes a ric les on all a spects of O ld Testament literature, theology, archaeology and society.

\section{Editing Functions: Standing, Local Institutional Spread, Intemational Participation, Peer Review, etc.}

Consensus Review: The editor is internationally well-regarded and is from UNISA, and the associate editors from UNISA, UJ, and NWU. The editorial board, comprising four persons, two more from UNISA, and one each from UP and UKZN, is in fact an oversight body which is the management committee of the Old Testament Society of South Africa (OTSSA). An editorial board, a little confusingly called the advisory board $(A B)$, is drawn by invitation from the OTTSA from senior academics in many countries; two of the members are from Tanzania and Nigeria. The size of the board was increased in 2009 to link the journal to a wider pool of expertise. The sparse information provided makes it difficult to assess the academic status or distinction of the South African editors, although it has been stated that the editorial board members are top South African Old Testament scholars. The AB members camy out peer reviews and adjudicate when other peer reviewers differ markedly in opinion on a particular article (See below). Whilst there are clearly too many editors from one institution, UNISA, this university does have the largest department in this subject in the world.

Questionnaire: Old Testament Essays started in 1983 within the Department of Old Testament at UNISA. In 1988, ownership was transferred to the Old Testament Society of South Africa, and the journal was given its present name of Old Testament Essays (New Series), which hasnow appeared for the past 22 years. During the period from 2006-2008, the number of published original items was 159 articles (selected from about 180 manuscripts submitted), and no fewer than 62 book reviews. No manuscript was rejected without peer review; $10-15 \%$ of manuscripts are rejected after review, with $80 \%$ being referred back for revision and re-working. Thus only $5-10 \%$ manuscripts are accepted without any changes.

About $33 \%$ of published papers had at least one author with a non-South African address. Usually two peer reviewers are approached per submitted manusc nipt but, in some cases, a third will become involved for purposes of arbitration. In 2008, 50 people peer-reviewed about 55 articles, most reading two articles and in some instances, three articles. About $10 \%$ of the peer reviewers had non-South Afric an addresses.

Peer-review reports are accessibly retained in records (it took a while to create a workable administrative system, including a peer adjudication form that works. Old Testament Essays does not have an administrative officer working permanently or an office located at a university; the administration is accordingly done by the editor and associate editors, with someone else doing the accounts and posting.

The average interval between receipt of a manuscript and its public ation in print is variable, usually over three months, because very few articles are accepted without any change.

The joumal is not yet available on the web. 
The joumal is published three times a year. There once were supplement series, but their production was too costly and it was stopped. The joumal issues a re not prescheduled to appear on given dates, but the first issue usually appears in May/ $\mathrm{J}$ une, the second issue in October/November after the annual meeting of the OTSSA in August/September, and the third issue is put together in December for publication at the end of the following January. No issue has ever been skipped.

The present editor, who has been editing the joumal for only one year, was appointed non-competitively for three years at the annual general meeting (AGM) for a three-year period as per the constitution. The selection process consisted of a vote by the association members on the names submitted of willing candidates.

As a lready stated above, the members of the editorial board are the executive of the OTSSA, the owner of the journal. They need to give permission for any major changes in the joumal. The peer-reviewing process is handled as follows by an associate editor: The editor receives and records the submissions, which a re then sent to the associate editor, who distributes the submissions for blind peerreviewing and handles the review reports before making recommendations on acceptance or rejection to the editor.

Most articles need to be reworked. Members of the advisory board are tasked to assist with the peer-reviewing of a rticles submitted for public ation, to adjudic a te an article when the initial peer-reviewing results in contrasting evaluations, to review each volume in terms of academic quality and scientific nature of published articles, and to assist in building the international profile of the journal.

Members of the editorial board also give advice on editorial polic ies and practices, but the entire OTSSA at its AGM must consent to significant changes, such as style, membership of the advisory board, and mode of publication (web, print or both). The advisory board is tasked to oversee the quality of the journal.

Editorial policy guidelines are published on the first pages of each issue; they have not formally been aligned with ASSAf's National Code of Best Practice in Editorial Disc retion and Peer Review.

Errata are published when the need arises.

\section{Content Quality, Focus, Spread within Domain, Sample of Best Work in SA, Enric hment Features, etc.}

Consensus Review: The articles are generally written in a sound scholarly style, and are propenly formatted, extensively foot-noted, and fully referenced. This reflects the rigour employed in peer review. A few authors are from outside South Afric a, and a few artic les are written in an Afric an language. The Old Testament topics covered are diverse and challenging, and reflect a local scholarly community in touch with each other.

There are over 40 artic les per annum, published in three issues. The large number of artic les is understandable in tems of the extensive scholarly community orga nised as the Old Testament Society in Southern Africa embracing no fewer than three major fa iths, and the traditional prominence of theological faculties in the country catering for the diverse denominationsconcemed.

The foc us of the joumal and the large scholarly community of local authors (and presumably readers) mean that the published work represents a significant part of what could be produced in the country.

A focus on local or regional kinds of materials is not really applicable, but a few articles do display such a focus. The local authors are drawn from a spread of 
institutions, with a clear predominance of the institutions formenly associa ted with Afrikaans-medium instruction; there are no papers from the University of Cape Town (UCT), the University of the Witwatersrand (Wits) or Rhodes University (RU), only a very few from the University of KwaZulu-Natal (UKZN), and few or nothing from historically black universities. A reasonable proportion of authors is drawn from outside the country, perhaps as much as one-third.

\section{Essential Technical Features: English Abstracts, Enata, Citation Practice, Presentation}

Consensus Review: There are a few book reviews in most issues, some in German, and they add value to the journal's pages. There are, however, no 'opinion editorials', and a limited correspondence, and no other value-adding features - this is a pity.

Good and suitable English abstracts for each article are provided. Several publications of errata were noted. There is a sound, consistent, and appropria te citation practice throughout. The layout is good and readable.

\section{Usefulness in Capacity Development and Intemational Comparability}

Consensus Review: The joumal provid es some good materia I for both undergraduate and postgraduate use, as exemplars and sources. A special interest in South Africa/ Africa is not displayed. The joumal compares well with Vetus Testamentum, and the Zeitsc hrift für die Alttestamentlic he Wissensc haft.

\section{Suggested Improvements}

Consensus Review: This joumal is edited and produced with care, and contains interesting and significant articles. The spread of contributing universities needs to be widened considerably, and efforts must be made to widen participation in the editing and peer-reviewing functions also. The dates of submission and acceptance should be indicated for each article.

It is very important that the editorial board functions according to the ASSAf guidelines, specifically with respect to the periodic competitive appointment of editors and members of the editorial board. The advisory board should be called the editorial board and the present body of that name renamed.

The joumal would gain greatly from presenting opinion-type editorials (some invited), correspondence and other features.

This joumal needs to be accessible free online to all potential users, as its concems and contributions are of some interest in the nation.

\section{Business Aspects}

The regular print run of the journal is 375 copies; it is published by the Old Testament Society of South Africa. Printing is outsourced. The rest of the work is done by the editor, the associate editors and the administrative assistant. The joumal carries neither paid nor unpaid advertising. It also does not receive any financial sponsorship.

The total number of subscribers is: members: 179 (35 honorary and 144 paying); libraries: 109 outside South Africa and 21 inside South Africa. Despite its wish to become free online, the joumal for reasons of necessary income uses the servic es of SABINET Online as part of the latter's commercial e-publication service. The journal's total income perannum is R194 000, while the total expenditure is R120 000 . 
The joumal is indexed in Americ an Theologic al Library Association (ATLA) and Old Testament Abstracts. The joumal has never received offers to purcha se from multinational publishers. Copyright resides with the authors. English abstracts and front details a re published for all artic les. A decision is imminent on whether an invitation to join the ASSAf SciELO-South Africa open access platform will be accepted.

\section{Panel's Consensus View \\ I. The joumal should continue to be listed on the DHETlist of acc redited joumals. II. The publisher/editor should be invited to join the evolving SciElO-South Africa platform. \\ III. The editor should seriously consider the comments and recommendations made in this review, partic ularly those aimed at the improvement of an already strong joumal.}

\subsection{3}

\section{NEOTESTAMENICA:J OURNALOFTHENEWTESTAMENTSOCIETY OFSOUTHARICA (NISSA)}

Foc us and Scope: Neotestamentica publishes articles on all aspects of the New Testament, ranging from historic al to hemeneutic al and methodologic al studies.

\section{Editing Functions: Standing, Local Institutional Spread, Intemational Participation, Peer Review, etc.}

Consensus Review: The editor, who was rated by the National Research Foundation (NRF) as an intemationally acclaimed researcher, is a highly respected academic from UKZN, and the review editor is from the University of Pretoria (UP). The institutional addresses of the eight members of the editorial board are not provided, nor are those of the similar number of members of the intemational advisory board (IAB); this makes it difficult to assess their institutional affiliations, academic status or distinction. It is believed that the editorial board reflects persons from institutions around the country, and that the IAB comprises mostly scholars internationally well-known in the field, but few or none seem to be from the rest of Afric a or Asia. The role of the AIB members in running the joumal is not explained. It further appears that both boards underwent changes during the period under review, which is positive as it assures that the joumal represents a broad scholarly community.

Questionnaire: The journal has been published for 42 years, without significant interruptions. For the three-year period 2006-2008, the number of published original articles was 47 and book reviews 71; In the same period 81 article manuscripts were received (acceptance rate of just under $60 \%$ ). No manusc ript was rejected without peer review. Eighteen out of 47 articles, and five out of 71 reviews had at least one author with a non-South African address. Two to three peer reviewers are usually approached for each submitted manuscript. In 2008, 48 peer reviewers were used, of whom nine had non-South African addresses. All peer-review reports are retained in the records.

The average interval between receipt of a manuscript and its public ation in print is three to four months. The public ation frequency of the joumal is two issues per year; these are not pre-scheduled to appear on given dates.

The present editor, who has been running the joumal for six years, was not appointed competitively but was through election for a four-year fixed term (renewable) at the annual general meeting of the academic society concemed (New Testament Society of South Africa(NTSSA)). Members of the editorial board are also not appointed competitively, since it consists of the elected office-bearers of the executive of the NTSSA, together with former editors. Their period of appointment is not specified. Some editorial board members do handle peer reviews of individual manuscripts, and advise on editorial polic ies and practices. 
The editorial board consists of members from inside the country, but there is an intemational a dvisory board chosen by the editorial board consisting of scholars from outside South Africa. The members of the IAB are chosen for their specific topical expertise.

Editorial policy guidelines are published, and the journal has a conflict of interest policy although it has not been captured in writing. The editorial polic y guidelines have been aligned with ASSAf's National Code of Best Practice in Editorial Discretion and Peer Review. When it is necessary, errata are published. The joumal contains editorials, and, when pertinent, topical reviews; many book reviews (See above) but not, as a rule, correspondence on published articles. The percentage of pages in each issue that represents original peer-reviewed material is $100 \%$.

\section{Content Quality, Foc us, Spread within Domain, Sample of Best Work in SA, Ennichment Features, etc.}

Consensus Review: The artic lesa re genera lly written in a sound sc hola rly style, and are properly formatted, extensively foot-noted, and fully referenced. Since the field of New Testament studies is quite broad, contributions cover a wide range of topics related to the field. About half the authors are from outside South Africa, ma inly from North America and Europe, and not from Africa: in most cases the international contributors are in some way also linked to a South African tertiary institution. The artic les from inside the country a re contributed mainly by tertiary institutions with faculties or sc hools of theology from all over the country, with institutions with larger faculties or sc hoo ls of theology necessa rily better represented. New Testament topics covered are diverse and challenging, and reflect a local scholarly community in touch with each other. It should be noted that two other local joumals, Acta Patristica et Byzantina (shortly to be re-named J oumal of Early Christian History) and Ekklesiastikos Pha ros partially overlap in their interests with Neotestamentica, and cooperation, or even consolidation between them, may strengthen South Africa's scholarly position/reputation in the international arena, in fields where it is difficult to present a local focus.

There are between 13 and 15 artic les perannum, published in two issues. One of the issues was a special, guest-edited centenary volume for the University of Pretoria. The small number of artic les is understandable in terms of a small scholarly community organised as the New Testament Society of South Africa, but it must remembered that two other local joumals also cater for articles in this general field.

The focus of the joumal and the small scholarly community of local authors (and presumably readers) make it likely that the published work represents a significant part of what could be produced in the country. The joumal under review commendably attracts a $n$ a p preciable part of its material from foreign authors. It could be said that the journal is the flagship for New Testament research in South Afric a, both in tems of the spectrum of articles across the discipline, as well as the qua lity of artic les published. Although most artic les deal with issues that New Testament sc holars all over the world are interested in, on average of at least one to two articles per annum focuses on local issues; these articles usually come from the subfield of hermeneutics.

The small number of SA authors is drawn from several institutions, with several authors drawn from outside the country.

\section{Essential Technical Features: English Abstracts, Erata, Citation Practice, Presentation}

Consensus Review: The book reviews are plentiful and excellent (about 15-20 per annum) and add much value to the journal's pages. There are, however, no 
editoria Is (excepting in special volumes), no correspondence or any other valueadding features - this is a pity.

All articles have proper English abstracts. No errata were noted. There is good, consistent, complete and appropriate citation practice throughout. The layout is adequate to good.

\section{Usefulness in Capacity Development and Intemational Comparability}

Consensus Review: Although the joumal attracts artic les from some leading scholars it also publishes artic les from a younger generation of (local) scholars, in this way stimulating on-going research in the field. The journal provides some good material for both undergraduate and postgraduate use, as exemplars and sources.

It is difficult to compare local journals, such as this one, to leading international joumals which have become intemationally acclaimed over many decades. These receive so many manuscripts for publication that they can be extremely selective as to what gets published. At least two to four artic les per annum published in Neotestamentica rate on a par with articles published in leading international journals in the field. It provides a good overview of a wide spectrum of approaches in New Testament research, and is not committed to any provincial or local approach or trend.

\section{Suggested Improvements}

Consensus Review: This joumal is edited and produced with care, and contains interesting and significant articles. The partial overlap in focus with Acta Patristica et Byzantina (shortly to become the J oumal of Ea rly Christian History) and Ekklesiastikos Pha ros needs to be addressed by cooperation, or even consolidation, between them in order to strengthen South Africa's position internationally. The editorial board could consider attracting more scholars from the African continent to publish their results in this joumal. If at least one of the intemational contributors per numbercan be from elsewhere in Afric a the joumal will render an even better service to the scholarly community on the continent. The leamed society that publishes this joumal comprises a number of leading New Testament sc holars and NRF-rated researchers, who could be requested to support this joumal by means of regular contributions (some leading South African scholars in the field did not publish in this joumal during the period under review).

It is very important that the editorial board functions more closely according to the ASSAf guidelines, specifically in respect of the periodic appointment of editors and members of the editorial board. The involvement of the IAB should be explained/extended.

The joumal would gain greatly from presenting opinion-type editorials (some invited), correspondence and other features. Some form of internal debate/scholarly discussion within the journal could improve its quality, like a discussion forum or critical review where dialogue takes place between scholars. Alternatively, there could be a critical review of a book where the latter's author has the opportunity to respond in the same volume.

The full addresses of all editors, editorial board members and authors must be provided, plus the dates of submission and of acceptance of individual artic les. This joumal needs to be accessible free online to all potential users, as itsconcems and contributions are of wide interest in the nation. 


\section{Business Aspects}

The journal's regular print run is 500 copies; it is published by Neotestamentica, part of the New Testament Society of Southern Africa. Production is outsourced but distribution is handled in-house. The joumal does not camy either paid or unpaid advertising, nor does it receive financial sponsorship.

The number of subscribers is 153 NTSSA members and 222 additional paying subscribers; organisations are 193 of the latter.

The joumal is not free online (open access). Some of the articles from each issue are available free online, however. The journal's total income per year is about R115 000 and the total expenditure is about R110 000. The joumal has never received offers to purchase from multinational publishers. Copyright belongs to the joumal.

English abstractsare published for a ll articles. The jouma I has never been independently peer-reviewed before, although a full retum was submitted to the Department of Education Accreditation Policy Study of 2005. The idea of the journal's possible inclusion in the ASSAf SciELO-South Africa platform is still under discussion by the editorial board.

\section{Panel's Consensus View}

I. The joumal should continue to be listed on the DHET list of acc redited joumals. II. The publisher/ editorshould be invited to considerjoining the evolving ScieOSouth Africa platform.

III. The editor should seriously consider the recommendations for improvement presented in this consensus review.

IV. In addition, the Panel believes that the joumal should disc uss cooperation with two other local journals in this general field, Acta Patristica et Byzantina (shortly to be re-named J oumal of Early Christian History) and Ekklesiastikos Pharos.

\subsubsection{JOURNAL FOR SEMITIC S/TYDSKRIF VIR SEMITISIIEK}

Foc us and Scope: The J oumal for Semitic s is published by the Southern African Society for Near Eastern Studies (SASNES). (An observer may well question the relationship between 'semitic' and 'near Eastern' studies, without further qualification of the historical period concern - See below). The journal is published twice a nnually.

Editing Functions: Standing, Local Institutional Spread, Intemational Partic ipation, Peer Review, etc.

Consensus Review: The editor is from UNISA's Department of Old Testament and Ancient Near Eastern Studies, while the institutional association of the assistant editor is not specified. While the journal's title, however, is bilingual, all six members of the editorial committee are senior academics from universities in SA that formerly used predominantly Afrikaans as their medium of instruction. It seems that no/few academic s partic ipa te from universities a lso offering religious studies/ theology courses but not falling into this group, which makes this a problem of editorial distribution and possibly, focus. The intemational a dvisory boa rd comprises nine ind ividual a cademics from other countries in Africa, the near East and elsewhere; its members are occasionally requested to act as referees, but their primary function is to comment on three questions every year after the completion of a volume:

- Were the contents of the volume, as far as articles in the requisite field of expertise are concerned, at a satisfactory standard? 
Can the journal be recommended for subscription to a colleague or library?

- Mention of any aspect of particular concem, positive or negative, for the attention of the editors.

Questionnaire: The joumal has been published for 20 years. Public ation fell behind between 1997 and 2001, but the joumal eventually a ppeared as Volumes 9 (1\&2) and 10 (1\&2) - the latter during 2001. In the period under review (2006-2008), 97 original artic les were published, from 107 manusc ripts received, an acceptance rate of over $90 \%$. None of the manuscripts received was rejected without peer review. Approximately $20 \%$ of published papers had at least one author with a non-South African address.

At least two peer reviewers a re usually approached per submitted manuscript, and 55 reviewers were used in one year. Less than $10 \%$ had non-South African addresses. Peer-review reports a re accessibly retained in records. The average interval between receipt of a manuscript and its public ation in print is ten months, and the same for e-publication through SABINET. The journal publishes two issues peryear, in J une and November.

The editor, who has been editing the joumal for six years, was appointed through elections at the annual meeting of the SASNES, but for an unspecified period. Members of the editorial board, who constitute the exec utive committee of the society, are also elected at the AGM, each for a three-year period. They handle peer reviews of individual manusc ripts, and give advice on ed itorial polic iesand practices, as members of the society. They comprise members from inside and outside South Africa, in order "to be representative of Southern African universities and academics" (Constitution of SASNES). They are appointed to represent different fields of specialisation and different universities.

While editorial policy guidelines are published, there is no conflict of interest policy. The editorial policy guidelines have been aligned with ASSAf's National Code of Best Practice in Editorial Disc retion and PeerReview. Errata a re published when errors have become apparent. The joumal publishes editoria ls only when an issue is dedicated to a colleague. Correspondence on published articles is published as value-adding feature. The percentage of pages in each issue that represents peer-reviewed original material is nearly $100 \%$.

\section{Content Quality, Focus, Spread within Domain, Sample of Best Work in SA, Enric hment Features, etc.}

Consensus Review: Semitics is widely and logically defined as "the study of Semitic languages and culture"; this does not specify a pre-occupation with ancient times, the Bible or the Qur'an. Yet the editor claims that "semitics and near Eastern studies are traditionally linked with the ancient semitic languages and cultures". It is also said that "modern issues related to Jewish, Christian and Muslim readings of the Tenakh, Bible and Q ur' an, as well a sissues of cultural value to these faith communities, are published in the journal". Despite this, most of the articles in each issue of this obviously well-supported joumal do have a pre-occupation with ancient times, and the exceptions immediately strike the reader with the feeling of many opportunities missed. It is likely that the primary professional training function of theological faculties in South African universities has contributed to departments supplying service courses and producing scholarship of a particular kind, appearing in a well edited and supported journal like this one. That means that the outside academic may well be puzzled why an area as potentially vibrant and contemporary as Semitics should retain its 'old' pre-occupations with matters that engaged scholars in past times but do not appear to address the serious contemporary issues in the field. 
That sa id, the articles in this joumal are variable in quality, mostly good, but some in the category of 'popular', and some whose pertinence to the journal is dubious. The artic lesare generally carefully edited and proofread, and readable in nature. A small number of the articles are rightly Africa-focused. Most are 'free-standing', and the editors are succeeding in attracting a flow of good articles that allows them to a void having to resort to symposia or special issues in order to attract a ric les. There is much to be leamt from the topics covered, from reading the artic les or their abstracts, but there is surely much more in the post-antiquity phases of the field that one would like to see rigorously explored, taking into account the importance of the near East in the post-ancient and modem world, and the many and deep issues raised by so many fascinating and significant historical epochs affecting, or brought about by, the Semitic peoples. In fact, reading most of the papers gives one the impression that time is somehow assumed to have stood still, or nearly so, in many contexts of society, political conflict, and insights into the human condition.

There are between 35-40 artic les perannum, published in two issues. This is impressive in local-journal terms, and reflective of a community of scholarship that has reached critical mass, and can make their journal serve important roles in promoting ideas and collaborations.

The historical origins of the journal as associated with a largely Afrikaans-speaking community, plus the present narrow focus of the journal on Semitics in the ancient world, permits the conclusion that there is much that could be published in this joumal that is not yet included, both in terms of historic al epochs ba rely covered and local academic s not participating. Widening the historic al span and the distribution of scholarly endeavours will surely elic it many more articles from active authors in many fields.

The authors are drawn from several, but not all SA institutions, with a few from outside the country (See above for skewing effects).

\section{Essential Technical Features: English Abstracts, Enata, Citation Practice, Presentation}

Consensus Review: There are no book reviews, no opinion editorials, no correspondence or any othervalue-adding features. This is a pity in such an apparently vigorously publishing community.

English abstracts for all articles are included. No errata were noted in the issues reviewed. The citation practice is good, consistent, and complete throughout. The layout is exc ellent.

\section{Usefulness in Capacity Development and Intemational Comparability}

Consensus Review: In many ways the joumal provides good material for both undergraduate and postgraduate use, as exemplars and sources. Widening the scope of artic les in tems of authorship and scope will enhance this, as discussed above.

Most regional scholarly journals in this field are probably much like this, but presumably those that embrace modemity are much more substantial. The volume of articles and their generally high quality makes this a significant national journal, although in a too na row context. It doesnot compa re with jouma ls such the J ournal of Semitic Studies, the Review Semitique Vetus Testamentum, and the J oumal of the Americ an Oriental Society, which a re all top-tier intemationally.

\section{Suggested Improvements}

Consensus Review: This joumal is edited and produced with care, and contains interesting and significant articles within its present limited remit. It is very important 
that (i) the spread of editorial board members and article authors be extended throughout the country's institutions and internationally; (ii) the disciplinary focus of the journal be widened, preferably to include more papers dealing with Semitics of post-ancient periods, including the present; (iii) all faith-based content is carefully analysed and excised or rejected if necessary; (iv) the editorial board also functions more closely according to the ASSAf guidelines, specifically in respect of the periodic appointment of editors and members of the editorial board; and $(v)$ the peer-review mechanism is reviewed in order to ensure better quality control (the acceptance rate if far too high). The joumal would gain greatly from presenting opinion-type editorials (some invited), book reviews, correspondence and other features. The full contact deta ils of corresponding a uthors must be provided, plus the dates of submission and of acceptance.

This jouma I needs to be accessible free online to all potential users, as its concems and contributions are of wide interest.

\section{Business Aspects}

The regular print run of the journal is 200 copies, and it is published by the Southern African Society for Near Eastern Studies (SASNES). Production is done by UNISA Press, while distribution is done intemally. The joumal does not camy either paid or unpa id advertising. The journal receives financial sponsorship; UNISA Press contributes substantially to the production and mailing costs.

The joumal has 132 paying subscribers, of whom 32 are libraries as opposed to individuals. The journal appears online as part of SABINET's commercial (pay-toview and/or pay-to-subscribe) e-publication service. The journal's total income is a bout R51 000 over three years, while total expend iture is a bout R36 000, a lso over three years.

The joumal has in the past rec eived offers to purchase from multinational publishers. Copyright resides with the journal/society. The journal is indexed in Old Testament Abstracts. English abstractsand front deta ils a re published for all a rtic les. The joumal was previously independently peer-reviewed. In principle, the society is interested to join the ASSAf SciELO-South Africa open access platform.

\section{Panel's Consensus View}

I. The joumal should continue to be listed on the DHET list of acc redited joumals.

II. The publisher/ editor should only be invited to consider joining the evolving Sciel-South Africa platform, when the implementation of the improvements recommended in the review has been completed.

III. The editor should in any case seriously consider these improvements, in partic ular the widening of the scope and reach of the joumal, the tightening of quality assurance though more rigorous peer review, betterappointment procedures for the editor and editorial board, and the inclusion of value-adding features.

\subsubsection{EKKIESASTIKOS PHAROS}

Focus and Scope: Ekklesiastikos Pharos was originally published in Alexandria (Egypt) directly by the Greek Orthodox Patriarchate as a theological review at the beginning of the 20th Century. Consequently E. Pharos is one of the oldest scholarly periodicals in Africa. The periodical later moved to Athens, but since 1990 the African edition, now known as Ekklesiastikos Pha ros (New Series) is ed ited aga in in Africa (J ohannesburg/Alexandria) - under the auspices of the Orthodox Patriarch of Alexandria - by the Institute for Afro-Hellenic Studies (in Johannesburg), at present with the collaboration of the Department of Greek and Latin Studies of the University of Johannesburg. The new series of the periodical is a theological, as well as philologic al-humanistic joumal, a lso publishing research on Modern Greece, Byzantina and Afro-Byzantina. 


\section{Editing Functions: Standing, Local Institutional Spread, Intemational Partic ipation, Peer Review, etc.}

Consensus Review: The joumal is a theologic a l and huma nistic-philolog ic a I review of the Greek Orthodox Patriarchate of Alexandria (Egypt), and is published by the Institute for Afro-Hellenic Studies (IAHS) in collaboration with the Department of Greek and Latin Studies of the University of Johannesburg (UJ). It is edited by the Greek Orthodox Archbishop of Johannesburg and Pretoria, and by two NRF-rated academics in the latter UJ department, Prof B Hendrickx (rating B) and his wife, Dr Thekla Sansaridou-Hendrickx (rating C) The editorial board has 16 members, of whom eight are from South Africa (three more from UJ, two each from UP and TUT, and one from NWU); the other members are from Greece (6), Kenya and the DRC (one each). They are all professors and/have doctorates. From information provided by the editor, they appear to have substantial scholarly reputations in the wide span of areasincluded in the scope of the joumal.

Questionnaire: The journal has been published without significant interruptions for over 90 years - one of the oldest scientific periodicals in Africa (and was as such recognised by an award of the Academy of Greece). In the period under review, 73 original artic les and eight reviews were published, drawn from 110 ma nuscripts received. Approximately a tenth of the manuscripts received were rejected without peer review. About a quarter of the published papers had at least one author with a non-South African address. Two peer reviewers are usually approached for each submitted manuscript; about 25 reviewers, two thirds with non-South African addresses, were used in one year. For the last three years, reports have been retained in records in both Johannesburg and Thessaloniki, with the Greek Patriarch also retaining his own. The IAHS and the Patriarchate consider these archives as confidential, but are prepared to open them for the benefit of scholarship in South Africa.

The average interval between receipt of a manuscript and its publication in print is between seven and 12 months. The joumal is published only once peryear, and appears on a pre-scheduled date.

The editor has occupied this position for 20 years, but was re-appointed on merit but non-competitively at least four times in that period by the Patriarch and his Council (subdivision: Science and Scholarship), The periodical belongs to the Greek Orthodox Patriarchate of Alexandria, Egypt.

The members of the editorial board, drawn from both inside and outside South Africa, are not appointed following a formal competitive selection process, but are invited to serve in respect of particular sub-fields for ten years at a time. They handle peer reviews of individual manuscripts, especially the foreign ones, and give advice on editorial polic ies and practices.

Editorial policy guidelines a re published. These have been partially a ligned with ASSAf's National Code of Best Practice in Editorial Discretion and Peer Review, more attention being given to European guidelines applied especially to this field. Errata a re published where errors have become apparent. The joumal sometimes publishes editorials; in the past, there have been occasional news and views, but in 2009 a section on 'Documents, Discussions and Notices' was introduced. Book reviews a re also published as value-adding features. The percentage of pages in each issue that represents peer-reviewed original material is 80 to $90 \%$.

\section{Content Quality, Foc us, Spread within Domain, Sample of Best Work in SA, Enrich- ment Features, etc.}

Consensus Review: A substantial fraction of the articles are written in Greek and could not be assessed by the reviewers. The others cover a wide range of matter 
related to theologic al and religious-studies a spects of this church, with its long history and varied roles and fortunes, in Afric a as well as other regions of interest to it. There is a vast preponderance (and repeated appearances) of authors from UJ, and, to a much lesser extent, UP and NWU. The articles are of highly variable quality, mostly rather poor, and often exhibit distinct features of "crawling with a hand-lens at the frontier of knowledge". One needs to know the extent of the involvement of the editorial board as opposed to multiple independent reviewers, the sta tistic s of outcomes of submissions to this joumal, and other expla nations as to how so many articles are published in/from South Africa in such a highly restricted field, in which partial overlaps also exist with at least two other quite substantial joumals, Neotestamentic a and Acta Patristica et Byzantina (the latter soon to be re-named J oumal of Early Christian History). The fact that the joumal is accredited for research-output subsidies by the DHET means that the publication generates a large annual income for its parent institution - this is a 'red flag' for further investigation.

There have been between 20-25 articles per annum, published in one volume. Many are in Greek, but the English/Afrikaans articles number about 10-15. This relatively large number of articles is remarkable, and seems to reflect good and continuing support by a particular scholarly community (See above). The number of book reviews is about two to five per volume.

The productivity of this joumal, and that of the similar jouma ls mentioned above, means that there is an unexpectedly large scholarly community of local a uthors (and presumably readers) in what is really a restricted field of scholarship in South Afric an terms.

A few of the articlesdisplay a local and contemporary focus, but most a re gazing through a more distantly foc used mirror.

As stated above, the authors are repeatedly listed as coming from UJ, UP and NWU, if they are not from Greece. Very few articles are authored by scholars at UCT, Wits, UKZN, Rhodes, the Nelson Mandela Metropolitan University (NMMU), Fort Hare University (FHU), or other local institutions. Very few authors come from departments not located in theology/religious studies, although some do come from history departments. The large va riety of other disc iplines in many institutions with a potential interest in the field of focus of Ekklesiastikos Pharos are not (yet) participating in the life of this journal, which seems to be more of a 'closed shop' than an open forum of modem scholarship.

\section{Essential Tec hnical Features: English Abstracts, Erata, Citation Practice, Presentation}

Consensus Review: There are a few book reviews, but no 'opinion' editorials, no correspondence, or any othervalue-adding features. This is a pity. The introductory sections of articles labelled 'Abstract' are too short to be proper abstracts in a literature subject to metadata formation and searching on the intemet.

No publication of errata was noted. The citation practice is reasonable, and follows appropriate practice, apart from inconsistent use of footnotes and a lot of out-of-date references. The layout is a dequate to good.

\section{Usefulness in Capacity Development and Intemational Comparability}

Consensus Review: The generally 'closed shop' tone of the journal and the poor quality of many artic les would preclude its usefulness in most academic settings. It would be important to know how much notice is taken of this journal in Greece. 
The purported 'international' nature of the journal is contradicted by the fact that it is not very good by 'national standards'.

\section{Suggested Improvements}

Consensus Review: This joumal appears to be rather closed to scholars outside a particular community, apart from the matters about which other preliminary comments have been made in previous sec tions. The foc us partia lly overlaps with those of two other SA journals, Neotestamentica and Acta Patristic a et Byzantina (soon to be re-named J oumal of Early Christian History). The field is generating an enomous number of articles every year, many of them authored by the same group of people from the same group of institutions. It is important that the editors of the three joumals meet to discuss possible cooperation and rationalisation, plus agreeing to a set of audits to illuminate the effectiveness of peer review and quality assurance generally. The failure to connect with scholars working in related ma instream disciplines is to be deplored.

Apart from these organisational points, in the short term it would also be very important that a rtic les are solic ited from universities and departments which, despite having good scholars in the field, have not yet contributed to the journal. The editorial board should function more closely in accordance with the ASSAf guidelines, specifically in respect of the periodic appointment of editors and members of the editorial board. Peer review should be strengthened through a greater diversity of independent reviewers. The joumal would ga in greatly from presenting opinion-type editorials (some invited), comespondence and other fea tures. The dates of submission and of acceptance of individual articles should also be provided.

Recommendations on possible accession to SciELO-SA or accreditation by the DHET would need to follow further review of possible actions taken by the editors in connection with the kinds of rationalisation and quality improvement suggested above, before accession to the SciELO-South Africa collection could be considered, nor should accreditation yet be granted by the Department of Higher Education and Training in terms of its research outputs policy.

\section{Business Aspects}

The regular print of the journal is 250 copies per issue. The publisher is the AHS, based in Johannesburg and Thessaloniki, Greece (under patronage of the Greek Orthodox Patria rc hate of Alexandria, Egypt) in collaboration with the Department of Greek and Latin Studies of the University of Johannesburg. Preparative work is done in RSA and partly in Greece, since the IAHS operates in South Africa, as well as in Greece, and has two headquarters. Both production and distribution a re partly outsourced. The joumal does not camy paid advertising, but sometimes publishes unpaid advertising related only to research. The joumal receives partial financial sponsorship.

The paying subscribers are members of IAHS (in Greece or RSA) or organisations a s opposed to individuals. All costs (total expenditure between R 17000 - R23 000) are covered by subscriptions, page money and donations. Shortfalls are met from IAHS funds and a fund in the Department of Greek and Latin Studies at UJ.

The joumal has never received offers to purchase from multinational publishers, but some Greek academic publishers are interested, and negotiations to this end are under way. Copyright is established via the UJ library.

English abstracts and front details are published for all articles. The joumal was previously independently peer-reviewed overseas, in Belgium and Greece. An 
invitation to join the ASSAf SciELO-South Africa open access platform would be considered and discussed.

\section{Panel's Consensus View}

I. The case for this joumal being listed in the list of joumals accredited by the DHET is not strong; we recommend that it not be included in the list for the time being.

II. The publisher/ editor should also notyet be invited to join the evolving SciEOSouth Africa platform, as the cument joumal is not considered to be of high quality and there are serious questions about its scholarly operation.

III. The editor should accordingly seriously consider the criticisms and recommendations listed above, whic $h$ each require detailed responses and remedial action.

IV. In addition, the Panel believes that the joumal must interact with the editors/ publishers of two other SA joumals, Neotestamentica and Acta Patristica et Byzantina (soon to be re-named J oumal of Early Christian History) in order to strengthen South African scholarship in this broad field.

\subsection{Mainstream Theology}

\subsubsection{ACTA THEOLOGICA}

Focus and Scope: Acta Theologica is a DHET-accredited South African journal publishing independently refereed research in the Biblical sciences, theology, and science of religion. Articles are published in English, Afrikaans, and occasionally in Dutch and German.

Editing Functions: Standing, Local Institutional Spread, Intemational Participation, Peer Review, etc.

Consensus Review: The members of the editorial board are drawn from South Africa and Europe, but only one editor comes from the rest of Africa and there are no members from Asia. The members of the ed itorial board a re generally rega rded as having good national and intemational standing in the disc ipline concemed. Both the former and present editor are respected scholars in their fields.

Questionnaire: The journal has been published for 29 years without significant interruptions. In the period under review, the number of published peer-reviewed oniginal papers was 92 articles and 24 reviews, drawn from 152 submissions received; few manusc ripts were rejected without peer review. Approximately $20 \%$ of the published papers/reviews had at least one author with a non-South African address. Two peer reviewers are usually approached for each submitted manusc ript, and altogether 64 peer reviewers were used in the same period; none of them had a non-South African address. Peer-review reports are retained in records.

The average interval between receipt of a manuscript and its public ation in print has been six monthsto one year, and on the web about the same. The publication frequency of the joumal is twice peryear, plus at least one supplement perannum. The regularissues of the joumal are pre-scheduled to appear in J une and December of each year.

The present editor has been in the position for only five months, after competitive appointment through a selection process, for an unspecified period. Members of the editorial board handle peer reviews of individual ma nuscripts, and sometimes act as arbitration reviewers. They also advise on editorial policies and practices. The members a re not appointed competitively via advertisement, and no specific period is given for their a ppointment. They a re appointed from inside the country in order to provide specific topical expertise (they are from different disciplines within theology). 
Editorial policy guidelines are published; a conflict of interest policy is (puzzlingly) considered not applicable in theology. Apart from this, the editorial policy guidelines have been aligned with ASSAf's National Code of Best Practice in Editorial Disc retion and Peer Review. Errata are published when the need arises. The joumal contains a limited number of book reviews as a value-adding feature. The percentage of pages in each issue that represents peer-reviewed orig inal material is $99 \%$.

\section{Content Quality, Focus, Spread within Domain, Sample of Best Work in SA, Enric hment Features, etc.}

Consensus Review: Although there a re some exceptions, the qua lity of the articles accepted and published (mostly in Afrikaans) is generally average to good. While most of the articles are from South African authors, these are not evenly drawn from across the country, although they are certa inly distributed more widely than from just the host institution where the journal originates. Some authors are not from theological disciplines, but from related fields.

While the artic lespublished are adequate in number, they cannot be described as a significant sample of the best theological work done in the country, since most of the leading names in the different theological disciplines have not published in the joumal over the last three years. The joumal provides an opportunity for lesserknown scholars, research assistants and postgraduate students to publish their ongoing work, an important role in the South African academic context, rather than being the place where outstanding work is normally to be found.

The focus of the joumal on local matters is not so conscious and dominant that one could describe the journal's identity or purpose in those terms, but there are definitely several examples over the last three years of South Africa-focused articles of papers concemed with regional realities and problems.

\section{Essential Technical Features: English Abstracts, Erata, Citation Practice, Presentation}

Consensus Review: In-depth reviews a re published from time to time, but a part from a few book reviews not much else of academic significance is provided as valueadding features. The joumal does, however, honour and celebrate local scholars who retire or passaway.

There are properEnglish abstractsfor all articles. There is no public ation of errata. The citation practice is good, as are the presentation, layout, style and copy-editing.

\section{Usefulness in Capacity Development and Intemational Comparability}

Consensus Review: While the joumal is directed more at esta blished researchers, it is also suitable as a general on-going stimulus and public ation opportunity for local graduate students and young staff. It cannot be considered an intema tional journal, but is comparable with other national journals in its broad field.

\section{Suggested Improvements}

Consensus Review. The journal should be operated and marketed in a way that is more open and inviting to all South African, regional and international scholars, including those who are at the forefront of their areas of focus. Intemational participation in editing and peer review should be enhanced. It ought to have more value-adding features, such as editorials, correspondence and book reviews.

\section{Business Aspects}

The journal's regular print run is 220 copies per issue; it is published by Sunmedia, Bloemfontein. Both production and distribution are outsourced. The joumal does 
not camy either paid or unpaid advertising. Fina ncial sponsorship is received on a regular basis from the University of the Free State and sometimes from other sponsors for special issues, e.g. a special issue on Bible translation received sponsorship from the Bible Society of SA.

The number of paying subsc ribers is only 53, of which 17 are organisations and 36 individuals. The joumal appears free online on the website of the University of the Free State; it is also part of the African Journals Online (AJOL) pay-to-view e-publication service. The journal's total income is about R50 000 per annum, but the total expenditure is at least R60 000. The joumal has never received offers to purc hase from multinational publishers. The current publisher is Sunmedia, but in the years 2006-2008 it was the Publication Office, University of the Free State.

The journal is indexed by Thomson Reuters-ISI, as well as Scopus, but no impact factors are known to the editor. English abstracts are published if articles are not in English. The journal has been reviewed before by both ISI and Scopus.

The editor would in principle be interested in being considered for inclusion in ASSAf's SCiELO-South Africa open access journal platform.

\section{Panel's Consensus View}

I. The joumal should continue to be listed on the DHET list of acc redited journals (over and above its entitlement to this, under policy as an ISI-indexed periodical).

II. The joumal's editor, editorial board and publisher should be careful to retain their intemational indexing status as this can be lost as a result of not meeting the required standards of performance in terms of article numbers, citations, etc. The latter should be closely monitored.

III. The publisher/ editorshould be invited to considerjoining the evolving ScieOSouth Africa platform.

IV. The editor should seriously consider the suggested improvements made in this review, espec ially the emphasis to atract the work of leading scholars, as well as emerging ones, from all over the country and region, as well as intemationally.

V. In addition, the Panel believes that the joumal should offer more valueadding features.

\subsection{2 \\ J OURNALOF THEOLOGY FOR SOUTHERN ARICA}

Foc us and Scope: The J oumal of Theology for Southem Afric a (J TSA) is published from the School of Religion and Theology at the University of KwaZulu-Natal. J TSA has been published continuously since December 1972 as a vehicle to promote theological reflection within the social, political and cultural context of southern Africa. Overthe years, articleshave been published covering a range of issuesand themes such as hemeneutics, public theology, inculturation, liberation theologies, African theology, development, feminism; all of which are directly related to the 'witness of the church' in both Africa and the world. J TSA also published key theological documents to do with the church in South Africa.

Editing Functions: Standing, Local Institutional Spread, Intemational Participation, Peer Review, etc.

Consensus Review: The ed itor and editorial collec tive a re considered to have good national reputations, but are little known internationally. This may be why there are no intemational members on the collective.

Questionnaire: The journal was originally housed in the South African Council of Churches, and then moved to UCT in the 1980s; it moved to UKZN in 2003. It is owned by a Section 21 Company and not by the university or an academic society. It 
has been published for 37 years (since 1972), without significant interruptions. In the three-year period under review, 61 original articles and 35 reviews were published; in the same period, 110 artic le manuscripts were received (an acceptance rate of $55 \%)$; five manuscripts were rejected without peer review. About eight out of 61 artic les, and eight out of 35 reviews had at least one author with a non-South African address. Two or three peer reviewers a re usually approached for each submitted manuscript, and about 56 reviewers were used in 2008, of which only five reviewers had non-South African addresses. All peer-review reports are retained in records.

The average interval between receipt of a manuscript and its public ation in print is three to four months; the journal is not available on the web. The publication frequency of the joumal is three issues per a nnum, and it appears on given dates.

The present editor, who has been running the joumal for six to seven years, was not appointed competitively and the period of a ppointment is open-ended. Members of the editorial board, who are also not appointed competitively, a re drawn from inside and outside the country in order to provide specific topical expertise. Their period of appointment to the editorial board is unspecified. They handle peer reviews of individual manuscripts, and advise on editorial polic ies and practices.

Editorial policy guidelines are published, but there is no policy on conflict of interest. The editorial policy guidelines have been aligned with ASSAf's National Code of Best Practice in Editorial Disc retion and Peer Review. Errata a re published when the need arises. The journal contains editorials and book reviews as value-adding features. The percentage of pages in each issue that represents peer-reviewed original material is close to $100 \%$

\section{Content Quality, Focus, Spread within Domain, Sample of Best Work in SA, Enrichment Features, etc.}

Consensus Review: The articles are generally of high quality and contextual relevance; only just over half of the articles submitted are published. In March 2008, an editorial explained and defended the stric tness of this polic $y$ in a very constructive way.

The number of artic lespublished perannum is a dequate, but is somewhat less that appears in several similar joumals in the country. The articles are seen as a reasonable sample of the best work done in the field of academic theology, especially African theology, in Southern Africa; many of the leading scholars publish here (including a small number of leading intemational voices), and it is noteworthy that many articles are by black authors locally and from other African countries.

There has been a focus on local/regional kinds of materials since the journal's beginnings, and it is still applicable in remaining contextual and representa tive. The a uthors of artic les are dra wn va ria bly from across the country,

\section{Essential Technical Features: English Abstracts, Enata, Citation Practice, Presentation}

Consensus Review: The joumal publishes a limited number of additional schola rly features, including editorials, topical and book reviews, and even news on academic events, from time to time. All artic les have English a bstracts. No errata have been noted. The citation practice is good, as are the presentation, layout, style and copy-editing.

\section{Usefulness in Capacity Development and Intemational Comparability}

Consensus Review: The journal's contextual and regional focus makes it an ongoing source of stimula tion for young students and staff. It is considered by many to be best joumal on African theology in the country. 
Postgraduate students and postdoctoral researchers regularly publish in it. The joumal compares well with the middle tier of intemational joumals, but is not in the same category as the leading intemational joumals.

\section{Suggested improvements}

Consensus Review: The editor and editorial collective should be appointed on a competitive basis. A much wider representation of authors is needed. More international authors and reviewers would also help. The joumal should be available online.

\section{Business Aspects}

The journal's regular print run is 650 copies. It is published by J TSA, a Section 21 Company. The editorial work and distribution are handled in-house, but layout and printing a re outsourced. The joumal ca mies very few paid advertisementsand no unpaid advertising is carried. The journal does not receive financial sponsorship.

The number of subscribers is 417; about half of these are from orga nisations as opposed to individuals. The journal is not available online. The journal's total income in 2008 was about R 156000 and the total expenditure in the same year was about R150 000. The joumal has previously received offers to purc hase from multinational publishers, and several offers to jo in other online publishers. Authors reta in copyright.

The journal is not indexed in Thomson Reuters-ISI, but the editor has applied and is awaiting a favourable response. The joumal is indexed in ATLA, the American Theological Library Association (USA).

English abstracts a re included in all artic les. The editor would in principle be interested in the journal being considered for inclusion in ASSAf's SciELO-South Africa platform.

\section{Panel's Consensus View}

I. The joumal should continue to be listed on the DHET list of acc redited joumals.

II. The publisher/ editorshould be invited to considerjoining the evolving ScielOSouth Africa platform.

III. The editor should seriously consider the recommendations listed in this consensus review.

\subsubsection{VERBUM ETECCLESIA}

Foc us and Scope: Verbum et Ecclesia is the academic joumal of the Dutch Reformed Church at the Faculty of Theology, University of Pretoria.

\section{Editing Functions: Standing, Local Institutional Spread, Intemational Participation, Peer Review, etc.}

Consensus Review: The editor-in-chief, associate editor and the members of the editorial board have national reputations; the international advisory board (since 2009 divided according to regions of the world: Afro-Asian section; American section; European section) includes several scholars with sound international reputations. It would be a good idea to bring some of the latter into the former structure (also using them in peer-review processes) to play a more direct role in building the journal's wider reputation.

Questionnaire: The journal has been published for 30 years without significant intemuptions. In the three-year period from 2007-2009, the number of published 
original articles was 132, and seven book reviews; in the same period, 152 article manuscripts were received, giving a problematically high acceptance rate of $87 \%$. No manuscript was rejected without peer review.

From 2007-J un 2009 about a quarter of published artic les had at least one author with a non-South African address. Usually two to three peer reviewers are approached per submitted manuscript. In 2008, 97 reviewers were used, of whom just under $10 \%$ had non-South African addresses. All peer-review reports are retained in records.

The average interval between receipt of a manuscript and its public ation in print is approximately between $12-15$ months, while on the web it is about two months. The public ation frequency of the joumal from 2010 is one a nnual issue, but prior to 2009, two issues were published every year. The joumal issues appear at infrequent intervals.

The present editor, who has been editing the joumal since 2002, was appointed competitively following nomination and selection processes. The editor's appointment was for a period of five years, and he was reappointed in 2007. Members of the editorial board are not appointed competitively, but are selected and approached based on expertise and profile. Their appointment period is three years. They handle peer reviews of individual ma nuscripts, and advise on editoria I polic ies and practices. The editorial board consists of members from inside and outside of South Africa, who are appointed to provide specific topical expertise.

Editorial policy guidelines are published, and the journal has a conflict of interest policy. The editorial policy guidelines have been aligned with ASSAf's National Code of Best Practice in Editorial Discretion and Peer Review. Errata are published when needed. The journal publishes editorials, topical reviews, book reviews and occasionally correspondence on published articles as value-adding features. The percentage of pages in each issue that represents peer-reviewed original material is nevertheless claimed to be $99 \%$.

\section{Content Quality, Focus, Spread within Domain, Sample of Best Work in SA, Enrichment Features, etc.}

Consensus Review: The academic quality of the artic les is genera lly a dequate to good. The number of artic les published in a year is also satisfactory when compared with similar joumals. The high acceptance rate is disturbing, however, and much higher than that of comparable joumals.

The journal presents some of the best work done in the country, since some of the leading scholars in a variety of theological disciplines (some associated with the home institution of the joumal) publish regularly in it. Not all the papers represent leading scholarship.

Although there are exceptions and although it is difficult to generalise, the topics do not reflect a clear focus (for example on local or regional problems). The papers rather seem to address general issues in the different fields and disciplines that could just as well have been written and published elsewhere in specialist joumals. The very large number of scholars represented on the advisory editorial board from many places on the globe underlines this aspirant characteristic of the joumal, which is not reflected in a commensurate number of papers from international authors (only $10 \%$ of the total). The $90 \%$ of authors who a re local a re probably not representative of institutions a cross the country, either, with a strong bias towards the home institution.

The joumal does offer opportunity for research assistants and postgraduate students to publish their work. 
Consensus Review: There are more book reviews in the journal than in most comparable joumals, but no topic al reviews and substantial editoria Is. All a ric les have proper English abstracts. Public ation of errata is not visible, perhaps not so necessary. The citation practice is satiffactory, as a re the presentation, la yout, style and copy-editing.

\section{Usefulness in Capacity Development and Intemational Comparability}

Consensus Review: The joumal is suita ble as a general on-going stimulus for local graduate students/young staff in the discipline, as well as for intemational students, particula rly students from other Afric an countries. The languagesaccepted for submissions are English, Afrikaans, German, Dutch and Sepedi.

The joumal can serve as a platform for critical research on the connections that exists between religion and so ciety, with applic a tions in the humanities, social sciences, and natural sciences. This broad focus expands the borders of foc used theological research by combining theological disciplines with other scientific disciplines in contemporary tems.

The joumal compares rea sonably well with a number of intemational joumals, but it is not in the same category as the leading intemational joumals.

\section{Suggested Improvements}

Consensus Review: Attempts should be made to attract more intemational members to the editorial board, as well as peer reviewers and especially contributing authors. At the same time, the reach of the joumal in a wider spread of local institutions should be increased, and a more open partic ipation model followed.

The rigour of independent peer review should be tightened, and strong editorial disc retion a pplied.

Measures should be adopted to ensure the proper independent peer review of artic les by the editors.

Articles should be published more quickly in the print edition.

The journal should keep to a fixed schedule of print publication.

\section{Business Aspects}

The idea of a regular print run does not apply as the journal is a 'roll on' e-publication, papers being published free online as soon as they are accepted, and printed in a single annual version later. The publisher is Open J oumals Publishing, a division of AOSIS (Pty) Ltd, on a commercial basis; production is outsourced. The journal does not carry either paid or unpaid advertising, but it receives financial sponsorship.

There are no paying subscribers as this is a free online, open access joumal, accessible at www.ve.org.za. The journal's total income per year is not known; the total expenditure was R120 000 in 2009. The joumal has never received offers to purchase from multinational publishers. Copyright resides with authors.

The journal has applied to be indexed by Thomson Reuters-ISI. English abstracts and front deta ils a re published for all articles. The joumal was previously independently peer-reviewed. The journal's publisher is already working with ASSAf and SCIELO-SA for the journal possible inclusion on the platform. 


\section{Panel's Consensus View \\ I. The joumal should continue to be listed on the DHET list of acc redited joumals. \\ II. The publisher/ editorshould be invited to considerjoining the evolving ScieO- South Africa platform. \\ III. The editor should seriously consider the findings and recommendations listed in this consensus review, partic ularly those that apply to greater in- temational and wider national partic ipation at all levels in the joumal, and tighter peer review.}

\section{SCRIPIURA}

Foc us and Scope: Sc riptura is an independent joumal which publishesc ontributions in the fields of Bible, religion and theology. It is international in scope but special attention is given to topics and issues emerging from or relevant to Southern Africa. Scriptura publishes contributions in English, but a lso in other languages releva nt to the Southern African region (such as Afrikaans, Xhosa, Sesotho, Zulu, French and German).

\section{Editing Functions: Standing, Local Institutional Spread, Intemational Partic ipation, Peer Review, etc.}

Consensus Review: The three active co-editors have good national (and perhaps even international) reputations; most (although not all) of the members of the editorial board are South Africans, and all are senior and respected scholars in their respective fields, some of them with scholarly reputations that extend beyond this country's borders; the international advisory board consists of well-known and highly respected scholars.

Questionnaire: The journal has been published for 30 years without significant intemuptions. During the three-year period under review, the number of published original articles was 121 and that of book reviews, ten; in the same period, 153 article and 12 book-review ma nusc ripts were received, giving an a ric le acceptance rate of around $80 \%$. No manuscript was rejected without peer review. Two book review artic leswere rejected by the editorbecause they were not up to standard.

About a quarter of the published articles (and a fifth of two of the book reviews?) had at least one author with a non-South African address. At least two peer reviewers are usually approached per submitted manuscript; a third reviewer is used when there is a marked difference of opinion between the first two reviewers. In the years 2007, 2008 and 2009, respectively, no fewer than 85, 65 and 96 reviewers were used. Of these peer reviewers, over a quarter had non-South African addresses. All peer-review reports are retained in the records.

The average interval between receipt of a manuscript and its publication in print is approximately 11 months. The public ation frequency of the joumal is three volumes per year, but the issues are not pre-scheduled to appear on given dates.

The present editor, who has been running the joumal for ten years, was not appointed competitively (i.e. following advertisement and a selection process). Members of the editorial board are also not appointed competitively; their period of appointment is not specified. They handle peer reviews of individual manuscripts, and advise on editorial policies and practic es. The editorial board consists of members from inside and outside of South Africa.

Editorial policy guidelines are published, and the journal has a conflict of interest policy. The editorial policy guidelines have been approximately aligned with ASSAf's National Code of Best Practice in Editorial Discretion and Peer Review. When it is necessary, errata are published. The joumal publishes editorials infrequently, but has topical reviews and book reviews as value-adding features. The percentage of 
pages in each issue that represents peer-reviewed original material is $96 \%$, as only the book reviews are not peer-reviewed.

\section{Content Quality, Foc us, Spread within Domain, Sample of BestWork in SA, Enrichment Features, etc.}

Consensus Review: The qua lity of the artic les accepted and published is generally good, although they tend to be shorter than is found in other similar journals; there is a strict review process in place. While the average artic le published represents solid and useful, contextually appropriate work in the different sub-fields that are covered, a moderate proportion are written by some of the best-known and most respected scholars in these fields in the country, drawn from many institutions, as well as by a reasonable number of intemational contributors. On balance, however, the journal does not attract the best work in the country in the field of theology. There is a sufficient focus on local and regional kinds of problems. Postgraduate students a re also sometimes given the opportunity to publish their own research and on-going work.

\section{Essential Technical Features: English Abstracts, Enata, Citation Practice, Presentation}

Consensus Review: Almost every issue also includes a topical review, but the emphasis is clearly on peer-reviewed articles. All published artic les have English abstracts. No errata were noted. The c itation practice is good, asare the presentation, la yout, style and copy-editing.

\section{Usefulness in Capacity Development and Intemational Comparability}

Consensus Review: The joumal is suitable as a general, on-going stimulus for local graduate students and young staff in the disciplines concemed. The contextual nature of the joumal provides young theologians with useful insights. The joumal is accessible and the artic les readable for young students and theologians, and the joumal is affordable.

The joumal is generally not comparable with the leading intemational joumals in this area.

\section{Suggested Improvements}

Consensus Review: The conciseness of the articles impacts on their quality; lengthier discussions would provide more depth to the joumal. The joumal needs to stay on schedule with its intended publication dates. Efforts should be made to attract more intemational editors, contributors and peer reviewers. Thought needs to be given as to whether the publication of papers presented at conferences is necessarily good for the qua lity of the joumal. There also needs to be a selection process of the editor.

The joumal could improve its impact by being more available (free online) on the web.

\section{Business Aspects}

The journal's regular print run is 180 copies; it is published by Readme Services. Production is done by a part-time editorial assistant, while the distribution is done with Postnet by the departmental administrative officer. The journal does not carry either paid or unpaid advertising. The editorial assistant responsible for the la yout and communic ation with the printer is paid by the university (R29 000 peryear).

The number of paying subscribers is 160 , of whom a bout $75 \%$ a re libra ries. The joumal is part of the SABINET commercial (pay-to-read or subscribe) e-publication service. 
The journal's total income per year is R70 000 (R50 000 as page fees and R20 000 as subscriptions), plus the salary of the editorial assistant, and total expenditure is R95 000 per annum. The joumal has previously received two offers to purc hase from multinational publishers. Copyright is allowed to authors if the item concerned is published as part of an author's collected works that focus on a specific topic or in translated form. The 'second' publication must clearly reflect that the article was initially published in Sc riptura.

English abstracts and front details a re published for all articles. The joumal was independently peer-reviewed in 2005. The editor would in principle be interested in the journal being considered for inclusion in ASSAf's SciELO-South Africa open access platform.

\section{Panel's Consensus View \\ I. The joumal should continue to be listed on the DHET list of acc redited joumals. \\ II. The publisher/editor should be invited to join the evolving SciElO-South Africa platform. \\ III. The editor should seriously consider the findings and recommendations made in this consensus review.}

\subsection{Specific Theological Traditions}

\subsubsection{IN DIE SKRIRUG (NEW TITE: IN LUCE VERBI)}

Focus and Scope: In die Skriflig is a theological journal which seeks to reflect the practice and growth of reformational theology in a scholarly manner "in service of the Church and the Kingdom of God".

Editing Functions: Standing, Local Institutional Spread, Intemational Participation, Peer Review, etc.

Consensus Review: The joumal is a well-established joumal with a reasonable national but limited intemational reputation. The editor is considered to have intemational standing in his disc ip line, as is shown by his NRF rating, and the same generally goes for the national editorial associates. While the members of the editorial board seem all to be from one, perhaps two, South African universities (University of NorthWest (Potchefstroom campus) and the University of the Free State), the journal has reputable intemational associates.

Questionnaire: The joumal has been published for 42 years without intemuption. Between 2006-2008, about 90 original peer-reviewed articles and six book reviews were published; about 112 article manuscripts were received in the same period (about $80 \%$ acceptance rate). Very few manuscripts were rejected without peer review. Less than $10 \%$ of the published papers had at least one author with a nonSouth African address. Three peer reviewers are usually approached for each submitted manuscript. In 2008, 90 peer reviewers were used, of whom approximately $20 \%$ had non-South African addresses. Peer-review reports are accessibly retained in the records. The average interval between receipt of a ma nusc ript and its publication in print and on the web is anywhere between three and nine months. The publication frequency of the joumal is four issues per year. The issues a ppear regula rly on the scheduled dates.

The present editor has been running the joumal for three years, and was appointed for a period of four years with the option to continue after that. The editor's appointment was not based on competition/selection. Members of the editorial board are appointed from inside and outside the country, in order to provide specific topical expertise. Occasionally, members of the editorial board handle 
the peer reviews of individual manusc ripts, and they advise on editorial policies/ practices.

Editorial policy guidelines are published, and a conflict of interest policy has also been developed. The editorial policy guidelines have been aligned with ASSAf's National Code of Best Practice in Editorial Disc retion and Peer Review. It was not necessary so farto publish errata, but if needed, this will be done.

The joumal publishes value-a dd ing features such a seditoria ls, news and views, topical reviews, book reviews and correspondence on published articles. The percenta ge of pages in each issue that represents peer-reviewed orig inal material is about $75-80 \%$.

\section{Content Quality, Foc us, Spread within Domain, Sample of Best Work in SA, Enrichment Features, etc.}

Consensus Review: The quality of the published artic les is generally good, with some being high. A fa ir number of artic les (30) are published perannum. They a re a good sample of the best work done in the country in the broad field of theology, revealing sound scholarship on the whole but predominantly within the Gereformeerde family of scholars. There is a limited focus on local/regional kinds of materials or topics. There is a concentration of a uthors from North-West University, and although the editor states that $7 \%$ of the authors are intemational, the a uthors concemed seem to be mostly from the Netherlands.

\section{Essential Technical Features: English Abstracts, Enata, Citation Practice, Presentation}

Consensus Review: The journal carries features such as editorials, book reviews and a feature called 'Fokus' for emerging theologians. All articles have proper English and Afrikaans abstracts. Publication of errata may be practiced but no example was observed. The joumal has a sound citation practice. The hard copies are well presented.

\section{Usefulness in Capacity Development and Intemational Comparability}

Consensus Review: The joumal is suitable as a general on-going stimulus for local graduate students and young staff, but this is mostly limited to its confessional pool. The journal is not comparable with leading international journals in the field, but it is good within its confessional framework.

\section{Suggested Improvements}

Consensus Review: A broader range of authors from within South Africa and more intemational sc holars, especially from other Afric an countries, need to be involved as both a uthors and editorial board members, even if only within the Gereformeerde family. In order to reach a wider constituency, however, the joumal also needs to broaden its base outside the Gereformeerde circle.

One suggestion has been that the institutional affiliations of the authors should be provided in the table of contents.

The editor should preferably be selected competitively, as should members of the editorial board.

\section{Business Aspects}

The journal's regular print run is about 235 copies, and it was published by $V \& R$ Printing Works, Pretoria and recently open accessible by AOSIS Publishers. Both 
production and distribution a re outsourced. The journal does not camy paid advertising but sometimes includes unpaid a dvertising. The joumal receives an unspecified level of financial sponsorship.

The jo umal has 164 paying subsc ribers, of which number 62 are orga nisations as opposed to ind ividuals. The joumal is part of a commercial pay-to-view and/orpay-tosubsc ribe e-public a tion service. Its a nnual total income is just over R62 000, while total expend iture is about R70 000. The joumal has never received offers to purc hase from multinational publishers.

The submission of an artic le entitles In die Skriflig to exclusive rights of publication, both in printed and in electronic and other media. No ISI-type impact factor has to date been determined for the journal. Front details like titles, authors, addresses, and English abstracts are included in the joumal. The editor would in principle be interested in the journal being considered for inclusion in ASSAf's SciELO-South Africa open access journal platform.

\section{Panel's Consensus View}

I. The joumal should continue to be listed on the DHET list of acc redited joumals. II. The publisher/ editorshould be invited to considerjoining the evolving ScielOSouth Africa platform.

III. The editor should seriously consider the recommendations listed above, especially those pertaining to broadening the confessional and regional geographic base of the joumal, with respect to both authors and editorial board members.

\subsection{2}

\section{NEDERDUITS-G EREFORMEERDE TEOLOGIESE TYDSKRIF (NGTI)}

Focus and Scope: The NGTT or Nederduits-Gereformeerde Teologiese Tydskrif is an open-access peer-reviewed academic journal with a focus on Christian theology. As the name suggests, the journal ha shistorical ties with the Reformed tradition, yet this is coupled with the strong ecumenical commitment of the University of Stellenbosch. The journal is serious about promoting multilingualism, and features theological research that stretches a cross all the theological subdisciplines and even interdisciplinary engagement with other academic fields.

Editing Functions: Standing, Local Institutional Spread, Intemational Participation, Peer Review, etc.

Consensus Review: The journal is a very old and established journa I with a sound national and a reasonable intemational reputation. Both recent editors certa inly had national, perhaps a measure of intemational standing, in the discipline, while the members of the editorial board mostly have national standing. The journal also has international associates with good reputations in the field.

Questionnaire: The history of the NGTT, a lthough not under its current name, dates back to the years 1849 and also the years after the founding of the Stellenbosch Theological Seminary (1859) when its future and later teachers used journals like the De Kerkbode and its predecessor De Gereformeerde Kerkbode (from 1849), Het Nederduitsch Zuid-Afrika anse Tijdschrift (from 1877), Het Gereformeerde Maandblad (from 1892) and also Het Zoeklicht (from 1923); Die Ou Paaie (from 1926) and De Gereformeerde Vaandel (from 1934) for the publication of their articles. Since the founding of the NG TT in 1959 as a continuation of the above-mentioned long tradition of Reformed publications, the readers of the NGTT have been academic theologians, scholars in the field of humanities and social sciences, professional pastors/ministers of religion and aca demic ally onented readers interested in theological, ec clesiastical and religious matters. There has been no intemuption in public ation since 1959. 
For the period of 2006-2008, the number of published original articles was 158 out of 169 article manuscripts received, a perhaps disturbing acceptance rate of over $93 \%$. No manusc nipt was rejected without peer review. About 108 published papers had at least one author with a non-South African address. Two peer reviewers are usually approached for each submitted manuscript. In 2008, 106 peer reviewers were used, of whom only $5 \%$ of had non-South African addresses, a very low percentage, suggesting minimal intemational partic ipation in quality assurance. Peer-review reports are all retained in the records.

The average interval between receipt of a manuscript and its public ation in print is approximately six months. The publication frequency of the joumal is two issues peryear, pre-scheduled to a ppear in J une and beginning December.

The previous editor ran the joumal from 2000 until 2010, since when a new editor took over, also from the University of Stellenbosch, who unfortunately passed away early 2013. The editor is appointed competitively, in being selected from a number of persons who have been nominated. Members of the editorial board are nominated by the three Faculties of Theology at the Universities of Stellenbosch, Bloemfontein and Pretoria; this board then appoints a broader board of co-workers. The board members handle peer reviews of individual manuscripts, and advise on editorial policies and practices. The editorial board consists of members drawn only from inside the country, while the co-workers are appointed on the broader editorial board for their topic al expertise.

Editorial policy guidelines have been published, and a conflict of interest policy is implic itly included in the polic y of the joumal. The editorial polic y guidelines have as far as possible been aligned with ASSAf's National Code of Best Practice in Editorial Discretion and Peer Review. When it is necessary, errata a re published. The journal contains editorials, topical reviews, and book reviews as value-adding features. The percentage of pages in each issue that represents peer-reviewed original material va ries.

\section{Content Quality, Foc us, Spread within Domain, Sample of Best Work in SA, Enrichment Features, etc.}

Consensus Review: The published artic les, which a re of good to high qua lity, number over 50 articles per annum, amongst the highest in the country's local journals. What is published is therefore a good sample of the best work done in the country in the field of theology. There is a balanced focus on universal issues and those which are local/regional (except in the 2010 supplement, which was much more focused solely on local/regional matters); amongst the topics are church unity, the relationship between church and state, public theology, reconciliation in South Africa, and human rights in South Africa.

While articles in the NGTT certainly reflect the strong heritage of Reformed theology in South-Africa, many articles address issues that transcend denominational and institutional boundaries, as a lready stated above.

There is a predominance of artic les published by authors from the Universities of Stellenbosch, Pretoria and the Free State, although a number are contributed by authors at other SA universities, and from abroad - the latter mainly from persons who have an adjunct capacity at one of the named universities.

\section{Essential Technical Features: English Abstracts, Enata, Citation Practice, Presentation}

Consensus Review: The only value-adding features are a few editorials, which have the character of sharing local and denominational newsorpersonalia, infrequent topical reviews, a small number of book reviews, but no correspondence. 
The editorials have the character of sharing local and denominational news, which gives them a 'personalia character'. The book reviews are relatively few. All artic les have proper English abstracts.

Publication of errata was not noted. The citation practice is sound, but the referencing systems vary between papers, and the use of footnotes varies from none to overwhelming. The presentation, layout, style and copy-editing a re well done (Note the recommendation 3 below).

\section{Usefulness in Capacity Development and Intemational Comparability}

Consensus Review: A reasonable number of local graduates and younger researchers publish articles in the joumal, which is suitable as a general on-going stimulus for local graduate students and young staff in the disc ipline.

The joumal compares well with a number of other local joumals, but is not in the class of the best intemational theological joumals.

\section{Suggested Improvements}

Consensus Review: The editor and editorial board should seek more participation from intemational peer reviewers and especially from other African countries, as well as broadening the scholarly network within the country itself.

It would help in this respect if the page with information on the editorial board and the co-workers were printed in English, as well as in Afrikaans.

There should also be more depth to the editorials, for example by giving a summary and even an appraisal of the articles in the issue concemed, rather than sharing local and denominational news, which is a practice that is not only dated, but creates the impression that the journal is intended for a very definite (local) denominational readership.

At present the page layout is rathercrowded since the start of a new paragraph is marked only by an indented first line; if the spacing between paragraphs could be doubled, it would make for much easier reading.

A consistent referencing style should be enforced, and the same for the use by a uthors of footnotes.

\section{Business Aspects}

The journal's regular print run is 300-350 copies. Since 2011, an e-version of the joumal has been published free online, and a recent development is a project in which the full arc hive of past issues will be digitised. Both production and distribution a re outsourced.

The journal carries very little paid advertising, but does receive financial sponsorship. The number of paying subscribers is a bout 300 , of whom all but 25 are individuals.

The journal's total income from 2008-2009 was R77 000, and the total expenditure in the same period was R84 000. The journal has never received offers to purchase from multinational publishers. The joumal owns the copyright of the artic les published.

English abstracts are published for all articles. The joumal has never been independently peer-reviewed before. The editor in principle would be interested in 
the journal being considered for inclusion in ASSAf's SciELO-South Africa platform, if this leaves it financially viable.

\section{Panel's Consensus View}

I. The joumal should continue to be listed on the DHET list of ac c redited joumals.

II. The publisher/ editorshould be invited to considerjoining the evolving ScielOSouth Africa platform.

III. The editor should seriously consider the suggestions for improvement listed above.

IV. In addition, the Panel believes that the joumal needs to exert a greater international influence in the broad discipline of theology, with implications for editorial policy, rigorous peer review, and widening of the constituency.

\subsection{3}

\section{SOUTH AFRICAN BAPIISTJ OURNAL OF THEOLOGY}

Foc us and Scope: The So uth Afric an Baptist J oumal of Theology (SABJ T), published annually in September, is South Africa's only evangelical peer-reviewed and DHETaccredited theological joumal, specia lising in many aspects of theology and ministry. The journal's inaugural issue appeared in 1992 with the intention to further evangelic al scholarship, and through it to serve the ministers and members of the Baptist Union of South Africa (BUSA), as well as the broader evangelical churches in Africa and the rest of the world. The joumal has a dual purpose, serving academia (peerreviewed a ricles) and the church (ministry and laity). SABJ Tis housed at Cape Town Baptist Seminary.

Editing Functions: Standing, Local Institutional Spread, Intemational Participation, Peer Review, etc.

Consensus Review: Information is sparse, but the editors appear to be involved in education and hold doctorates; two members of the editorial board are from Australia, one from Ireland, while three are from universities in South Africa. The editors do not appear to have substantial national or intemational disciplinary reputations.

Questionnaire: The journal has been published for 18 years without significant intemuptions. The number of published original artic les duning the three-year period under review was 77 articles and 21 book reviews; in the same period, 78 article manusc ripts were received, of which one was rejected without peer review and all the others were accepted, a disturbing ly high acceptance rate of nea rly $100 \%$. About a quarter of the published papers and two reviews had at least one author with a non-South African address.

Usually two peer reviewers a re approached for each submitted aca demic manuscript; only 11 peer reviewers were used in 2009, all of them South Africans. Book reviews a re not peer-reviewed, and accredita tion is not sought by a uthors/ institutions. Peer-review reports are accessibly retained in records. The average interval between receipt of a manuscript and its publication in print is five months. The journal is not published on the web at present.

The joumal is published once peryear. The joumal issuesare sc heduled to appear in the last week of each September, and this deadline has always been met to date.

The present editor has been editing the journal since September 2008; the term of office expires in September 2011 . The editor was not appointed competitively. Editorial board members a re also not a ppointed competitively, and theirappointment period is not specified. They are appointed from inside and outside the country in order to provide specific topical expertise. Members of the editorial board handle peer reviews of individual ma nuscripts, and advise on editorial polic ies/practices. 
Editorial policy guidelines are published but the journal has no conflict of interest policy. The editorial policy guidelines have been aligned with ASSAf's National Code of Best Practice in Editorial Disc retion and Peer Review. Errata are published when nec essary.

The journal contains only book reviews as value-adding scholarly features. The rest of the pages in each issue (more than $90 \%$ ) represent peer-reviewed orig inal material.

\section{Content Quality, Focus, Spread within Domain, Sample of Best Work in SA, Enrichment Features, etc.}

Consensus Review: The artic les seem generally to be of average to good quality. The bibliographies of the papers are sufficient and show interaction with published research. A reasonably large number of peer-reviewed articles are published per year, averaging 26. The contextual links to the Baptist Church and the challenges of evangelism are handled sensitively, while there is a foc us on cha llenges to evangelism in South Africa in the post-modern context, and on cultural diversity of groups. There is a fair representation of authors from various parts of South Africa, some from Australia, New Zealand, and Malawi. One South African has four articles in the 2010 issue. The a uthors a re from the circle of Baptist and other conservative evangelic al scholars ( $50 \%$ of subsc ribers are not Baptists).

There are very few Baptist joumals with which to compare this one. The high rate of acceptance of submitted manuscripts is very womying, as is the absence of intemational reviewers.

\section{Essential Technical Features: English Abstracts, Enata, Citation Practice, Presentation, etc.}

Consensus Review: The joumal conta ins some good editorials, but no topical reviews, while the eight book reviews are not confined to scholarly works. Abstracts were not published for artic les until 2011, since when they have been made compulsory. No public ation of errata was noted. The citation practice is satisfactory, as are the presentation, layout, style and copy-editing (although the title of one article contained an emor).

\section{Usefulness in Capacity Development and Intemational Comparability}

Consensus Review: The joumal is intended to be used as a development tool for Honours, Masters and doctoral students to enable them to gain experience in writing for publication; for this reason it publishes articles submitted by such students. Despite this policy, the journal's suitability as a general on-going stimulus may well be limited to local graduate students and young staff within Baptist and conservative evangelical circles. It is difficult to judge the journal's comparability with other similar journals in the field, but it is not amongst the leading journals within that tradition.

\section{Suggested Improvements}

Consensus Review: All artic les should have proper abstracts, and the peer-review process should be more thorough and rigorous through drawing reviewers from a much wider range of institutions and geographical bases, some of them intemational, followed by careful consideration by the editor of the review reports concemed.

At present the joumal is published once a year. The non-schola rly articles dealing with themes related to pastoral ministry and church mission should at the very least 
be presented in a clearly separated section of the joumal. The scholarly section should strive to do more than primarily serving the specific purposes of the Baptist Union of South Africa, its ministers and mission. The problematic dual role of the journal impacts on the standing of a journal which seeks recognition as being genuinely scholarly. This issue must be considered at a fundamental level of policy.

\section{Business Aspects}

The regular print run of the journal is 700 copies per issue; it is published by the Baptist Union of Southern Africa. Production is outsourced and distribution is partially outsourced. The joumal does not ca my neither pa id nor unpa id a dvertising. It a lso does not receive any financial sponsorship.

The number of paying subscribers is 225; of these, 42 a re orga nisations as opposed to individuals. The journal does not appear online yet. The journal's total income in 2009 was about R126 000, while the total expenditure was R63 755.

The joumal has never received offers to purchase from multinational publishers. Published articles are the property of the journal; the editor states that if the article has a lready been published elsewhere and is re-published in this joumal, copyright belongs to the joumal in which it was originally published - re-publication is a very bad practice.

All published articlesare in English. The joumal has never been independently peerreviewed before. The editorand the publisherare open to inclusion of the joumal in the ASSAf SCiELO-South Africa online platform.

\section{Panel's Consensus View}

I. The joumal should not continue to be listed on the DHET list of accredited joumals.

II. The publisher/ editor should not be invited to consider joining the evolving Sc iElO-South Africa platform, until the shortc omings described in this consensus review have been demonstrably overcome.

III. The editor should seriously consider the findings and recommendations listed above, and particularly foc us on the issue of rigorous, independent and multiple peer review of articles submitted from a wider field of scholarly activity (an acceptance rate of near $100 \%$ is not creditable).

IV. In addition, the Panel believes that the joumal needs to consider whether its dual purpose could not be better served by separating the content into two publications.

\subsubsection{HIS TEOLOGIESE STUDIES - THEOLOGICALSTUDIES (Incorporating: Practical Theology)}

Foc us and Scope: HTS ha spublished original research concemed with the dissemination of the results of theologic al research of national and intemational scholars since 1943. The joumal has a wide multi-disciplinary scope and supports theologians, philosophers, scholars, ministers of religion and specialists in religious and socially related subjects by providing them with evidence-based, peer-reviewed outcomes of research. The joumal covers theology in its broadest sense and therefore publishes articles linked with a variety of other study fields, and has a multidisciplinary, multi-church, inter-faith, and multi-religious foc us and scope. Articles cover, among others, aspects of religious studies, philosophy, ancient Semitic and classical languages, sociology and ethics. HTS Teologiese Studies/Theological Studies is committed to the capacity building of young scholars.

Practical Theology is foc used on communic ation acts that serve the gospel of the 'Kingdom'. These are not only communication acts of the congregation but also 
actions of the faithful outside the formal context of the congregation. In fact, the field of study touches on the actions on the congregation in worship, the congregation in training and the congregation in its functioning.

\section{Editing Func tions: Standing, Local Institutional Spread, Intemational Participation, Peer Review, etc.}

Consensus Review: This joumal, which is well-esta blished nationa lly and intemationally, despite its editorial 'home' (title-holder) in the Hervormde Teologiese Kollege in the Faculty of Theology at the University of Pretoria. It is the old est theologic a l joumal in the country and a modem macro joumal that servesa very wide scope of a uthors and theological and related academic disciplines. Consultations between the editors, the joumals Practical Theology in South Africa and HTSTeologiese Stud ies/Theologic al Studies which began in 2007, led in 2009 to a decision to continue asa single theological research joumal, namely, HTS Teologiese Studies/Theological Studies. Since 2010, Practical Theology in South Africa has ceased to be an independent scholarly joumal and has been fully incomorated within HTS Teologiese Studies/ Theological Studies (ISSN: 0259-9422) as a permanent single issue per annum, with practical theology as its theme. The tradition of publishing original, scholarly and peer-reviewed research within practical theology as a theological sub-discipline is thus continued.

The editor of HTS has been highly regarded intemationally for many years, as has the joumal itself. The associate editor is considered to be in roughly the same league. The editorial board is representative not only of the theological sub-disciplines within its focus, but extends outside South Africa with some of its members in this category a lso having considerable intemational standing.

Questionnaire: The joumal has been published for 70 years without intemuption. In the three-year period under review, 254 original articles and 158 reviews were published; as 328 article manuscripts were received, the acceptance rate for them was about $77 \%$. No manusc ript was rejected without peer review. Approximately $15 \%$ of the published papers had at least one author with a non-South African address. Two peer reviewers were approached for each submitted manuscript (excepting in cases where papers were authored by the editor, when three reviewers were approached); about 130 reviewers were used in this time, 34 of them with non-South Afric an addresses. In all cases, peer-review reports a re retained in the records.

The average interval between receipt of a manuscript and its publication in print was 15 months; for the web version this was about 50 days.

Between 1985 and 2008, four issues appeared on time every year. At the beginning of 2009, commencing with Volume 65 of HTS Teologiese Studies/Theologic al Studies, the Netherdutch Reformed Church of Africa entered into a publishing agreement with African Online Scientific Information Systems (Pty) Ltd (AOSIS), which provides various servic es, including but not limited to the provision of scholarly public ation services through its scholarly publishing division known as Openj oumals Publishing. Since then, the journal has been published fully online, playing a pioneering role in the digitising of theological journals in South Africa. It has been indexed in Thomson-Reuters-ISI (since 2007), Elsevier Scopus (since 2008) and SciELO-SA (since 2010).

The present editor has been in charge of the journal for 26 years. He was appointed competitively by nomination and selection every year since then, at official meetings of the editorial board. The actual period forappointment is thusone year, but is renewable.

Members of the editorial board occasionally handle the peer reviews of individual manuscripts. They also advise on editorial policies and practices. They are ap- 
pointed, presumably also by the editorial board, based on theirexpertise and profile, and for unspecified periods. They are appointed from both inside and outside the country in order to provide specific topical expertise.

Editorial policy guidelines are published, and the journal has a conflict of interest policy. The editorial policy guidelines have been aligned with ASSAf's National Code of Best Practice in Ed itorial Disc retion and Peer Review. Errata a re published when the need arises. The journal contains editorials, topical reviews, book reviews and occasionally correspondence on published articles, as value-adding features. The percentage of pages in each issue that represents peer-reviewed original material, as stated by the editor, is nevertheless very high (99\%).

\section{Content Quality, Foc us, Spread within Domain, Sample of Best Work in SA, Enrichment Features, etc.}

Consensus Review: The papers which are published are generally of a high qua lity, and the total number published in the review period was close to a hundred, a remarkable achievement for a locally published journal. It is certainly a good sample of the work done in the country in theology. Publication of articles is by authors from across the country, and internationally. Very few black African authors have published in HIS up to the present time (about 13\% of authorships in 2012). The articles and reviews exhibit a balanced focus on local/regional issues, as well as more universal issues. The policy of the joumal is not to request a uthors to reveal their denominational attachments; the editor has nevertheless estimated that not more than $20 \%$ of authors from 2008 to 2012 were members of the Hervormde Kerk, and not more than $5 \%$ of articles addressed issues concerning this specific denomination. More than $25 \%$ of authors were from local institutions not having any affiliation with the so-called sister churc hes or the Hervormde Kerk itself, and about a third of all authors in this period were from outside South Africa.

\section{Essential Technical Features: English Abstracts, Erata, Citation Practice, Presentation}

Consensus Review: The journal carries features such as book reviews but no editorials, topical reviews or correspondence. All artic les have proper English abstracts. Publication of errata is not evident. The joumal has a sound citation practice. The hard copies are very well presented, with excellent layout and style reflecting much attention to detail.

\section{Usefulness in Capacity Development and Intemational Comparability}

Consensus Review: The joumal is very suitable as a general on-going stimulus for local graduate students/young staff in the theological disciplines. A reasonable number of local graduates and younger researches published in the joumal. Its comparability with leading international journals in the field is very apparent.

\section{Suggested Improvements}

Consensus Review: The joumal could be improved by (i) including editorials, correspondence and debates that might help attract potential new readers; (ii) locating the issues within the broadest possible context, attracting authors who might engage the issues differently and stimulate a wider discussion; and (iii) by including articles that relate more to the Afric an continent generally (e.g. more authors from other parts of Afric a).

\section{Business Aspects}

The journal's regular print run is about 1000 copies, and it is published by OpenJournals Publishing, a division of AOSIS (Pty) Ltd, a commercial publisher. Produc- 
tion is outsourced, and distribution does not apply as the joumal is openly accessible online. The joumal does not camy either paid or unpaid a dvertising. Fina ncial sponsorship is received, but the extent was not revealed.

The number of subscribers was about 600 for 2009; these were not paying subscribers because HTS is a free-online, open access joumal accessible at www.hts.org . za. The journal's total expenditure has not been revealed. The journal has never rec eived offers to purc hase from multinational publishers, but several offers to jo in other online publishers; the journal is already on the SciELO-SA platform with the help of its publisher, OpenJ ouma Is Publishing.

Copyright resides with authors.

English abstracts are published if articles a re not in English. The joumal has been independently reviewed before.

\section{Panel's Consensus View}

I. The joumal should continue to be listed on the DHET list of accredited joumals (overand above itsentitlementto this, under policy asan ISI-indexed periodical).

II. The joumal is well worthy of its place in the ScieLO-SA collection.

III. The editor should seriously consider the recommendations listed above.

\subsection{Science/Scholarship in Theology}

\subsubsection{KOERS: BUUEIIN FOR CHRISTIAN SCHOLARSHIP}

Foc us and Scope: Koers is an interdisciplinary journal. Articles from all fields of academic research in Christian scholarship are therefore considered. The subtitle of Koers is Bulletin for C hristian Sc holarship. While the basis of Koers articles is Christian, room is left for justified differences of opinion.

Editing Functions: Standing, Local Institutional Spread, Intemational Participation, Peer Review, etc.

Consensus Review: The journal operates in the field of the relations between faith and science, and provides a kind of niche where scholars can publish in this field. The editor and the South African editorial associates have national, and some intema tional standing a mongst scholars within the world view of reforma tional philosophy. The list of faculty representa tives has been removed and a new editorial board, with fewer NWU representatives and more intemational representatives, has been in effect since 2010. Some of the overseas editorial associates are certainly well known and respected scholars, but most of them probably come from this same philoso phical tra dition as well.

Questionnaire: The journal has been published for 84 years without significant intemuptions.

In the period from 2006-2010, the number of published articles was 150 original articles, 21 letter-type articles and 97 reviews; in the same period 213 article manuscripts were received, giving an acceptance rate of about $70 \%$. Only a few manuscripts were rejected without peer review. About $18 \%$ of the papers had at least one author with a non-South African address. Three peer reviewers are usually approached for each submitted manuscript. About 97 reviewers were used, of whom about $20 \%$ had non-South African addresses. Peer review reports are all retained in records.

The interval between receipt of a manuscript and its publication in print is between three and nine months and on the web, a little longer. The publication 
frequency of the journal is four issues per year; not all issues appear on their given dates. Since 2012, the journal is published electronically, in open access mode, on a rolling publication basis. One edition, in hard copy (containing all contributions for that year) is published a nnually. In the case of special themed issues, a separate edition is published for each special issue. Also, as of 2012, all issues a ppear on their given dates.

The present editor, who has been editing the journal since 2008, was appointed competitively by the Koersvereniging (Society) for five years that can be extended. Members of the editorial board are also appointed by the Koersvereniging (Society) for a period which is reviewed every three years. Editorial board members are appointed from both inside and outside the country in order to provide specific topical expertise. They handle peer reviews of individual manuscripts, and advise on editorial polic ies and practices.

Editorial policy guidelines are published and the journal has a conflict of interest policy. The editorial policy guidelines have been aligned with ASSAf's National Code of Best Practice in Editorial Discretion and Peer Review. When it is necessary, errata are published. The journal contains editorials, topical reviews, book reviews, and correspondence on published articles as value-adding features. The percentage of pages in each issue that represents peer-reviewed original material is just under $80 \%$.

\section{Content Quality, Focus, Spread within Domain, Sample of Best Work in SA, Enrichment Features, etc.}

Consensus Review: Probably due to its rigorous peer-review system and careful editing, the artic les published in this joumal a re genera lly of good quality. The journal clearly distinguishes in each issue between research articles and other kinds of genres, which is an ind ic ation that the editorial process respects the integrity of peer-reviewed original research.

As an interdisciplinary journal that publishes articles from the fields of natural science and the humanities with philosophy as the bridge, the joumal attracts artic les from a wide spectrum of authors, and uses referees from across the board of scholarly academic activity. Because of this pronounced inter-d isc iplina rity, it is difficult to say whether the articles in this journal represent a good sample of the best work done in the country. It could be that those scholars who want to publish serious scholarly work for their peers will probably do that elsewhere, in their respective disciplinary joumals, and not here. For example, it could be argued that the theological pa pers published in Koersare ones that could not be published in ma instrea $m$ theology joumals, but that may not be a question of poor quality, rather of a new direction. There seem to be quite a number of philoso phic al a ric les written not by philosophers but by other scholars reflecting on the theoretical and worldview aspects of their own disciplines; when the authors concerned are well known in this country and elsewhere, this is not a bad thing.

The number of articles per annum at about 38, published in four issues, is low but reasonable in comparison with similar local joumals. The joumal seems to be on a par with other joumals in theology, the humanities and philoso phy. A broader spectrum of contributors, especially intemational aca demics, should, however, be pursued, and not only through publishing papers presented at intemational meetings.

The articles show a balance between global and local matters; philosophical research published in the joumal is mostly foc used on global issues, while articles exploring the relation between religion, culture and science have a more local flavour. The joumal may be able to expand its intemational foc us by initiating a global discourse about religion and science. 
Consensus Review: Editorials appear regularly and are published in both Afrikaans and English, usually focusing on the contents of the issue concemed. Publication wa s often behind schedule, but no issue is ever missed out. As of 2012, public ation is on schedule due to online publishing.

Book reviews are presented, as well as other value-adding features, such as commentaries on specific topics such as leadership or communication, but perhaps more international publications could be reviewed. Scholarly correspondence is lacking.

Every article has a proper English abstract, as well as a summary in Afrikaans.

No errata have been noted.

Over recent years the joumal has improved its technic al quality, so that the presentation and layout are now very neat and of high quality; the journal makes a good academic and scholarly impression. The style used is the abbreviated Harvard method of referencing, and this citation practice is good.

\section{Usefulness in Capac ity Development and Intemational Comparability}

Consensus Review: The overall impression is that the joumal stimulates sc hola rs and students to take part in a discourse about faith and science, or religion and society. The extent to which graduate students and young staff publish in the peer-reviewed section is not clear, however.

Not many international journals have the same philosophical focus and niche; compared with, for example, Philosophia Reformata in the Netherlands, this joumal would look quite good. International interest in the journal could be improved because the discourse about faith and science is currently a live and well.

\section{Suggested Improvements}

Consensus Review: The joumal has a particular nic he which is extremely relevant in the post-modernist interest in the relevance of religion; the journal should accordingly be encouraged to seek a more prominent international position, and the editorial board should do its utmost to make the journal a leading journal in the fa ith-science debate. Perhapsa brief description of the nature of the joumal and its ambitious aims could be included in each volume, in order to create a framework of understanding for a grea ter range of rea ders in many different disc ip lines.

\section{Business Aspects}

The journal's regular print run is 180 copies; it is published by V\&R Printing Works. As of 2012, the production services are handled by AOSIS and the distribution services are handled in-house. The joumal does not camy either paid or unpaid advertising, and receives no financial sponsorship.

The number of subscribers is 137; of these, 51 are organisations and 86 individuals.

The joumal appears online as part of a commercial e-public ation service.

The journal's total income per year is R60 000 and the total expenditure is R62 000. The joumal has never received offers to purchase from multinational publishers, but several offers to jo in other online publishers. The submission of a $n$ a ric le entitles Koers 
to exclusive right of public ation, in printed, electronic and other media. As of 2012, copyright resides with authors and articles are licenced under the Creative Commons Attribution License.

English abstracts are published for all articles. The editor would in principle be interested in the journal being considered for inclusion in ASSAf's SciELO-South Africa platform.

\section{Panel's Consensus View}

I. The joumal should continue to be listed on the DHET list of acc redited joumals. II. The publisher/ editorshould be invited to considerjoining the evolving ScieOSouth Africa platform.

III. The editor should seriously consider the recommendations provided in this review.

IV. In partic ular, the Panel believes that the joumal should energetically exploit its already established position as a niche joumal in the spaces between the natural science and the humanities, with philosophy as the bridge.

\subsubsection{TYDSKRIF VIR C HRISTEUKE WEIENSKAP/J OURNAL FOR C HRISTIAN SCHOLARSHIP}

Focus and Scope: The J oumal for Christian Scholarship is a DHET-accredited publication of Die Vereniging vir Christelike Hoër Onderwys (The Association for Christian Higher Education) in South Africa. It serves to provide scholars with an opportunity to publish articles with a Christian point of view, not necessarily in accordance with that of the Vereniging (Association), but (i) making a contribution to the enhancement of Christian scholarship, or (ii) engaging in discourse within the Christian scholarly tradition.

Editing Functions: Standing, Local Institutional Spread, Intemational Participation, Peer Review, etc.

Consensus Review. The editor has national standing in his field of study, namely the philosophy of law; he is also a frequent contributor to the journal itself (See below). The joumal is the property of the Vereniging virChristelike HoërOnderwys (Association of Christian Higher Education), but publishes articles more widely in the fields of philosophy, law, education and theology. The a ray of artic lesover the past three years does not indicate a specific niche, and also does not explicate the specific Christian paradigm it is intended to explore: the use of the concept 'Christian' is too general and the exposition of 'Christian Education' unclear. Their application actually seems to be limited to a very small pocket of Christian scientific studies. It seems that the journal operates in the domain of fundamentalist theology and philosophy; this impression is strengthened by the overuse of certa in authors and the absence of a ric les by prominent intemational scholars. The editorial board consists of three local members who are well respected, but mostly from one institution (UFS), and one international scholar; it should definitely be expanded - both nationally and internationally.

Questionnaire: The journal has been published for 45 years without significant intemuptions. Duning the three-year period under review, the number of published original articles was 51 in scheduled issues and 26 in special issues, with one book reviews. In the same period, 93 article manuscripts were received, a high acceptance rate of $83 \%$. No manuscript was rejected without peer review.

Eleven out of the 77 published articles had at least one author with a non-South Afric an address. One or two peer reviewers are usually approached for each submitted manuscript. In 2009, 45 peer reviewers were used, all South Africans. All peerreview reports a re retained in the records.

The average interval between receipt of a manuscript and its publication in print is approximately four to six months, and on the web five to seven months. The publi- 
cation frequency of the joumal is two to four issuesperyear, special editions excluded. The joumal issues are pre-sc heduled and nomally appear on the given dates.

The present editor, who has been running the joumal for the past seven years, was appointed competitively following a selection process. The appointment period is from time to time as decided by the executive board. Members of the editorial board are also appointed competitively following a selection process; the period of their appointment is not specified. They handle peer reviews of individual manuscripts, and advise on ed itorial polic iesand practices. The editorial board consists of members from inside and outside South Africa.

Editorial policy guidelines are published; conflicts of interest are handled by the editorial board. The joumal is in the process of a ligning its editorial polic y guidelines with ASSAf's National Code of Best Practice in Editorial Disc retion and Peer Review. Where they become apparent, errata are published. The joumal publishes topical reviews, book reviews and correspondence on published articles. The percentage of pages in each issue that represents peer-reviewed original material is nevertheless a pparently close to $100 \%$.

\section{Content Quality, Focus, Spread within Domain, Sample of Best Work in SA, Enrichment Features, etc.}

Consensus Review: The articles focus on local/regional kinds of materials/problems, including important issues such as worldviews, philosophical aspects conceming natural science, theological ethics, epistemology, ontological questions, education, law, and polemics. They apparently seek to create philosophical frameworks of und erstand ing with rega rd sto issues within a partic ular disc ipline, such as education, ethics, law, etc.

Despite the above, the artic les are generally of average quality and seldom reflect international standards. This state of affairs can probably be attributed to the fact that intemational referees are not used and that referees are often limited to less than two per article. It seems that the authors, including the editor, operate in a faily closed circle of communication, and do not engage in the intemational debates about the topics they wish to address. The joumal gives an impression of 'in-breeding' and a lack of specific engagement with open discourse.

The joumal is published regula rly, and several special editions have been published in addition to the normal editions. Taking into consideration the fact that some scholars publish regularly (sometimes with more than one article in a single issue), and that in many cases only one referee who in every instance is local, this state of affairs should be expected.

With a few exceptions, the work done is not on par with other journals nationally.

The artic les do not engage enough in active regional issues. Much can and should be done in this respect especially in the field of practical education where there are enomous challenges for research. The same can be said regarding the articles about ecclesiology and law.

The ed itor perso na lly publishes in litera lly every ed ition (three timesa year). Together with the fact that several other na mes a ppear repea tedly as authors, the independence of the joumal is in serious jeopardy.

The overall impression of the joumal is that it is very local, and that no attempt is made to make it more open, national or international, and that only a very limited number of people actually publish in the joumal. 
Consensus Review: In the issues of the joumal over the past three years, editorials, topical reviews and correspondence are lacking, while very little attention is paid to book reviews (i.e. one was published in the past nine issues).

Proper English abstracts are published with all articles in Afrikaans, while Afrikaans and English abstracts a re published with artic les in English. This practice impedes indexing. No publication errata could be found in the past ten editions.

The citation practice is acceptable. The journal uses the abbreviated Harvard method of citation and references. The presentation, la yout and style a re neat and well done, but the general technic al image of the joumal is out-dated and not on a par with other journals in the field of the humanities.

\section{Usefulness in Capacity Development and Intemational Comparability}

Consensus Review: Due to the limited scope of the joumal and its particular ideological paradigm, its suitability as a general on-going stimulus for local graduate students and young staff can be questioned.

The joumal falls short when compared with lead ing intemational jouma ls in the specific field of law, theology, philosophy and education; the problem is that a real comparison is not possible.

\section{Suggested Improvements}

Consensus Review: The joumal should broaden its focus by enrolling intemational scholars to serve on the editorial board and attracting papers from authors from abroad; expanding its paradigmatic scope to make it possible for more scholars to publish and to engage in critical reflection; broadening its list of contributors and peer reviewers; establishing policies for special peer review of articles by the editor and editorial board members; introducing rules for publishing book reviews and encouraging critical reflections; and improving the general image of the journal and changing its old-fashioned look.

\section{Business Aspects}

The journal is published by the Association for Christian Higher Education. Production is outsourced, while the distribution is handled in-house. The joumal does not carry either paid or unpaid advertising, and receives no financial sponsorship.

The number of paying subscribers is 71 , of whom about 15 are organisations as opposed to individuals. The journal is part of SABINET's commercial e-publication service. The journal's total income per year is R55 000, while total expenditure is R38 000. The journal has never received offers to purc hase from multina tional publishers. Copyright is vested in the Association for Christian Higher Education.

The journal is indexed in IBSS, and its ISI impact factor has never been determined. English abstracts and front deta ils are published for all articles. The joumal was previously independently peer-reviewed. The editor would in principle be interested in having the journal considered for inclusion in ASSAf's SciELO-South Africa open access platform.

\section{Panel's Consensus View}

I. The joumal should not continue to be listed on the DHET list of accredited joumals (despite its entitlement to this, under policy as an IBSS-indexed periodical). 
II. The publisher/ editor should not be invited to consider joining the evolving

III. The editor should seriously consider the findings and recommendations provided in this consensus review, especially those pertaining to quality assurance through effective independent, multiple peer review.

\subsection{Religious Studies}

\subsubsection{THEOLOGIA VIATORUM: J OURNALOF THEOLOGY AND REUG ION IN AFRCA}

Foc usand Scope: The editoria I committee of the above-mentioned joumal accepts contributions on any topic related to the fields of theology and religious studies, particularly those conceming the Afric an continent and its people. Interd isciplinary a rtic les a nd contextualised a na lyses are included.

\section{Editing Functions: Standing, Local Institutional Spread, Intemational Participation, Peer Review, etc.}

Consensus Review: The editor has national/regional standing, supported by an assistant editor from the same institution. The editorial committee is spread over six South African institutions, and the editorial board over three other African and two foreign institutions. They represent a good spread of expertise and perspective.

Questionnaire: The joumal has been published for 24 years, and has been accredited since 2003 (for 2004). There was a significant interruption between 2000-2004 due to lack of funds. Eighteen research articles were published between 2006 and 2008 , and 19 in the two issues for 2009. A total of 63 manuscripts were received in the period of 2006 to 2010, many of them received in 2008 for the special xenophobia issue in 2009. None of the manuscripts was rejected without review; the overall rejection rate wasabout $50 \%$. About $30 \%$ of published papers had at least one author with a non-South African address. Two peer reviewers are approached for each submitted manuscript, and 26 different reviewers were used in 2008 with the special issue. About $10 \%$ of reviewers had a non-South African address. Peer-review reports are retained in records.

The average period between receipt of a manuscript and its publication depends on how good the manuscript is. Mostly, if the article is received in a particular year, it is published in the same year if it is really good, but otherwise the year after, and, in some cases, an article way might wait for two to three years, depending on the number of re-writes it needs. The publication frequency is two issues per year, but between 2006 and 2007 it was one issue per year. The issues are not pre-scheduled to appear on a given date. Generally the editor tries to bring out one issue each in J une and November/December, but usually this does not happen.

The editor, who has been in this position since 1999, was a ppointed unanimously by the relevant faculty board of the University of Limpopo (UL), for an indefinite period. Members of the editorial board do not handle the peer review of individual manuscripts but they do advise on editorial policies/practices. They are not appointed competitively via advertisement, and no specific period is given for their appointment. They are also appointed only from inside the country to provide specific topical expertise.

Editorial policy guidelines are published as 'Notes for Contributors', and there is a conflict of interest policy. The editorial policy guidelines have been aligned with ASSAf's National Code of Best Practice in Editorial Discretion and Peer Review. Errata are published when the need a rises. The joumal conta ins ed ito ria ls as a value-adding feature and may in future also feature book reviews. The percentage of pages in each issue that represents peer-reviewed original material is over $90 \%$. 


\section{Content Quality, Foc us, Spread within Domain, Sample of Best Work in SA, Enrichment}

Features, etc.

Consensus Review: The articles are all in English, and are generally scholarly. Their content and format are of good quality. This tri-a nnual joumal has six to eight articles per issue, and about 18-22 articles per annum. The articles are a reasonable sample of good work done in this country in the target topic area, but the field has the potential to provide much more, espec ially if the catchment really were to apply to all of Africa, as suggested by the journal title. The focus is mostly South African, but some artic les deal with matters from other Afric an countries. Authorships are spread across South African institutions, but very few are from outside this country and continent.

\section{Essential Technical Features: English Abstracts, Enata, Citation Practice, Presentation}

Consensus Review: There are no value-adding features excepting for a brief introduction to the content by the editor. Abstracts are in English, and no errata were observed. The citation practice is adequate to good.

\section{Usefulness in Capacity Development and Intemational Comparability}

Consensus Review. The topics covered are thought-provoking and relevant (mostly), and would provide useful points of discussion and debate. The joumal may be a small player in a big continent, but it seems to represent a promising sta it to a bigger future role. Generally, the content is beginning to compare reasonably well intemationally.

\section{Suggested Improvements}

Consensus Review. Features such as opinion editorials, commentaries, and book reviews could be included with benefit. The journal needs to attract articles from other African countries and from further afield, perhaps using editorial board membership to widen participation by other countries. The peer-reviewer network should be widened and acknowledged in the journal itself on an annual basis.

\section{Business Aspects}

The journal's regular print run is 100-120 copies per issue, and it is published by the University of Limpopo. Both production and distribution are not outsourced. The joumal is scheduled to be published on an open-access basis from next year, subject to the approval of various stakeholder bodies. The editor has personally done everything on the production side, except for language editing, up to now. The journal does not carry either paid or unpaid advertising, and receives no financial sponsorship. The journal has only five individual subscribers, the rest are institutional. The joumal does not appea r online. Its total inc ome per a nnum is R40 000-R45 000, and the total expenditure includes about R 10000 printing cost; if layout, publishing and distribution were outsourced, the cost would go up to R120 000-R140 000. The journal has never received offers to purchase from multinational publishers. Copyright rests with the author and publisher.

The journal is not indexed in Thomson-Reuters-ISI or in Scopus, and no ISI-type impact factors have ever been revealed for the joumal. The joumal has never been reviewed before except by DHET for accreditation.

The editor would in principle be interested in being considered for inclusion in ASSAf's SciELO-South Africa open access journal platform. The journal is increasing in status, as is evident from the increased number of contributions that a re being received from international contributors and established SA researchers. An offer of online and print publication by AOSIS is being considered by the faculty at present; funding is the issue. 


\section{Panel's Consensus View}

\section{The joumal should continue to be listed on the DHET list of acc credited joumals. \\ II. The publisher/ editorshould be invited to considerjoining the evolving ScielO- South Africa platform.}

III. The editor should seriously consider the improvement suggestions listed above.

IV. In addition, the Panel believes that the joumal needs to be professionalised in having the editor's position advertised and filled competitively, for a set period, and to set up the editorial board on a similar basis.

V. A name change mightalso be useful, as few people could deduce the focus of the joumal from its present title.

\subsection{2}

\section{JOURNAL FOR THE STUDY OF REUGION}

Foc us and Scope: The J oumal for the Study of Religion is published twice a year, in March and September, by the Association for the Study of Religion in Southern Africa as a forum for scholarly contributions on topics of contemporary significance in the academic study of religion.

Editing Functions: Standing, Local Institutional Spread, Intemational Partic ipation, Peer Review, etc.

Consensus Review: The editor is a highly rated, public ation-productive and active scholar. No addresses a re given for the other members of the editorial board, but a Google search suggested they were mostly or all located in the editor's research centre at UCT. There are nine members of an international editorial advisory board, mostly drawn from universities in the USA, although two of them are from other South African universities and one again from UCT itself. It is a problem for the editors of a South African journal to be drawn largely from one institution.

Questionnaire: The journal has been published for 29 years, first as Religion in Southem Africa (1980-1987); latterly under its present name (1988 to date). There have been no intemuptions in publication. In the three-year period (2007-2009) under review, 31 articles were published (this number includes the five articles published in Volume 22 (2), 2009) out of a total of 53 artic les received (about eight manuscripts were rejected without peer review). This gives an acceptance rate of just under $60 \%$.

On average, five peer reviewers a re approached for each submitted ma nusc ript. In 2009, 37 peer reviewers were used, of whom about $60 \%$ had non-South African address. Peer-review reports are retained in records (a paper copy is filed, as well as an electronic archive). Approximately half of the 15 articles had a first author with an intemational address.

The average interval between receipt of a manuscript and its publication in print is approximately five months. The J oumal for the Study of Religion is published biannually. Issues are pre-scheduled to appear in March and September, and for the most part they appear on the scheduled dates.

The present editor has been in charge of the joumal for the last seven years, having been re-elected each year by the Association for the Study of Religion in Southern Africa. Members of the editorial board are invited to serve for an unspecified period on the board; they are appointed from inside and outside the country, in order to provide specific topical expertise. Editorial board members handle peer reviews of ind ividual manusc ripts and a lso give advice on editorial practices.

Editorial policy guidelines are published, but a conflict of interest policy is not formally stipulated. The editorial policy guidelines have been aligned with ASSAf's Na- 
tional Code of Best Practice in Editorial Discretion and Peer Review. Errata have not yet been published, as the need has never arisen.

The joumal does not conta in non-peer reviewed features such as editorials, news and views, topical reviews, book reviews, and correspondence on published articles. The percentage of pages in each issue that represents peer-reviewed original material is therefore $100 \%$.

\section{Content Quality, Foc us, Spread within Domain, Sample of Best Work in SA, Enrichment Features, etc.}

Consensus Review: The a rtic les vary in quality but are all interesting and relevant. There are no 'faith-based' items, or articles which are not empirical in nature. Most of the articlesare free-standing but one issue was devoted to the paperspresented at a symposium (guest-edited by three scholars not on the editorial board.) Generally, the artic les are competent but not highly original, and pay attention to meta-aspects of most South African religions. One can learn much about the topics covered, from reading the artic les or their abstracts, but there is much more in the field one would like to see rigorously explored, especially the interactions between religion and public policy.

There are only about 8-12 articles per annum, published in two issues; the symposium report alone contained eight articles; it is clear that the editors are choosy in turning down many submitted manuscripts. Considering the special and dynamic place of religion in contemporary South African society, the journal should surely attract many more and better critical articles in this field, both from within and from outside the country.

Generally, the journal focuses on local and regional kinds of materials.

\section{Essential Technical Features: English Abstracts, Enata, Citation Practice, Presentation}

Consensus Review: There are no potentia lly useful schola rly features such as editorials (except as introductory material in the guest-edited symposium issue), book reviews, correspondence or any other 'added-value' features. This is a great pity taking into account the potential vibrancy of discourse available.

There a re well-constructed good abstracts for all articles. No publication of errata was noted. The citation practice is good, consistent, complete and appropriate throughout. The layout is a dequate to good.

\section{Usefulness in Capacity Development and Intemational Comparability}

Consensus Review: In some ways, the joumal may well provide some good material for both undergraduate and postgraduate use, as local/regional exemplars and sources, but the joumal fails to convince as a comprehensive contributor to thinking and review of its important field, and is only beginning to be comparable with the best intemational competitors such asJ oumal of Religion, or Religion \& Religious Studies. All in all it is an exc ellent joumal.

We suspect most scholarly journals in the field are much like this, but are simply much more substantial in the volume and range of their papers. The religiously diverse South African society presents a huge scholarly challenge which should be producing many more papers, linked solidly to the political, social and economic domains. Few mainstream joumals would have all/most of their editors based at one institution.

\section{Suggested Improvements}

Consensus Review: This joumal is edited and produced with care, and contains 
interesting and significant articles. It is very important, however, that (i) the focus of the journal be specified more narrowly, preferably to South or Southern African aspects of the topic; (ii) every attempt is made to attract good articles that more fully document the contemporary situation of religion in South Africa and the region, and (iii) the editorial board functions more closely according to the ASSAf guidelines, specifically in respect of the periodic appointment of editors and members of the editorial board. The joumal would gain greatly from being enlarged to three-four times a year, with a concomitant increase in the number of articles, and presenting opinion-type editorials (some invited), book reviews, correspondence and other fea tures. The full a ddresses of all a uthors should be provided and contact deta ils of correspond ing a uthors a lso, plus dates of submission and of acceptance.

This joumal needs to be accessible free online to all potential users, as its concems and contributions are of wide interest in the nation.

\section{Business Aspects}

The journal's regular print run is 180-200 copies, and it is published by the Association for the Study of Religion in Southern Africa. The journal's printing is outsourced to Salty Print, and the distribution to EBSCO and Swet. The journal does not carry either paid or unpaid advertising; limited financial sponsorship is supplemented by research funds.

The number of paying subscribers is 120 , plus 40 who receive the joumal as members of the Association for the Study of Religion in Southern Africa. The primary subscribers consist of 20 individua ls and 100 institutions. The joumal will soon a ppear online as part of a commercial e-publication service, possibly ProQuest. The journal's total income per annum is R27 000 (from subscriptions and research funds, while the annual expenditure is R22 000 for production and postage plus R24 000 for the work of research assistants housed in the Institute for Comparative Religion in Southern Africa who assist with the joumal.

The joumal has not yet received offers to purchase from multinational publishers. Copyright is retained by the authors of articles in each case. All articles are in English and have abstracts. The joumal has been independently peer-reviewed before. The editor is not interested in being considered for inclusion in ASSAf's SciELO-South Africa open access joumal platform because of the pending arrangement with ProQuest.

\section{Panel's Consensus View}

I. The joumal should continue to be listed on the DHET list of acc redited joumals.

II. The publisher/ editorshould be invited to considerjoining the evolving ScielOSouth Africa platform.

III. The editor should seriously consider the recommendations provided in this consensus review.

IV. In addition, the Panel believes that the joumal should broaden its editorship across institutions, and greatly expand the authorship by enhancing its focus on local and regional matters in this important field.

\subsubsection{JOURNALOFCONSIRUC TIVETHEOLOGY: GENDER, REIGION ANDTHEOLOGY IN ARRCA} (Name changed to J OURNALOF GENDERAND REJGION IN AFRICA)

Foc us and Scope: The J oumal of Construc tive Theology seeks to promote dialogue and response not only within the academic theological community in Africa and beyond, but also with faith practitioners working on the ground to build a more just society in the region. These may include clergy, other c hurch professionals and laity across broad social spectrums, who seek to read their faith against the critical issues confronting society today. 


\section{Editing Functions: Standing, Local Institutional Spread, Intemational Participation, Peer Review, etc.}

Consensus Review: The ed itor and co-editor a re both from UKZN, as are two of the other eight members of the editorial board; the rest are senior academics, two from the University of South Africa (UNISA), two are from Zimbabwe and one from De Pauw University in the USA. They all appear to enjoy good scholarly reputations. The seven international representatives are from a variety of foreign countries; their role in running the joumal is not expla ined. It is a problem that so many of the editors of a South African journal in a significant field are drawn largely from one institution.

Questionnaire: The joumal has been published since 1996 without intemuption. The number of original peer-reviewed papers published during the period under review included 29 artic les, three letter-type articles and one book review. About 46 article manuscripts were received in the same period; about ten manuscripts were rejected without peer review. Eighteen papers had at least one author with a non-South African address. Usually, two peer reviewers are approached for each submitted manuscript, but only different 20 peer reviewers were used in each year, half of these with non-South African addresses. Peer-review reports are accessibly retained in the records. The average interval between receipt of a manuscript and its publication in print is one year. The publication frequency of the joumal is twice peryear. The issues are pre-scheduled to appear regula rly on scheduled dates.

The present editor has been in charge of the joumal for 12 years, and the associate editor for seven. Both these editors were not appointed competitively, and their appointment period was not defined. Members of the editorial board are also not appointed competitively, but serve for a given period. They are appointed from inside and outside the country, in order to provide specific topical expertise. Some members of the editorial board handle peer reviews of ind ividual manuscripts, and all advise on editorial polic ies/practices.

Editorial policy guidelines are published, while a conflict of interest policy is in the process of being developed. The editorial policy guidelines have been aligned with ASSAf's National Code of Best Practice in Editorial Discretion and Peer Review. Errata are published when they become apparent.

\section{Content Quality, Foc us, Spread within Domain, Sample of Best Work in SA, Enrichment Features, etc.}

Consensus Review: The artic les vary in qua lity but are mostly interesting and relevant. The focus on gender issues in Africa in relation is very marked, and not justified by the editorial policy statement on the purpose of the journal. Some articles amount to sophisticated sermonising and hint of ideology makes itself felt in many articles, which are directed towards changes in social mores and practical policy. Amongst issues covered are faith responses to experience of AIDS, gender and poverty in Africa, and also in the US (in the case of African Americans).

Some of the articles are free-standing but one double issue was devoted to a set of invited essays forming part of a taught course at UKZN, while a nother was a guestedited set of articles on a specific topic. Generally, the articles are competent but not highly original. One can leam much about the topics covered, from reading the articles or their abstracts, but there is much more to be covered in the field, and analogous fields mentioned in the editorial policy, that one would like to see rigorously explored, especially the interactions between the role of religion in gender and similar issues, and its relation to public policy.

There are about 15 articles per annum, published in two issues; the course-related issue contained ten essays. Considering the present narrow focus of the journal, the 
small number of artic les is perhaps understandable, but the scope should actually be much wider, and it also seems as though the numbers are inflated through the dedication of whole issues to special topics.

The present narrow focus of the journal on gender makes it likely that the published work represents much of what is being done in the country, but much that is important, and could be, is not covered. Widening this focus may elic it many more articles from active authors. Most of the articles have a clear focus on African/South African contents; while there is a particular emphasis on KwaZulu-Natal, scholars from other South African and international institutions are involved.

\section{Essential Technical Features: English Abstracts, Enata, Citation Practice, Presentation}

Consensus Review: There are no edito ria ls (excepting as introductory ma terial), few book reviews (one in three years), no correspondence or any other value-adding features - this is a pity. There are also no abstracts for articles, a serious failing; the use of a section called 'Introduction' in each article or essay, instead of an abstract, does not constitute acceptable practice. Some articles offer almost no discussion of the secondary literature concemed.

No errata were noted. The citation practice is good, consistent, complete and appropria te throughout. The la yout is adequate to good.

\section{Usefulness in Capacity Development and Intemational Comparability}

Consensus Review: In some ways, the joumal may well provide some good material for both undergraduate and postgraduate use, as exemplars and sources; widening the scope of artic les will enhance this. Many articles draw attention and stimulate reflection on important aspects of African society. The journal should stimulate students in a range of disciplines.

Most scholarly journals in this field are probably much like this one, but are simply much more substantial in the volume and range if their papers. Few mainstream jouma ls would have so many of their editors based at one institution. At present, the joumal is far away from being a leading intemational joumal.

\section{Suggested Improvements}

Consensus Review: The new title J oumal of Gender and Religion in Africa may well be more appropriate than the original title.

This joumal is edited and produced with care, and contains interesting and significant articles. It is very important, however, that (i) the spread of editorial board members be extended throughout the country; (ii) the focus of the journal be widened, preferably to include more analogous treatments of South or Southern African issues that could respond to constructive theology; (iii) every attempt is made to attract good free-standing articles from active scholars in South Africa, the region and internationally; and (iv) the editorial board functions more closely according to the ASSAf guidelines, specifically in respect of the periodic appointment of editors and members of the editorial board. The joumal would ga in greatly from presenting opinion-type editorials (some invited), book reviews, correspondence and other features. The full addresses of all a uthors and the contact details of corresponding a uthors must be provided, plus the dates of submission and of acceptance.

Technical matters such as introducing proper abstracts are a high priority. Valueadding features should be expanded.

This joumal needs to be accessible free online to all potential users, as its concems and contributions a re of wide interest. 


\section{Business Aspects}

The journal's regular print run is 200 copies, and it is published by the Centre for Constructive Theology. Both the journal's production and distribution are handled in-house. The journal does not carry either paid or unpaid advertising; however, it receives some kind of, as yet unquantified, financial sponsorship.

The journal has only 59 paying subscribers; 43 are organisations as opposed to individuals. The joumal does not a ppea ronline. Its a nnual total inc ome is a bout R21 000, while expenditure is about R27 000. The editor has in the past received offers to purchase from multinational publishers, but details remain confidential at this stage.

Copyright rests with the journal. Front details like titles, authors, addresses, and English abstracts a re not included in the articles. The editor would be interested in having the journal considered for inclusion in ASSAf's SciELO-South Africa open access joumal platform.

\section{Panel's Consensus View:}

I. The joumal should continue to be listed on the DHET listof acc redited joumals. II. The publisher/ editor should only be invited to join the evolving ScieO-South Africa platform, afterattention has been given to the recommendations listed above, and most or all of the suggested improvements affected.

\subsection{4}

\section{MISSIONALA: J OURNAL OF THE SOUTHERN AFRICAN MISSIOLOGICAL SOCIETY}

Foc us and Scope: Missionalia is the journal of the Southern African Missiological Society (SAMS). It also contains abstracts from a wide range of missiological journals.

\section{Editing Func tions: Standing, Local Institutional Spread, Intemational Partic ipation, Peer Review, etc.}

Consensus Review: From the one hard copy available to the reviewers (Volume 35(3), 2007), it was lea mt that the editor is joined on a three-person editorial committee by the general secretary and his deputy of the South African Missiological Society. (The international advisory board comprises fifteen scholars, most of professorial rank, based in seven European countries, three in the USA, one each in Japan and Argentina, and one from Africa (Rwanda). Concern can be felt about the small editorial committee and its ex officio nature and relation to SAMS. It is difficult to judge how much is contributed to the journal by the IAB.

Questionnaire: Missionalia is the only theological journal in Southern Africa that is dedic a ted to missiology as a scholarly disc ipline.

The joumal has been published for 37 years without significant interruptions. The number of orig inal a rtic les published during the three-yearperiod under review was 71 (out of 84 submissions) but there were 117 reviews (out of 117 submitted). Five manuscripts were rejected without peer review. About $40 \%$ of published papers had at least one author with a non-South African address.

On average three peer reviewers a re approached for each sub mitted ma nuscript. Only 12 reviewers were used in one year, which is remarkably low for the 20-25 manuscripts handled, at three reviewers per paper, indic ating the possibly undesirable multiple use of the same small number of reviewers. A third of the peer reviewers had non-South African addresses. All peer-review reports are accessibly retained in records. The average period between receipt of a manuscript and its publication in print is 18 months. 
The joumal publishes three issues per annum. The joumal issues are pre-scheduled to appear in April, August and November of each year; the journal has, however, fallen behind its schedule for the past few years. The new editor, who is a black woman and was appointed as from 2009, is busy wiping out the backlog.

The previous editor served for 17 years. While not appointed competitively, he was re-appointed for terms of three years at a time at business meetings of SAMS, which owns the joumal.

Members of the editorial board are also not appointed competitively, and their appointment period is not specified. They are appointed from inside and outside the country, in order to provide specific topical expertise. Editorial board members handle peer reviews of individual manuscripts and they are asked to assess the quality of one issue peryear.

Editorial policy guidelines are published in each issue. The inside cover conta ins the following information: "Missionalia is the journal of the Southern African Missiological Society (SAMS). It is published three times a year (April, August and November). Artic les published or abstracted in Missiona lia do not necessarily reflect the views of the editorial committee or of SAMS. Manuscripts submitted for publication are assessed by the panel of referees and the decision to publish is dependent on those referees' reports. On the basis of this, the editor tables a report on the journal to the annual congress of SAMS, to whom the editorial committee is accountable".

The sub-title of the joumal reveals its purpose as the So uthem Afric an J oumal of Missiology. It is a research joumal and therefore publishes only artic les that contribute new knowledge to the field; as a Southern African journal, it gives preference to contributions by Southern African scholars, and young African scholars are especially encouraged to submit articles. The journal has a conflict of interest policy for the use of the editorial committee.

All articles are refereed 'blind', i.e. all references to the author(s) are removed when the manuscript is sent to referees. Contributions submitted by editorial committee members are refereed by an outside panel of reviewers. No contributor, whether on the editorial board or not, will have more than one of his/her articles published in a particular year/volume.

The journal has followed most of the ASSAf National Code of Best Practice in Ed itorial Discretion and Peer Review Principles And Practice for some time. There are, however, a few aspects in which the joumal still needs alignment of its practice, such aspublishing a list of referees a nnually, a nd publishing the dates of receipt and acceptance of each article in the joumal.

The journal contains value-adding features such as editorials, book reviews, and news and views. The annual congress of SAMS, with its topics and speakers, is regularly announced in Missionalia as part of the front section. Topical reviews a re occasionally published, for example on a series of publications from specific German publishers. Correspondence on published articles is not published; when someone feels challenged, stimulated or aggrieved by the contents of an article and communic a tes that to the editor, he or she is invited to submit an article in response to the previousone.

The percentage of pages in each issue that represents peer-reviewed original material in past three years is a bout $90 \%$.

\section{Content Quality, Foc us, Spread within Domain, Sample of Best Work in SA, Enrichment Features, etc.}

Consensus Review: The overall quality of the articles is reasonable, and many of them are written in a readable and contemporary style. There are many papers 
that represent sound scholarly work but there are also many much weaker examples. The number of articles published is surprisingly high, suggesting weakness in the peer-review mechanism (See above comment on the paucity of reviewers used). The joumal is important for local church history and for an understand ing of the way in which different varieties of religious experience a re currently passed on to, and enjoyed by, vast numbers of people worldwide.

The focus of many articles is on issues relevant for Africa, and some specifically South African, contexts. More than $50 \%$ of the authors are South Africans, with the others ma inly from other Afric an countries.

\section{Essential Technical Features: English Abstracts, Enata, Citation Practice, Presentation}

Consensus Review: The journal publishes regular editorials, many book reviews, info mation about congresses, and sometimes collections of essa ys on a special topic . All artic les are accompanied by an English abstract plus ind ex words. No errata have been published. The citation practice is good.

\section{Usefulness in Capacity Development and Intemational Comparability}

Consensus Review: In general, the joumal is suitable as a lively and engaging ongoing stimulus for local gra dua tes and young staff, not only in the disciplines of missiology and local church history, but also many social science disciplines. The focus is not limited to mission practices among Christians.

It is a good and enterprising journal for the South African context, but nowhere near an intemational level.

\section{Suggested Improvements}

Consensus Review: The peer-review process needs to be overhauled to include a much greater variety and range of reviewers; in addition, the editorial committee should be enlarged and diversified, and become much more rigorous in accepting or rejecting articles. The IAB should be brought into a more active role in developing the joumal intemationally, and there should be more intemational peer reviewers, editors and contributors.

Public ations of issues should be more regular and on time.

\section{Business Aspects}

The regular print run of the journal is 600 copies; it is published by the Southern African Missiological Society. Both printing and distribution are handled in-house. The journal does not carry paid advertising; occasionally it advertises new publication by Southern African colleagues on a complimentary basis. It does not receive financial sponsorship.

The number of paying subscribers is 423, of whom 124 a re ind ividualsa nd the others institutions or orga nisa tions. The joumal d oes not a p pea r online. Its total income per annum is R86 000, while the total expenditure is R83 000.

The joumal has been approached by multinational publishers with offers to purchase, but the editor and publisher were not interested. Authors reta in copyright. All published artic les a re in English. English abstracts of each article a re published. The joumal has never been independently peer-reviewed before. The editorwould in principle be interested in the journal being considered for inclusion in ASSAf's SciELO-South Africa platform as a free online, open access journal.

\section{Panel's Consensus View}

I. The joumal should continue to be listed on the DHETlist of acc redited joumals. 

II. The publisher/ editor should be invited to join the evolving SciEO-South Af- rica platform, but this should depend on whether improvements in quality assurance, mainly based on more effective peer review and more rigorous editorial discretion by a largereditorial committee, have been implemented.
III. The editor should seriously consider the recommendations conceming inter- nationalisation of the joumal.

\subsubsection{STUDIA HISTORIAE ECCLESIASTICAE}

Foc us and Scope: Studia Historiae Ecclesiastic ae (SHE) publishes articles in the discipline of church history/history of Christianity, preferably with an African, and specifically, a South African, perspective. The focus is on articles that present new research in the field of (South) African ecclesiastical history, or offer substantial reinterpretation of already published research, including articles with a specific focus on gender, class and power and their manifestations through the centuries.

\section{Editing Functions: Standing, Local Institutional Spread, Intemational Participation, Peer Review, etc.}

Consensus Review: The journal is published through UNISA by the Church History Society of Southern Africa (CHSSA). The editor and co-editor are from UP and UNISA, respectively, and the editorial associates are from South Africa (4), the USA (3), and from Nigeria, Malawi, the Netherlands and Scotland ( 1 each). Their institutional addresses and academic titles are not provided. It is thus not possible to assess their scholarly reputations or standing, but the opinion has been expressed that they enjoy good national reputations, some perhaps also beyond the country's borders.

Questionnaire: The joumal has been published for 35 years without significant interruptions in publication. The number of published original artic les during the threeyear period under review was 125 articles and (remarkably) 185 reviews. In the same period, 407 manuscripts were received, presumably of both artic les and reviews, giving an acceptance rate of around $80 \%$. Approximately $25 \%$ of the manuscripts were rejected without peer review. About $10 \%$ of the published papers had at least one author with a non-South African address.

Usually the editor approaches four peer reviewers per submitted manuscript, of whom two or three usually agree; 64 peer reviewers were used in total, in the threeyear period. About $10 \%$ of these peer reviewers had non-South African addresses. Peer-review reports are accessibly retained in records. The average interval between receipt of a manuscript and its public ation in print is three to six months. The joumal is not a vailable on the web.

The journal is published in two issues plus a supplement, annually; these are prescheduled to appear in February, J une, and October. The issues appear regula rly on the scheduled dates.

The present editor, who has been running the joumal for four years, wasappointed competitively for a five-year period after nomination and election at the AGM of the Church History Society of Southern Africa.

In principle, members of the editorial board handle peer reviews of individual manuscripts, and advise on editorial policies/practic es. The membership of the editorial board, as well as policies related to the journal, are currently under review; the aim is that the new members will also act as an advisory board that evaluates issues of SHE after they have been published. The members a re appointed competitively for five years, after members of the CHSSA have been invited to present names that are put through a selection process via the AGM. Members are appointed mainly from inside the country to provide specific topical expertise. 
Editorial policy guidelines are published in each issue. The joumal has no written conflict of interest policy, but reviewers of artic les a re never chosen from the same institution as the author of a manusc ript. The editorial policy guidelines have been aligned with ASSAf's National Code of Best Practice in Ed itorial Disc retion and Peer Review. Errata would be published where the need arises.

The journal contains value-adding features such as editorials (See for instance the editorial on female genital manipulation in the first issue of 2009). While news and views only appear on the website, topical reviews are published in print. Book reviews are also published in print (the joumal has contacts with the main publishing houses of the world to send in books for review). Correspondence on published artic lesisencouraged. The percentage of pages in each issue that represents peerreviewed original material is $90 \%$.

\section{Content Quality, Foc us, Spread within Domain, Sample of Best Work in SA, Enrichment Features, etc.}

Consensus Review: Until five years ago, Studia Historiae Ecclesiasticae published mainly articles by a small group of academics within the sphere of Reformed Church history. Since then, its authorship and subject matter have been broadened to inc lude both male and female academic sfrom all races, belonging to a wide va riety of denominations and religions. During 2008, for instance, 48 articles were published of which 27 were by black scholars and 19 by women scholars (of whom 11 were black). The journal also engages in capacity building with developing scholars; for example, the review process allows for guidance to young researchers who are at the beginning of their academic careers.

The tone of the joumal is refreshingly contemporary and intellectually lively. Articles tend to be arranged and grouped in thematic sections in each issue, and in one issue, one theme only. They are mostly engaged and yet scholarly/empirical in approach and format. They include specific histories and biographies. The book reviews are astonishingly (for a South African journal) numerous and diverse, and mostly written by local authors; they take up nearly half the printed pages. A welcome and logic al degree of multi-disc iplina rity is evident.

There have been between 30-40 artic les per annum, published in two-three issues. This relatively large number of articles is impressive, and reflects good support by a particular scholarly community (But see below).

The focus of the joumal and the appreciably large scholarly community of local authors (and presumably readers) makes it likely that the published work represents a significant part of what could be produced in the country.

Many artic les display a local and contemporary focus. The authors a re drawn from a defined subset of South African institutions, however, with 8-14 authors in one issue (Volume 34 (2)) from either UNISA or UP. US, NWU and UKZN make up most of the rest, with a fair smattering of regional contributions, especially from Botswana. Very few authorscome from departments not located in theology/religious studies, history, etc. and none from conventional history departments. Church history has evidently not become part of integrated history, yet it needs to be. Social anthropology, political science, and organisational psychology a re all a rea s with a strong interest in church history; they are not (yet) participating in the life of this journal (except in some of the many book reviews).

\section{Essential Technical Features: English Abstracts, Enata, Citation Practice, Presentation}

Consensus Review: The book reviews are plentiful and highly readable, but there are no opinion' editorials, no correspondence or any other value-adding features. 
This is a pity. All artic les have English a bstracts. No publication of errata was noted. There is consistent, complete and appropriate citation practice throughout. The layout is excellent.

\section{Usefulness in Capacity Development and Intemational Comparability}

Consensus Review: The joumal provides some good exciting and relevant material for both undergraduate and postgraduate use, as exemplars and sources (and stimulus for reading new books!).

We suspect that many scholarly journals in this field are much less lively and engaged than this one. The Afric an focus is also valuable.

The jo umal is generally comparable in quality with the J oumal of Ecclesia stic al Studies, the J oumal of Theologic al Studies, and Church History, all of which however, are more traditional.

\section{Suggested Improvements}

Consensus Review: This joumal is edited and produced with care and evident enthusiasm, and contains interesting and significant articles, with a real feeling of engagement and modemity. The scope given to a rtic les by non-white, non-male a uthorsand young authors is commendable and should be encouraged. This is presumably a function of the use of double-blind reviewing processes, which makes for a strong journal and 'voice'. The failure to connect with scholars working in related ma instream disc iplines is to be deplored, however. It is very important that articles a re solic ited from universities and departments which despite having good scholars in the field have not yet contributed to the journal. The editorial board should function more closely in accordance with the ASSAf guidelines, specifically in respect of the periodic appointment of editors and members of the editorial board. The joumal would gain greatly from presenting opinion-type editorials (some invited), correspondence and other features. The dates of submission and of acceptance of individual artic les should also be provided.

This joumal needs to be accessible free online to all potential users, as its concems and contributions are of wide interest in the nation and beyond.

\section{Business Aspects}

The regular print run of the journal is just over 100, published by the Church History Society of Southern Africa. Printing is outsourced to the Pretoria Duplicating Company, while layout and distribution are handled by the secretary of the editor. The journal carries neither paid nor unpaid advertising. It also does not receive any financial sponsorship.

The number of paying subscribers is 110 , of which number 37 are organisations as opposed to individuals. The abstracts and book reviews appearfree online on the website www.unisa.ac.za/she. The journal's total income per annum is R126 000, while the total expend iture is R110 000.

The journal has had offers to purchase from multinational publishers. Copyright remains with CHSSA. The journal is indexed in ATLA Religion Database, published by the American Theology Library Association, Chicago.

English abstracts and front details are published. The joumal has never been independently peer-reviewed before. The editor would in principle be interested in the journal being considered for inclusion in ASSAf's SciELO-South Africa platform as a free online, open access joumal. 


\section{Panel's Consensus View \\ I. The joumal should continue to be listed on the DHET list of ac c redited joumals. \\ II. The publisher/ editorshould be invited to considerjoining the evolving ScielO- South Africa platform. \\ III. The editor should seriously consider the findings and recommendations brought fonward in this consensus review.}

\subsection{Specific Religious Traditions}

\subsubsection{JOURNALFOR ISLAMIC STUDIES}

Foc us and Scope: The J oumal for Isla mic Studies (J IS) is committed to the publication of original research on Islam as a world culture and civilisation, stimulating research that relates to religion, theology and law. It also seeks to cover the disciplines of history, culture, art, ethic s, politics, intemational relations, philosophy, history of religions, anthropology and sociology in the variety of ways in which these relate to the world of Islam in its broadest sense. This extends to comparative studies of soc ieties, as well as resea rc $h$ with an interd isc iplina ry and multi-d isc iplina ry foc us.

\section{Editing Functions: Standing, Local Institutional Spread, Intemational Participation, Peer Review, etc.}

Consensus Review. The editor and two other executive editors are all from UCT, while the advisory editorial board (AEB) comprises individual academics from UJ and the University of the Western Cape (UWC) in South Africa, one from the University of Botswana, six from the USA and one from Malaysia. They are all scholars of some distinction, as far ascan be detemined. The role of the AEB members in running the joumal is not explained. It is a problem that all of the executive editors of a South African journal are drawn from one institution.

Questionnaire: The journal has been published for 29 years without significant interruptions, but has some 'catch up' issues to address. The number of original peerreviewed papers published during the period under review was 19 artic les and two reviews; about 27 manuscripts were received in the same period, of which 11 were rejected without peer review. This suggests that virtually a ll pa pers a c tually subjected to peer review were accepted, not a good sign of rigour. Out of 17 published papers, 14 had at least one author with a non-South African address.

Usually, two peer reviewers are approached for each submitted manuscript. Approximately ten peer reviewers were used in one year, of whom eight had nonSouth African addresses. Peer-review reports are accessibly retained in the records. The average interval between receipt of a manuscript and its public ation in print is one year, and it is sent to AJ OL as soon as it has been published. The publication frequency of the joumal is one issue per year, not pre-scheduled to appear on a given date (the last two issues appeared in J uly in the respective years).

The immediate past editor, who has been running the joumal since 2006, was not appointed competitively but was asked to serve for three years by colleagues. Editorial board members are invited (not specified by whom, presumably by the editor) as specialists in the field to serve for five years. They are appointed from both inside and outside the country, in order to provide specific topical expertise. Editorial board members handle peer reviews of individual manuscripts. Some comment from time-to-time on editorial polic ies/practices.

Editorial policy guidelines are published, but there is no stipulated conflict of interest policy. The editorial policy guidelines have not been aligned with ASSAF's National Code of Best Practice in Discretion and Peer Review. Errata are published when they become apparent. 
The journal does publish value-adding features such as editorials, book reviews, and correspondence on published articles, but is not opposed in principle to publishing topical reviews. The percentage of pagesin each issue that representspeer-reviewed original material is 100\%, excepting for book reviews.

\section{Content Quality, Focus, Spread within Domain, Sample of Best Work in SA, Enrichment Features, etc.}

Consensus Review: The a ric lesvary in qua lity, and some a re perilously close to what one might call 'faith-bound' rather than scholarly in nature. Most of the articles are rightly Africa-focused. Some of the articles deal with various challenges to religious practice: conceming women, divorce, local history, youth, etc. In principle, the journal offers a stimulating choice of topics. Authors come from South Africa and from a variety of countries (Nigeria, Turkey, Canada, Holland, etc.).

Most articles are free-standing, but one issue (2008) was devoted to a set of articles on gender relations in Muslim Africa. There is much to be leamt from the topicscovered, from reading the articles or their abstracts, but there is surely much more in the field that one would like to see rigorously explored, taking into account the importance of Islam in African countries and regions, and the many and deep issues raised by developments in an era characterised by globalisation and accelerating technological change. In fact, reading the papers gives one the impression that time is somehow assumed to stand still, or nearly so, in many contexts of society, political conflict, and insights into the human condition.

There are a half-dozen or less articles per annum, published in one issue. Considering the huge significance of Islam in the world at this time, the small number of artic les is und erstandable only in terms of a small scholarly community, but this would reflect a narrowing of that community to its immediate practitioners, rather than to a broad community of scholars in different disciplines who should be encouraged to turn their gaze to Islamic matters. Such an editorial policy would enhance the impact and scope of this joumal, and sharpen the arguments in its pages.

Widening the scholarly focus will elic it many more artic les from active authors in many fields; as an example, the book review by a Muslim surgical researcher was refreshing to read.

The articles focus on local and regional kinds of materials. The small number of authors is drawn from several South African institutions, with a few from outside the country.

\section{Essential Technical Features: English Abstracts, Enata, Citation Practice, Presentation}

Consensus Review: The book reviews are excellent and add much value to the journal's pages. There are, however, no editorials (excepting as introductory material for specially collected articles), no correspondence or any other value-adding features - this is a pity.

English abstracts for all artic les are published. No public ation of errata was noted. The citation practice is good, consistent, complete and appropriate throughout. The layout is adequate to good.

\section{Usefulness in Capacity Development and Intemational Comparability}

Consensus Review: In some ways, the joumal may well provide some good material forboth undergraduate and postgraduate use, asexemplarsand sources. Widening the scope of articles in tems of authorship and scope will enhance this. 
We suspect most regional scholarly journals in the field are much like this, but presumably they are much more substantial in Muslim-majority countries. The special interest of Africa in the context of Islam is not well illustrated by thisjoumal, although it is a start.

\section{Suggested Improvements}

Consensus Review: This joumal is edited and produced with care, and contains interesting and significant articles. It is very important, however, that (i) the spread of executive editorial board members be extended throughout the country; (ii) the disciplinary focus of the joumal be widened, preferably to include more papers from outside the immediate small community of Islamic scholars; (iii) all faith-based content is carefully analysed and excised or rejected; and (iv) the editorial board functions more closely according to the ASSAf guidelines, specifically in respect of the periodic appointment of editors and members of the editorial board. The journal would gain greatly from presenting opinion-type editorials (some invited), correspondence and other features. The full addresses of all authors and the contact deta ils of corresponding a uthors must be provided, plusthe dates of submission and of acceptance.

This joumal needs to be accessible free online to all potential users, as its concems and contributions are of wide interest in the nation. Subject to improvements along the above lines, it should be in the newly established SciELO-South Africa collection, and accredited by the Department of Education in terms of its research outputs policy.

\section{Business Aspects}

The journal's regular print run is 250 copies, and it is published by the Centre for Contemporary Islam. Both the journal's production and distribution are handled inhouse. The joumal does not camy eitherpaid or unpaid advertising, and appears to receive no financial sponsorship.

The journal has 47 paying subscribers; 20 of these are organisations as opposed to individuals. The journal appears online as part of AJOL's non-commercial e-publication mecha nism. Its a nnual total inc ome is R25 000, while expenditure is R30 000 . The editorhas in the past received offers to purchase from multinational publishers.

The joumal uses AJ OL, but copyright belongs to the joumal. English abstracts for all articles are mandatory. The journal is indexed by SABINET; American Theological Library Association (ATLA); and an application is pending for inclusion in Thomson Reuters-ISI. The editor is not interested in being considered for inclusion in ASSAf's SciELO-South Africa open access journal platform because the journal depends on subsc niptions for inc ome.

\section{Panel's Consensus View}

I. The joumal should continue to be listed on the DHET list of accredited joumals.

II. The publisher/ editorshould be invited to considerjoining the evolving SciEOSouth Africa platform.

III. The editor should seriously consider the recommendations listed above.

IV. In partic ular, the Panel believes that the joumal needs to broaden its appeal to non-Islamic scholars interested and working in this and related fields.

\subsubsection{NIDAN: INTERNATIONALJ OURNAL FOR THE STUDY OF HINDUISM}

Focus and Scope: Nidan is a journal for the study of Hinduism, edited by Prof P Kumar (University of Kwa-Zulu Nata I). Artic les published in Nidan relate to a ny aspect of Hinduism, broadly conceived to include, not merely, the traditionally recognised 
areas within the discipline, but also contributions from scholars in other fields who seek to bring their particular worldviews and theories into dialogue with Hindu studies. Nidan serves not only the academic community, but is also a useful reader for the community on various themes and topics on Hinduism, and as such, assisting in educating the community in its own tra ditions, practices and philosophies.

\section{Editing Func tions: Standing, Local Institutional Spread, Intemational Partic ipation, Peer Review, etc.}

Consensus Review: In 2010, only five persons are listed as local editors, comprising two joint editors (apparently from UKZN), a senior editor from UKZN, and two members of the local editorial board (from UNISA and UCT). There are ten members of an intemational editorial board (IAB), drawn from major universities in a variety of countries, Japan, Hawaii, USA, Australia, etc. No information on the research standing of the local scholars specifically in Hinduism studies is provided, but the field is small in this country and they are presumed to be amongst the few scholars who are active in it. The members of the editorial board are seemingly not very much involved in the peer-review processes, as only four peer reviewers, all of them South African, were working in the whole period (See below).

Questionnaire: The journal has been published without significant interruptions for 22 years. The number of published original articles was 11 in 2008, seven in 2009, and seven in 2010, thus 25 in total for the three years. In the same respective years, 13 (2008), ten (2009), and nine (2010) manuscripts were received, a total of 32 papers. The acceptance rate was thus disturbingly just under $80 \%$; since seven manuscripts were rejected without peer review, it seems that all the papers that were peerreviewed were accepted, again surprisingly.

About $80 \%$ of the published papers had at least one author with a non-South African address. Usually, two peer reviewers a re approached per submitted manuscript, but only four reviewers were used in one year (for 7-11 papers). None of the peer reviewers had non-South African addresses. Peer-review reports are accessibly retained in the records. The average interval between receipt of a manuscript and its publication in print is three months. The joumal is published once per year. The joumal issues appear regularly on prescheduled dates.

The present editor, who has been in charge of the journal since 1998, was appointed (not known by whom), after nomination, for an indefinite period. Members of the editorial board are also appointed following peer recommendation and nomination, usually for three to five years. They handle peer reviews of individual manuscripts (But see comments a bove), and give advice on editorial polic ies and practices. The editorial board consists only of South Africans; all members of the board and the IAB are selected for their expertise in South Asian studies.

Editorial policy guidelines are published. The editorial board usually makes the editor a ware of its conflict of interest policy. The editorial policy guidelines have been aligned with ASSAf's National Code of Best Practice in Editorial Discretion and Peer Review. The joumal also followsthe generally accepted European guidelines. Errata a re not published. The joumal publishes ed itorials, but not regula rly. All pa ges of the joumal in each issue represent peer-reviewed original material.

\section{Content Quality, Foc us, Spread within Domain, Sample of Best Work in SA, Enrichment Features, etc.}

Consensus Review: The artic les vary consid era bly in qua lity, several a re fa ith-bound and not scholarly in nature, and some are downight poor, including contributions that are by non-scholars. Impressions, drawn from the small sample of articles in the three years reviewed, are that the handful of senior non-South African (international) authors a re dogmatic, assertive and long-winded, while the foreign student 
authors tend to be more original despite their less-established status. Local a uthors tend to examine sociological/anthropological aspects of Hinduism, or interpretations of the classical writings; overall, these are the papers that have the best quality. One learns much about Hindu affairs from reading the articles or their abstracts, but there is much more one would like to know and to see rigorously explored.

There are about six to ten articles per annum, published in a single issue. Considering the special place of the Hindus in contemporary South African society, punching well above their weight, so to speak, and the rise of predominantly Hindu India in the modem world, a joumal that purports to be "an intemational joumal for the study of Hinduism" should surely attract more and better articles in this field, both from within and from outside the country.

The same considerations as in the previous paragraph apply; there should be many more a ric les from a c tive authors.

Despite this being an 'international' journal, the more difficult and challenging questions in the field are not being addressed.

Authors are mainly drawn from UKZN, with a few from other South African universities or regional institutions, such as the University of Botswa na.

The focus in some articles is on South Africa, while others focus on Hindu teaching. Over the last three years 13 contributions out of 24 were by authors from outside South Africa.

\section{Essential Technical Features: English Abstracts, Enata, Citation Practice, Presentation}

Consensus Review: The only a dd itional sc hola rly features a re intro ductory ed itoria ls describing the articles to follow in an issue; there are no book reviews, correspondence or other features. Eng lish a bstracts were missing from some a rtic les in ea rlier volumes. No publication of errata was noted. The citation practice is reasonably consistent, but many outdated references are used by authors, while the layout is adequate. Copy-editing is poor and leaves many errors in the text, both with respect to wordsand format.

\section{Usefulness in Capacity Development and Intemational Comparability}

Consensus Review: In some limited ways, the joumal may well provide some material for both undergraduate and postgraduate use, as exemplars and sources, but the journal fails to ignite interest as a significant contributor to thinking and review of its field.

One suspects most scholarly journals in this field are similar to this journal, just much more substantial and well edited; one certainly doubts that scholars in India would take this journal very seriously.

\section{Suggested Improvements}

Consensus Review: This joumal is edited, but not produced with care, a nd it is very important that (i) the copy-editing is improved; (ii) articles that are faith-bound and not empirical are rejected or severely edited; and (iii) every attempt is made to attract good articles that more fully document the contemporary situation of Hinduism and Hindus in South Africa and the region. In fact, there seems to be no real purpose in calling the journal "international" when it could become more focused, effective and intemationally relevant if it restric ted itself to fully covening its important field in Southern Africa. Rigorous peer review by a much larger variety of experts is needed to ensure quality, and to escape from what may seems to be a small, possibly in-bred group of authors submitting manuscripts. The joumal would gain 
greatly from being enlarged to twice (or three times) its size in number of betterquality a rtic les, a ppearing twice or three times a year, and presenting opinion-type editorials (some invited), book reviews, correspondence and other features. The full a ddresses of all authors should be provided and contact details of corresponding a uthors a lso, plus dates of submission and of acceptance.

This joumal needs to be accessible free online to all potential users, as its concems and contributions are of wide interest in the nation.

\section{Business Aspects}

The regular print run of the journal is 100 copies; it is published by the University of KwaZulu-Natal. Both production and distribution are handled in-house. The joumal does not camy either paid or unpaid advertising. The joumal does not receive any financial sponsorship.

All university libraries in South Africa subscribe to the journal, which appears online on SABINET's commercial e-publication service (pay-to-view or subscribe). The journal's total income per annum is R $12000-R 15000$, while the total expenditure is about R10 000.

The joumal has not yet received offers to purchase from multinational publishers. The joumal holds copyright to articles published in it. Publication is only in English; abstracts and front details a re published for all articles. The joumal was previously independently peer-reviewed. The editor would be interested in an invitation for the journal to join the ASSAf SciELO-South Africa open access platform.

\section{Panel's Consensus View}

I. The joumal should notcontinue to be listed on the DHETlistofaccredited joumals.

II. The publisher/ editor also should not be invited to join the evolving ScieOSouth Africa platform.

III. The editor should seriously consider the findings and recommendations made in this review, in order to strengthen its contribution to scholarship in an important niche.

\subsubsection{INTERNATIONALJOURNALFOR REJGIOUS RREDOM}

Focus and scope: The IntemationalJ ouma I for Religious Freedom (IJ RF) is the joumal of the Intemational Institute for ReligiousFreedom (IIRF). It a ims to provide a platform for scholarly discourse on the issue of religious freedom in general and the persecution of Christians in particular.

\section{Editing Functions: Standing, Local Institutional Spread, Intemational Participation, Peer Review, etc.}

Consensus Review: The journal's address is given as Cape Town, but it appears to function as an intemational periodical, published on beha If of the IIRF of the World Evangelical Alliance, an organisation with offices in Germany, South Africa and Sri Lanka. It publishes articles and other kinds of items on a biannual basis. The editors a re respectively director and co-director of the IRF, and the honorary editor is a Iso closely associa ted with it. The intemational a dvisory boa rd comprises about 16 people drawn from institutions all over the world; about half of them have professorial titles and they mostly appear to be people of a very clear evangelical background.

It is a problem for a joumal to have two editors directly associated with the publishing organisation, without any indic ation as to possible (competitive) tumover of both editors and members of the board. There is a real risk of the journal being (or becoming evermore) agenda-driven. 
Questionnaire: The journal has been published for five years. There have been no significant interruptions in publication. There have been 38 research articles of which ten are in the latest issue, 14 letter-type articles, and two reviews; 75 manuscripts were received in the period, providing an approximate rejection rate of $33 \%$, although the editor sta tes that a bout ten manuscripts were rejected. Approxima tely $90 \%$ of published papers had at least one author with a non-South African address. Two to four peer reviewers a re a pproached for each submitted manusc nipt, 45 reviewers were used in all. About $80 \%$ of reviewers had a non-South African address. Peer-review reports are retained in records.

The average period between receipt of a manuscript and its public ation is about four months, and for publication on the web, about six months. The public ation frequency is two issues peryear. The issues are roughly pre-scheduled to appear on a given date within a margin of four to six weeks.

The editor has been in this position since 2008 when the journal was founded, and was appointed as founding editor for an indefinite period. Members of the editorial board handle the peer review of individual manuscripts, but not exclusively, and they advise on editorial policies/practices. They are appointed competitively via advertisement, and a two-year period is given for their appointment. They are appointed from inside and outside the country, in order to provide specific topical expertise.

Editorial policy guidelines are published, in so far as the 'Notes for Contributors' are concerned, and there is a conflict of interest policy. The editorial policy guidelines have been aligned with ASSAf's National Code of Best Practice in Editorial Discretion and Peer Review'. Errata are published, but are rare. The joumal contains valve-adding features and a 'Newsworthy' section, and there is occasionally some correspondence on published artic les. The percentage of pages in each issue that representspeer-reviewed original material, accompanied by an editorial, hasbeen $70 \%$ in the last year (latest two issues).

\section{Content Quality, Focus, Spread within Domain, Sample of Best Work in SA, Enrichment Features, etc.}

Consensus Review: The articles vary greatly in both in nature and quality; some, but only some, are undoubted ly interesting and releva nt sc hola rly a na lyses of problems in the chosen field of focus. That focus is on religious freedom generally, but particularly on persecution of Christians; one may want to think a little about the suita bility of such a special pre-occ upa tion for a sc hola rly joumal purporting to use only empinical approaches to its topics. A number of articles and features regrettably bear the hallmarks of faith-based advocacy, with a 'preachy' quality, while some features, a nnouncements and pronouncements a re not suitable for an academic joumal. Most of the academic artic lesare in an appropriate format, and do appear to examine issues that are significant in an objective manner.

One might prefer to see the important topic of religious freedom explored, in a multi-disciplinary manner, in jouma Is that have not quite so clearly nailed their colours to the mast, as it were. One can indeed be distinctly uncomfortable with the context and approach of the JIRF.

There are only about six to eight academic artic les per annum, published in two issues. Considering the present narrow focus and agenda of the journal, the small number of articles is perhaps understandable, but the scope should actually be much wider to include all aspects of religious freedom without the qualification of a focus on persecution of Christians.

The journal does not really have a focus on South/Southern Africa, and few/none of the articles have been written by authors associated with South African institutions. 
The Cape Town office of the IRF is simply the base of a journal with a full (international) focus on countries where religious freed om is endangered.

No authors are drawn from South African institutions, and no local connections seem to have been made.

\section{Essential Technic al Features: English Abstracts, Enata, Citation Practice, Presentation}

Consensus Review: There are introductory editorials and book reviews, but no academic comespondence. Most of the value-adding features are simply advocacy for the IRF and itsmission. There is a section on recent developmentsand documentation interviews.

The artic les have both ed itorial comment and an abstract. No public a tion of errata was noted. The citation practice is so und, with consistent and appropriate practice throughout. The layout is a dequate to good.

\section{Usefulness in Capacity Development and Intemational Comparability}

Consensus Review: The joumal ma y well provide some material for both und ergraduate and postgraduate use, as exemplars and sources, but the clearadvocacy of the IRF, and the dominance of its directors in authoring artic les, lessens its potential value and impact, as does the particular emphasis on Christian suffering.

The journal is too obviously associated with a clearly defined mission and agenda, and is impaired in its scholarly usefulness by the lack of independence and the inclusion of a particular sectarian emphasis in the field of focus.

\section{Suggested Improvements}

Consensus Review: This joumal is edited and produced with care, and contains some interesting and significant articles. No data have been provided on manuscript acceptance rates and the basis for editorial decisions. It is very important for the demonstration of genuine scholarliness on the part of this potentially important journal that (i) editorship be extended beyond officials of the publishing organisation; (ii) the spread of editorial board members be extended to this country; (iii) the focus of the joumal be widened to remove its special emphasis on the persecution of Christians and; (iv) every attempt is made to attract good free-standing articles from recognised scholars in South Africa and the neighbouring region; and ( $v$ ) the editorial board functions more closely according to the ASSAf guidelines, specifically in respect of the periodic new appointment of ed itors and members of the editorial board. The full a ddresses of all authors and the contact details of corresponding authors must be provided, plus the dates of submission and of acceptance. The la yout and typography of the joumal could be improved.

\section{Business Aspects}

The journal's regular print run is 1000 copies per issue, and it is published by AcadSA Publishing. Production is outsourced; distribution is done by the Intema tional J oumal of Religious Freedom. The joumal camies both paid and unpaid advertising. The journal received financial support for the previous issues but with the last issue it was self-supporting. The journal has about 60 paying subscribers; over 50 of these are organisations as opposed to individuals.

The joumal appears online on the joumal website and articles are in PDF. It is a Iso part of a commercial (pay-to-view) through SABINET. The journal's per annum total income is R60 000 and total expend iture is R60 000. The joumal has never received 
offers to purchase from multinational publishers. Authors keep copyright of their artic les.

The journal is not indexed in Thomson Reuters-ISI and Scopus, and no ISI-type impact factors have ever been determined for the joumal. Articles are only in English. The journal has been reviewed before by ASSAf.

The editor would in principle be interested in being considered for inclusion in ASSAf's SciELO-South Africa open access journal platform. (See the Frequently Asked Questions (FAQs) on the Intemational J oumal for Religious Freedom.) English abstracts a re published if a rtic les are not in English.

\section{Panel's Consensus View}

I. The joumal should not be listed on the DHET list of accredited joumals because of the limitation placed on its title-indicated scope by the focus on a particular faith, in a world where religious freedom has a much broader significance.

II. The publisher/ editor should not be invited to consider joining the evolving SciElO-South Africa platform.

III. The editor should seriously consider the strong recommendations made above conceming the foc us of the joumal, with consequential implications for editing, peer review, spread of authorship, etc ., plus a greater connection with South African scholarship in this field.

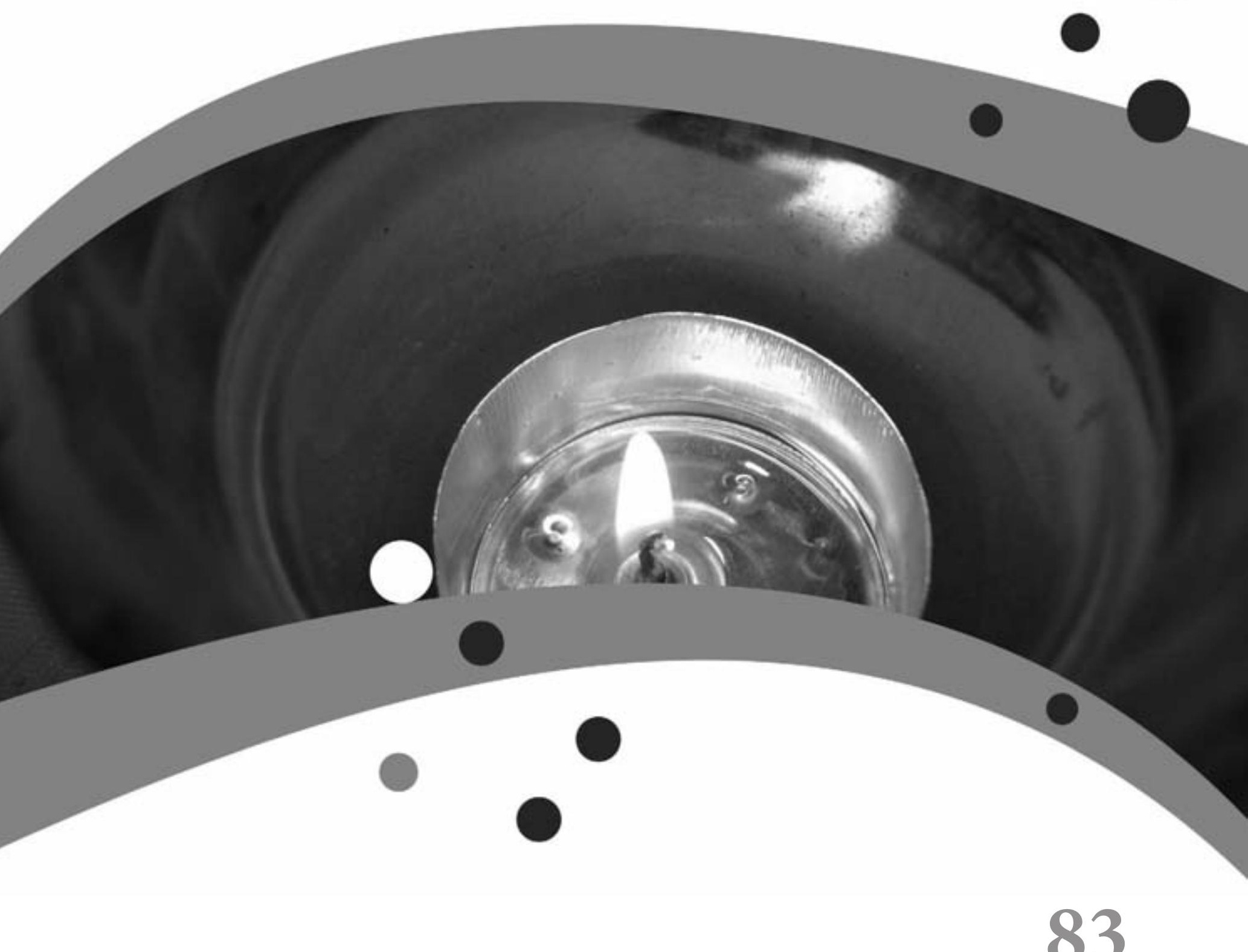




\section{Appendix A: Questionnaire sent to Each Editor of J oumals being Peer Reviewed}

Please type in a short answer, just after each question, and send us your consolidated response as an MSWord doc ument

\section{Editorial Process-related C niteria (generally based on the National Code of Best Practice in Edi- torial Discretion and Peer Review developed by ASSAf)}

- For how many years has your journal been published?

- Have there been significant interruptions in publication?

- How many peer-reviewed original papers have you published during the last three years: Articles?

Letter-type articles?

Reviews?

- How many manuscripts (of all three types) were received in the same period?

- Approximately how many manuscripts of all three types were rejected without peer review?

- What proportion of pa pers of all three types that you published had at lea st one a uthor with a non-South African address?

- How many peer reviewers are usually approached for EACH submitted manuscript?

- How many peer reviewers were used in total, in any ONE of the last three years?

- What proportion of these had non-South African addresses?

- Are peer-review reports accessibly retained in your records?

- What is the average period between receipt of a manusc ript and its public ation. In print?

On the web?

- What is the publication frequency of your journal, per year?

- Are issues of your journals pre-scheduled to appear on given dates?

- If scheduled, do the issues in fact appear regularly on the scheduled dates?

- How long have you been editor/chief editor of this journal?

- Were you appointed competitively (i.e. following advertisement and a selection process)? For what period?

- Do members of your editorial board Handle peer review of individual manuscripts? Advise on editorial policies/practices?

- Are they appointed competitively (i.e. following advertisement and a selection process)? For a given period? From inside and outside the country? To provide specific topical expertise?

- Do you have published editorial/policy guidelines?

- Is there a conflict of interest policy? 
- Have your editorial/policy guidelines been aligned with the ASSAf National Code of Best Practice in Editorial Disc retion and Peer Review?

- Do you publish errata in all cases where these have become apparent?

- Does your joumal conta in value-adding features such as

Editorials?

News and views?

Topical reviews?

Book reviews?

Correspondence on published articles?

- What is the percentage of pages in each issue that represents peer-reviewed original material?

\section{Business-related Criteria}

- What is the regular print run of your journal?

- Who is the publisher?

- Is production and distribution outsourced?

- Do you camy advertising which is

Paid?

Unpaid?

- Do you receive financial sponsorship(s)?

- What is the number of paying subscribers?

- How many of the subscribers are organisations as opposed to individuals?

- If your joumal appears online, Is it free online (open access)?

Is it part of a commercial (pay-to-view and/or pay-to-subscribe) e-publication service?

Is it part of a non-commercial e-publication mechanism (e.g. Medline)?

- What is your journal's (average) total income per annum?

- What is your journal's total expenditure per annum?

- Have you had offers to purchase from multinational publishers?

- What are your copyright arrangements?

\section{Bibliometric Assessments}

- Is your journal indexed in Thomson Reuters-ISI and/or the IBSS?

- Have ISI-type impact factors (e,g, Google Scholar or Scopus) ever been determined for your journal?

- If articles are not in English, are front details like titles, authors, addresses and English abstracts mandatory?

- Has your journal ever been independently peer-reviewed before? 


\section{General}

- Would you (and our publisher) in principle be interested in being considered for inclusion in ASSAf's proposed SciELO-South Africa as a free online, open access journal ( project description recently circulated to all editors)?

- Have you any other information or comments that may be useful to the Panel?

\section{Appendix B: Requests to Independent Peer Reviewers}

1. Do the hard copies of the last two to three years of issues of the journal reflect:

1.1 High national/international disciplinary reputations/standing of the editor-in-chief/associate editors/members of the editorial board?

1.2 A high/good (general/average) quality of the articles ccepted/published?

1.3 A (contextually) adequate/good number of articles per annum?

1.4 An (adequate/good) sample of the best work done in the country in the discipline/field?

1.5 A focus on local/regional kinds of materials/problems?

1.6 Publication of articles by authors from across the country, and internationally?

1.7 Useful additional scholarly features like editorials, topical reviews, book reviews, scholarly correspondence, etc.?

1.8 Proper (English-language) abstracts for all articles?

1.9 Suitable publication of emata?

1.10 Good citation practice?

1.11 Good presentation, layout, style and copy-editing interventions?

1.12 Suitability as a general on-going stimulus for local graduate students/young staff in the discipline concerned?

1.13 Some kind of comparability with leading international journals in the field?

2. Please list your suggestions for an improvement programme for the journal?

\section{Appendix C: Bibliometric Profile of South African Religious Study Journals}

A statistical report by:

The Centre for Research on Evaluation, Science and Technology (CREST) Stellenbosch University
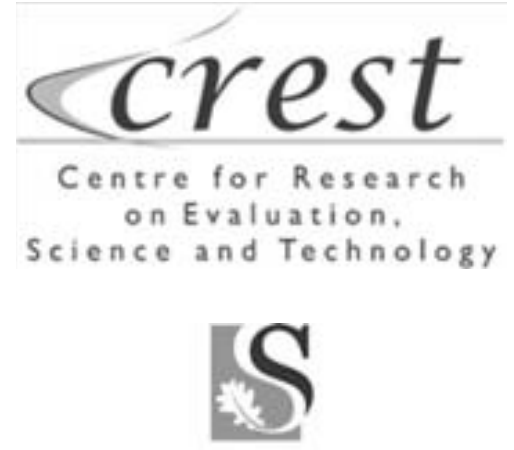


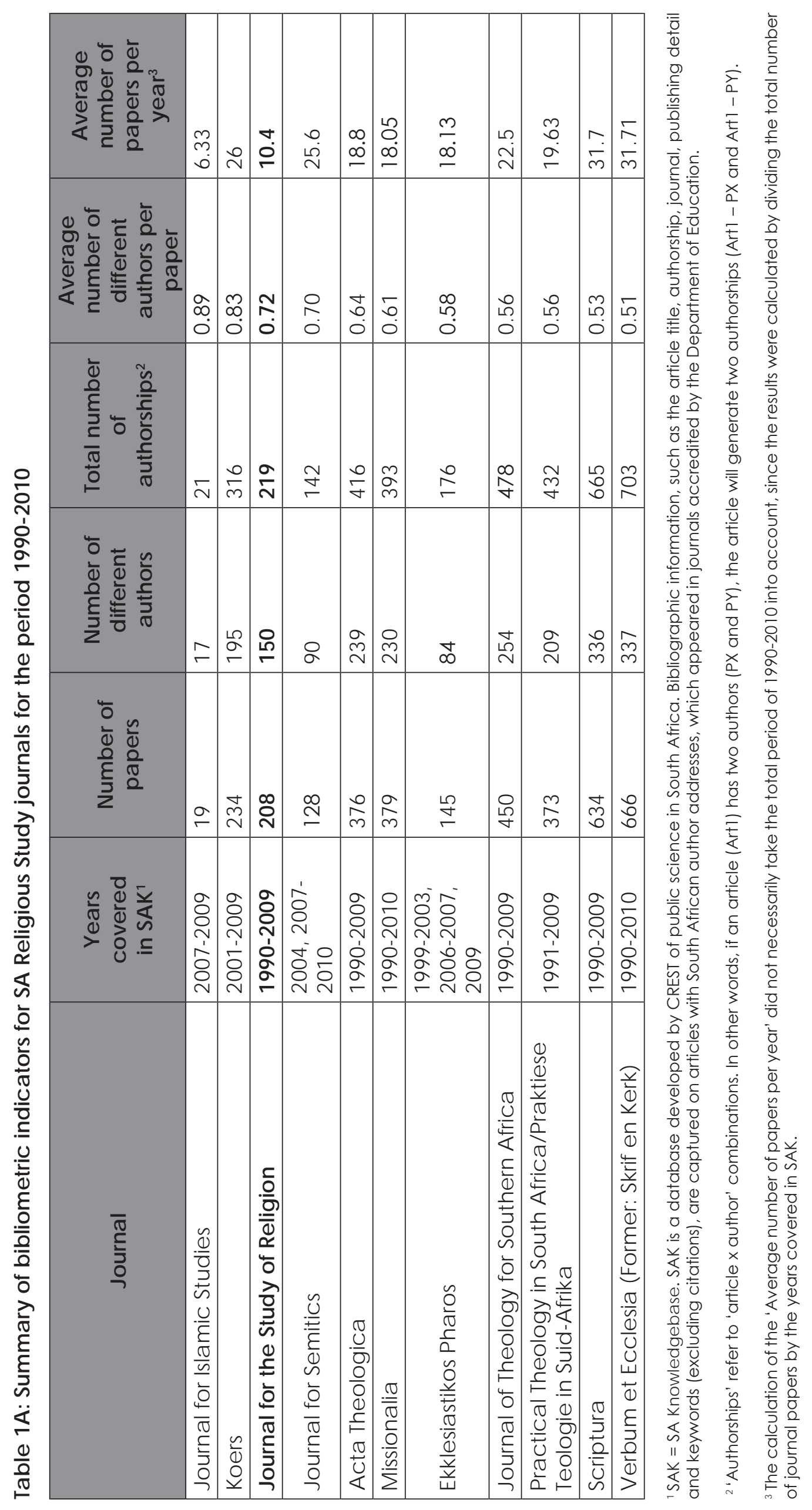




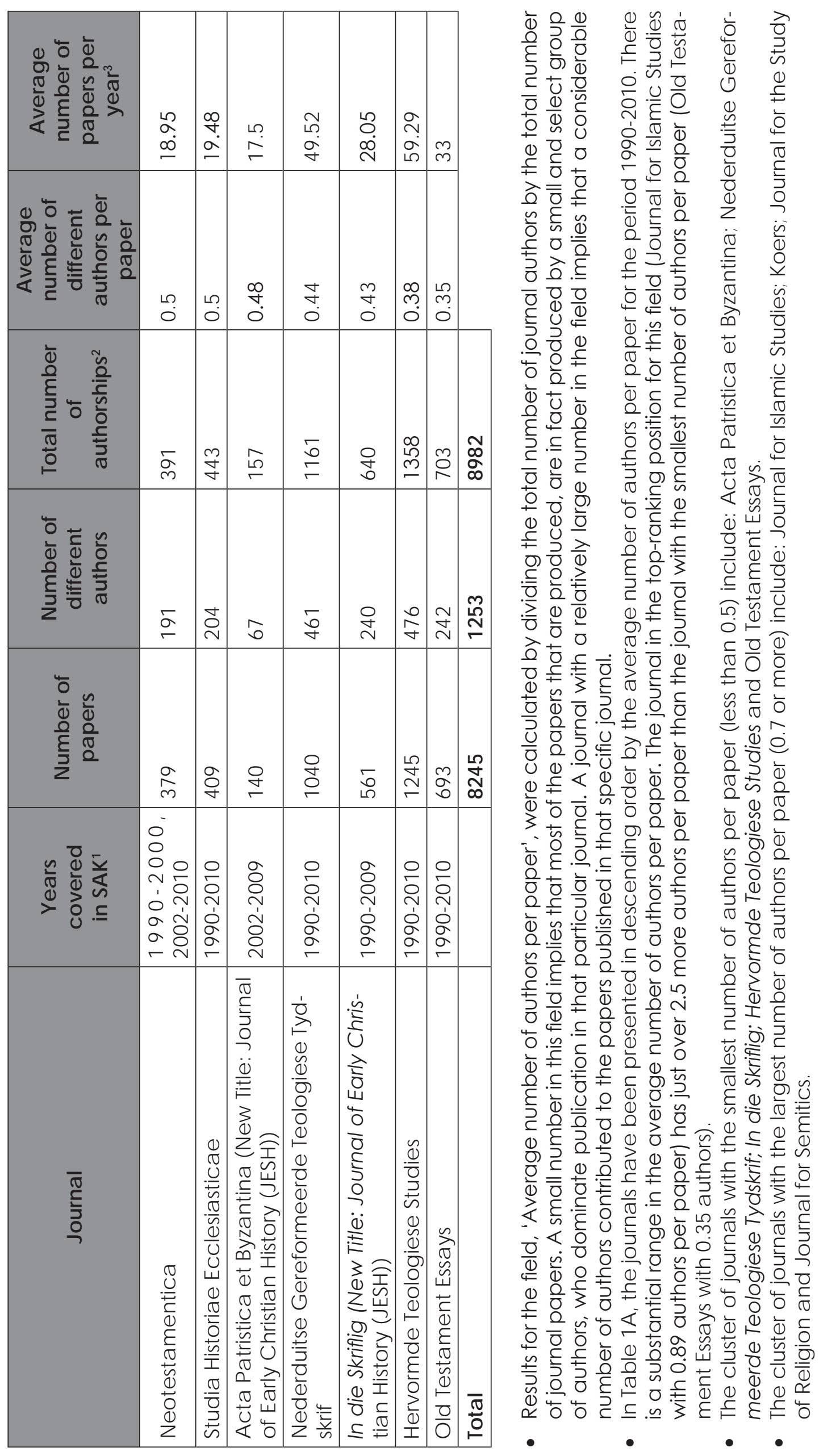




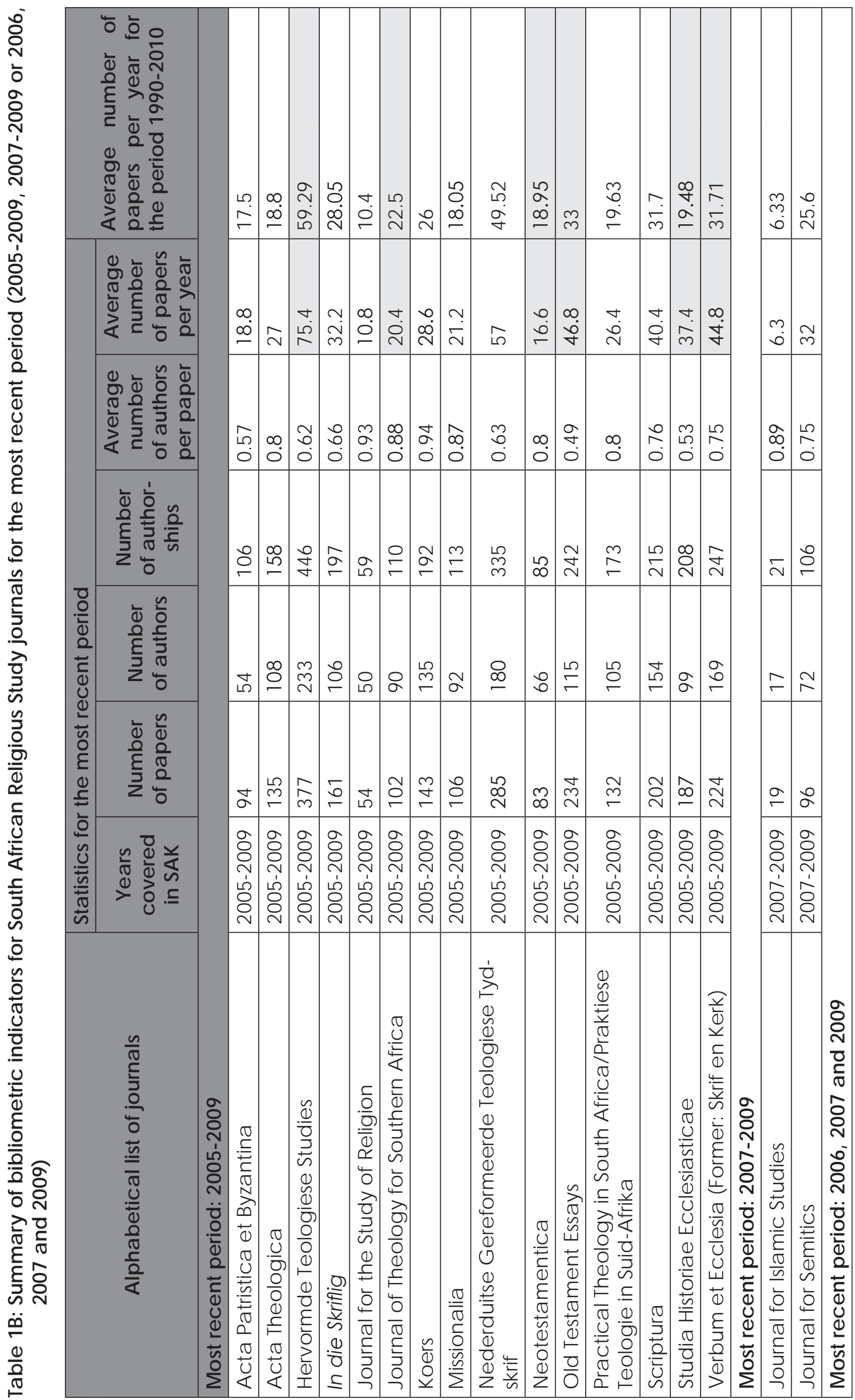




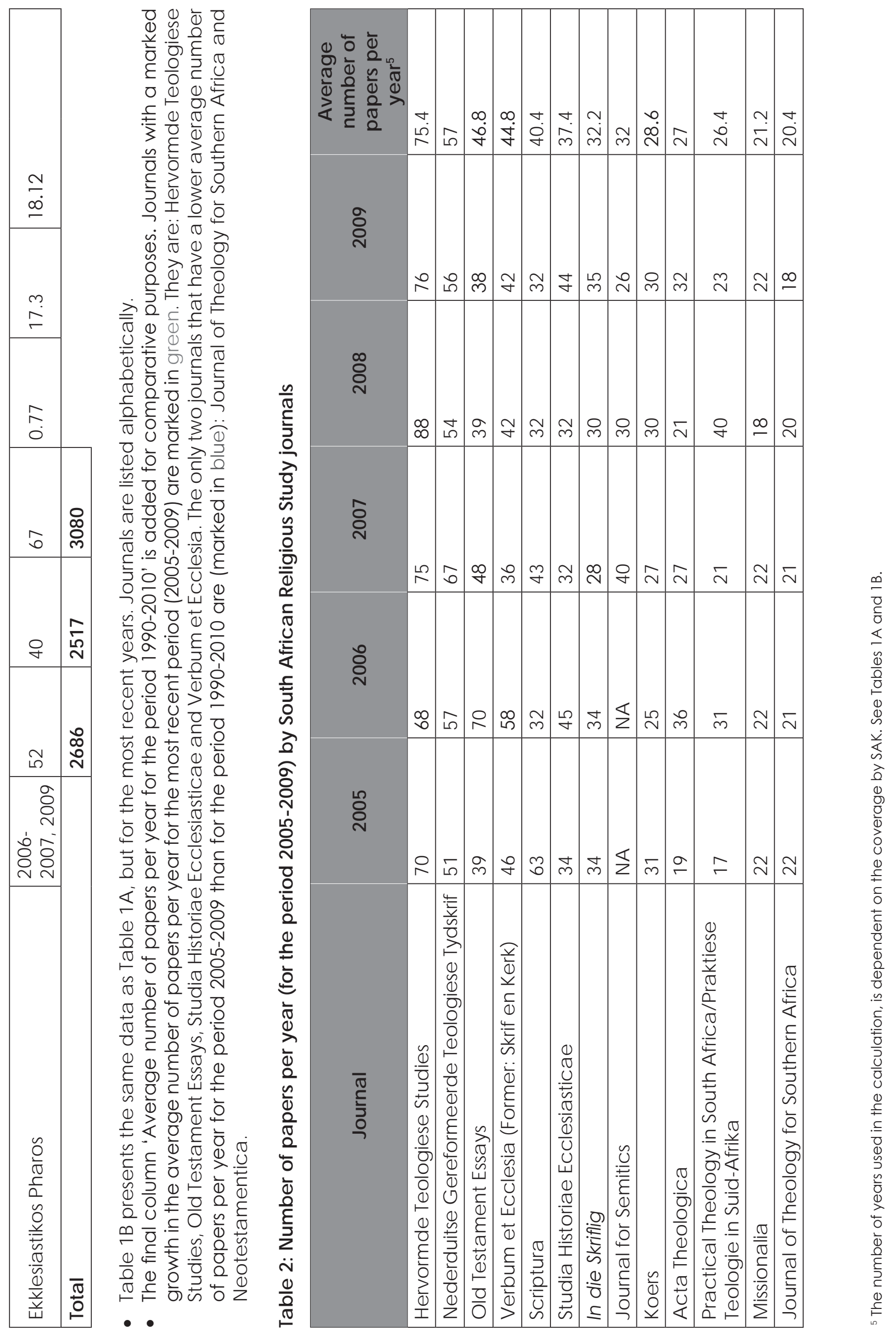




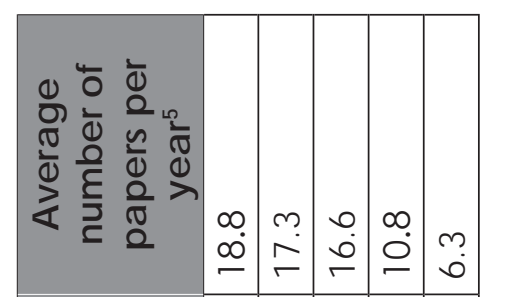

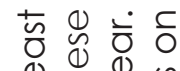

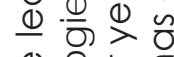

0
0

1 这入

능ㅁㅇ 응 잉

흥응

$\tau \geq \geq 0 \overline{0}$

용

等

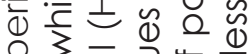

$\therefore 3 \div)^{\circ}$

$\Phi$ 늠

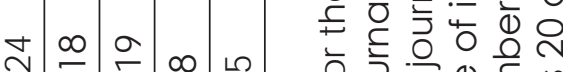

은 으응 है 등

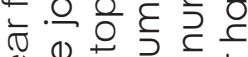

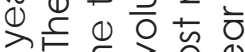

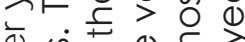

응

ర్

고늠운ㅇ

ఫ్సి

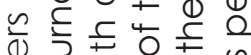

으의

중

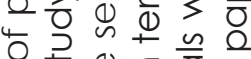

운해은

बू

트으 드으응

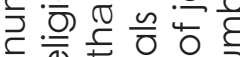

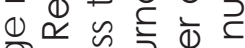

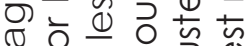
$\frac{0}{9}$

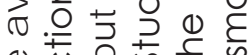

ర్స

\&

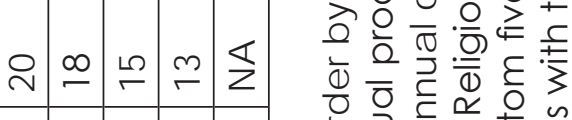

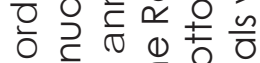

응 두용

등 0 o 0 \&

व

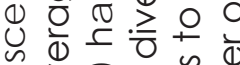

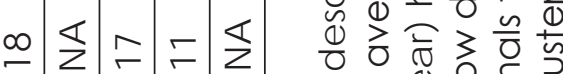

工 $\stackrel{1}{1} 0$

은 응

过 $\subseteq$ व

는

\%

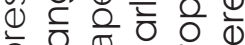

는

으의

$\Phi$

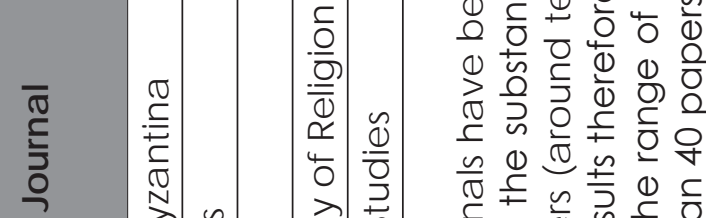

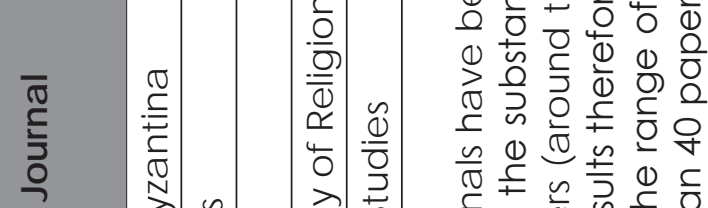

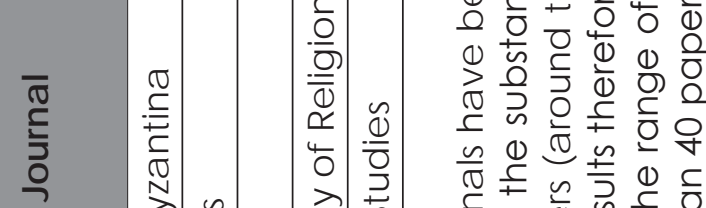

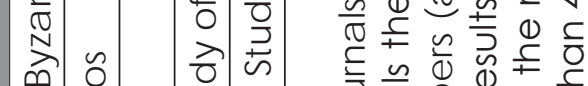

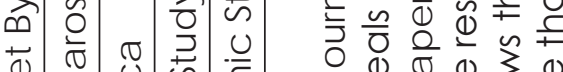

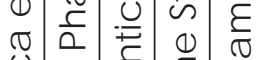

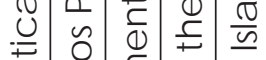

莣

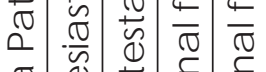

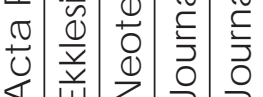

年

宁 는

$\sim \frac{1}{\Omega}$

음 ब可

ॠ

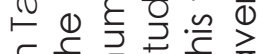

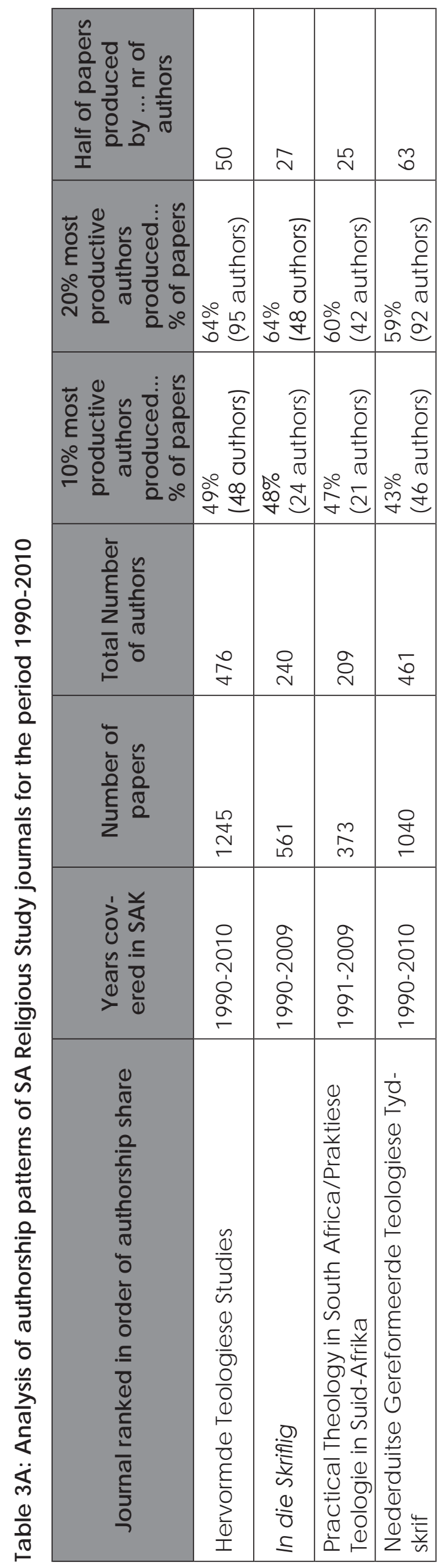




\begin{tabular}{|c|c|c|c|c|c|c|c|c|c|c|c|c|c|}
\hline 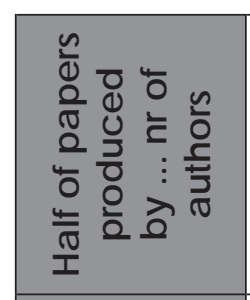 & $\exists$ & in & $\stackrel{\infty}{m}$ & $\stackrel{m}{m}$ & $\vec{F}$ & 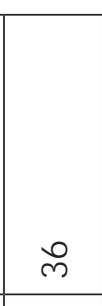 & 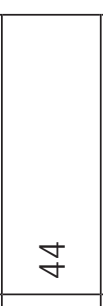 & 6 & $\stackrel{m}{m}$ & $\stackrel{\infty}{+}$ & ถี & m & $\stackrel{\Delta}{N}$ \\
\hline 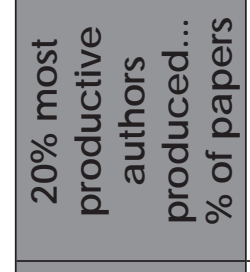 & 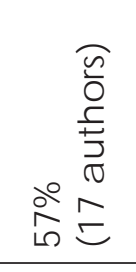 & 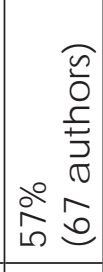 & 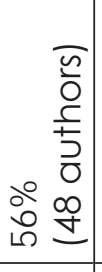 & 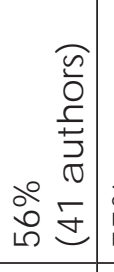 & 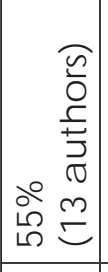 & 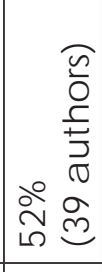 & 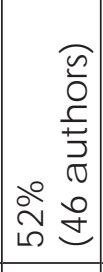 & 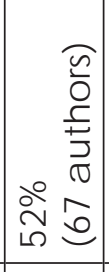 & 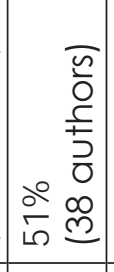 & 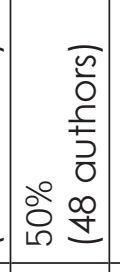 & 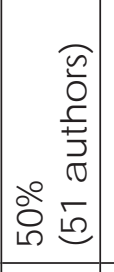 & 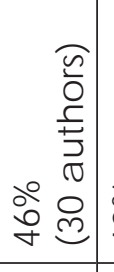 & 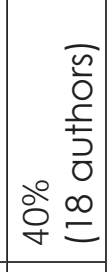 \\
\hline 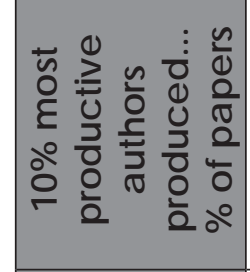 & 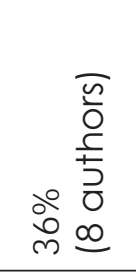 & 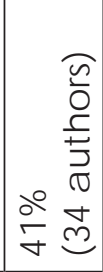 & 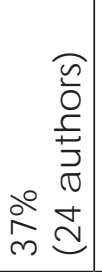 & 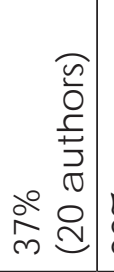 & 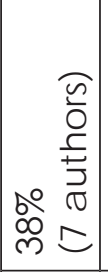 & 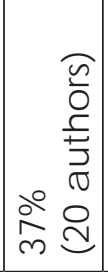 & 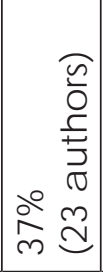 & 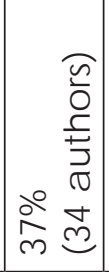 & 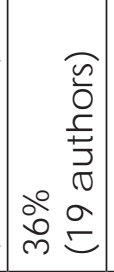 & 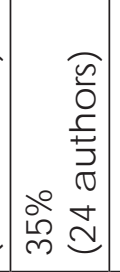 & 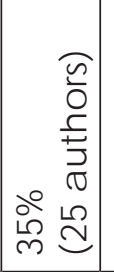 & 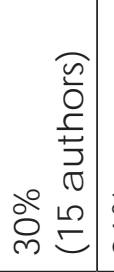 & 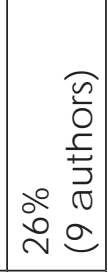 \\
\hline 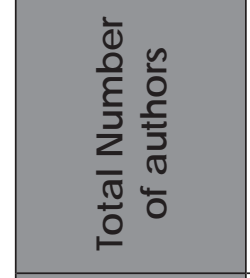 & $\begin{array}{l} \pm \\
\infty\end{array}$ & 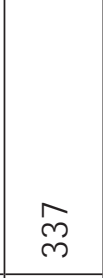 & I & 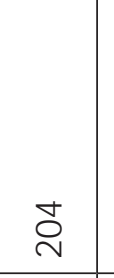 & 6 & $\stackrel{\text { 号 }}{9}$ & $\underset{\sim}{\stackrel{o}{N}}$ & 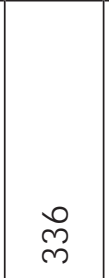 & $\vec{\sigma}$ & $\stackrel{\mathscr{N}}{\sim}$ & 岕 & 㽞 & 8 \\
\hline & $\stackrel{\text { 守 }}{\sim}$ & $\stackrel{\circ}{0}$ & \% & ஓ̊ & g & 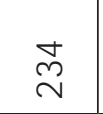 & 令 & 苞 & 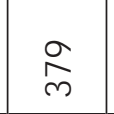 & $\stackrel{0}{m}$ & 号 & $\stackrel{\infty}{\sim}$ & $\stackrel{\infty}{\simeq}$ \\
\hline 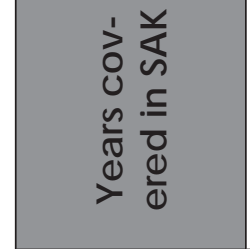 & 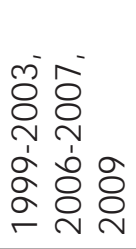 & 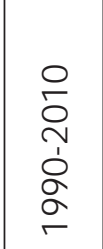 & 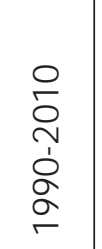 & 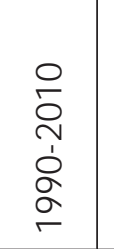 & 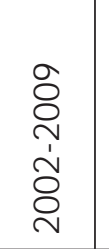 & 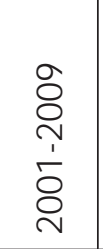 & \begin{tabular}{|l}
0 \\
$\stackrel{0}{1}$ \\
$i$ \\
ò \\
g.
\end{tabular} & 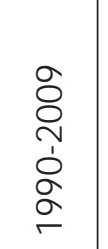 & 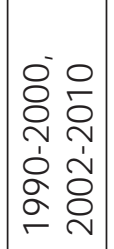 & 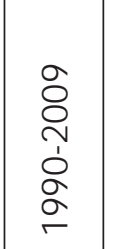 & 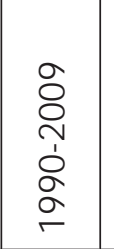 & 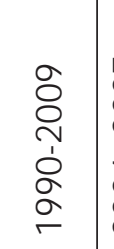 & 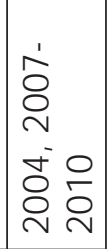 \\
\hline 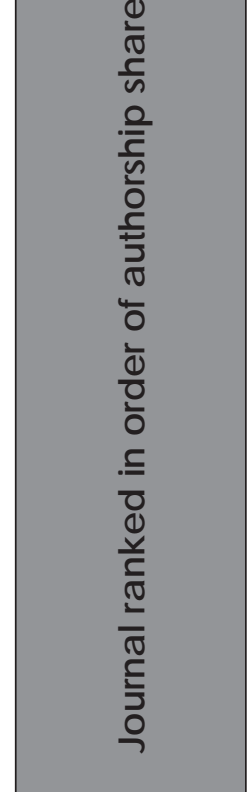 & 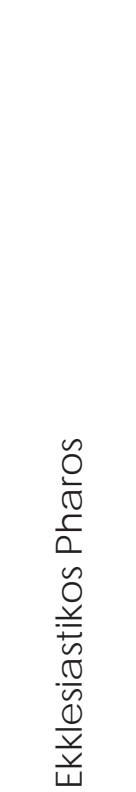 & 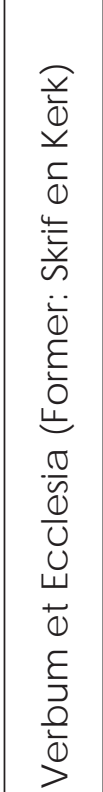 & 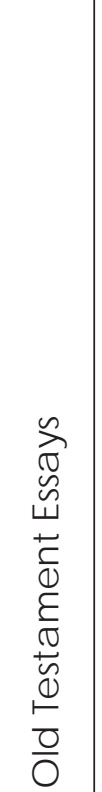 & 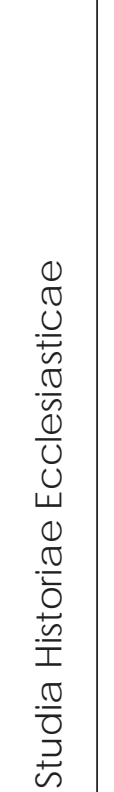 & 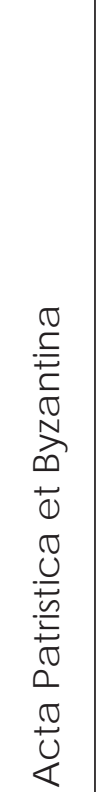 & 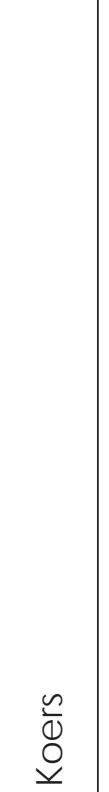 & $\mid$\begin{tabular}{|l|}
$\frac{\underline{0}}{\overline{0}}$ \\
$\frac{0}{0}$ \\
$\frac{0}{60}$ \\
$\frac{6}{\Sigma}$
\end{tabular} & 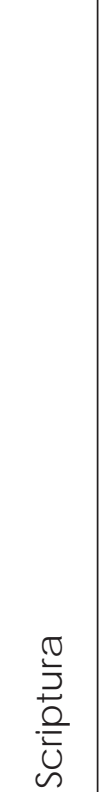 & 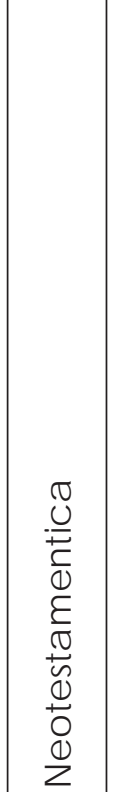 & 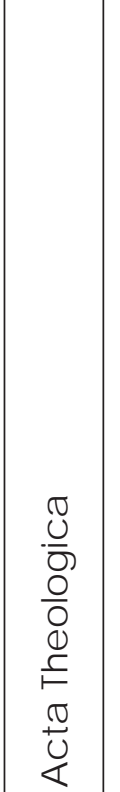 & 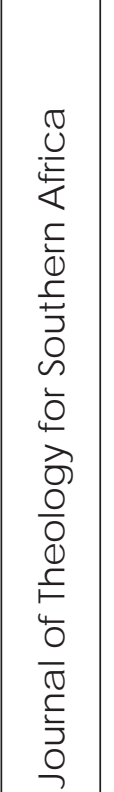 & 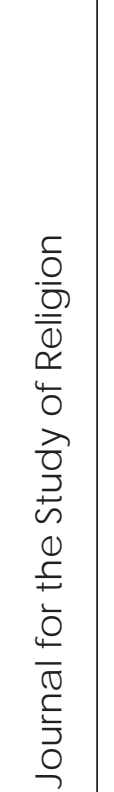 & 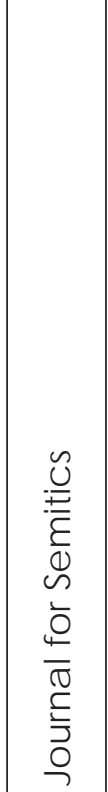 \\
\hline
\end{tabular}




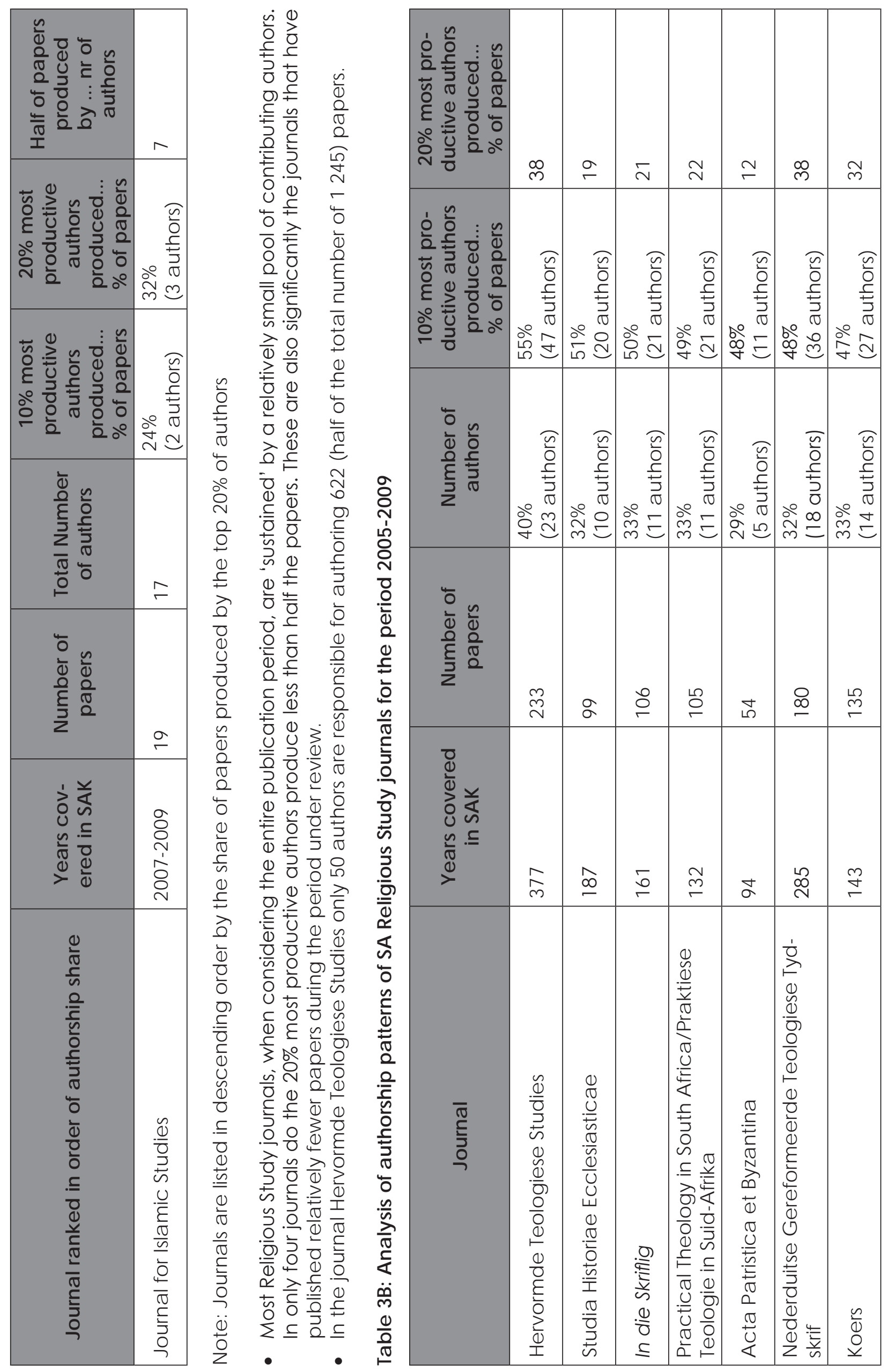




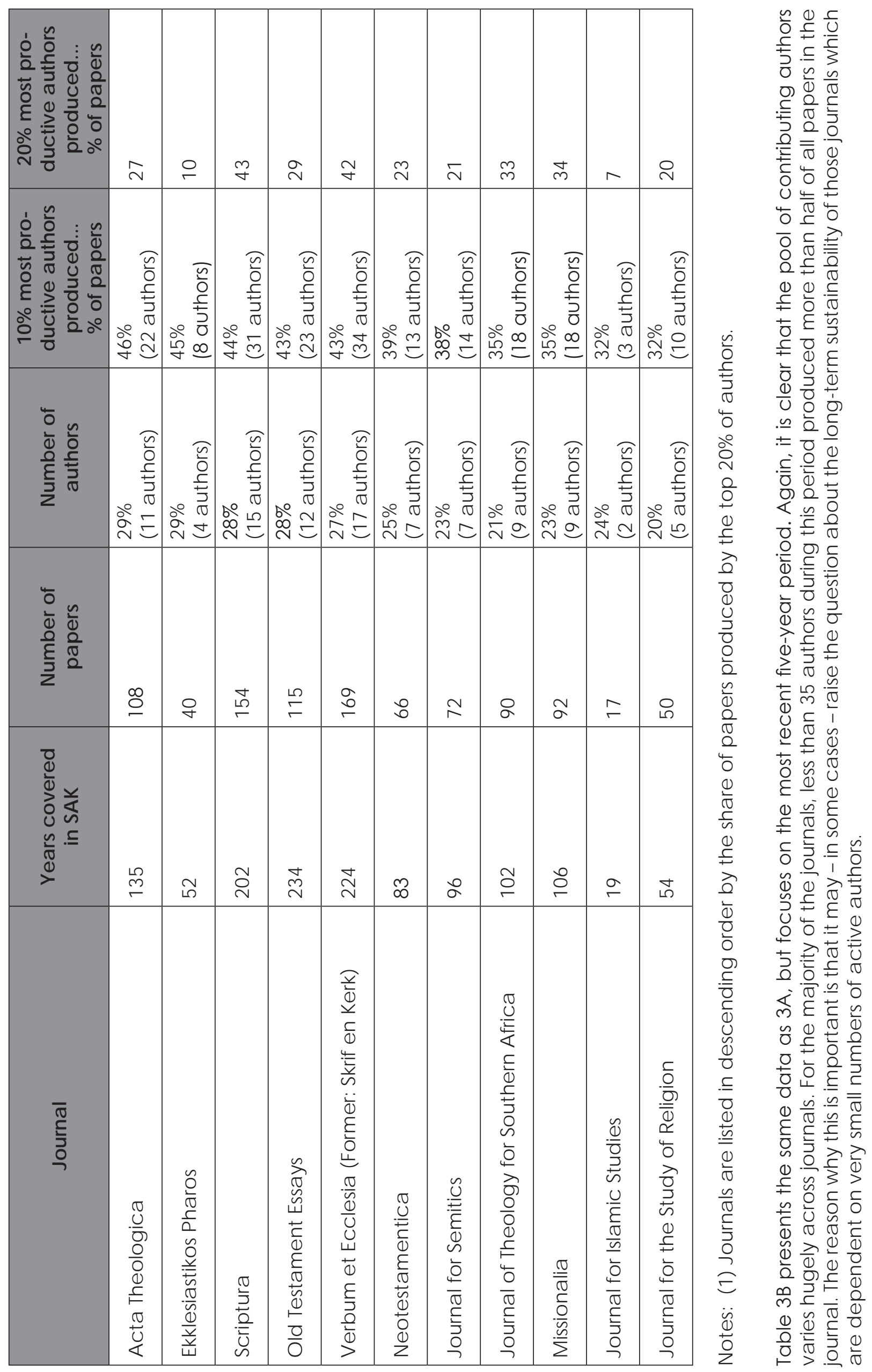




\begin{tabular}{|c|c|c|c|c|c|c|c|c|c|}
\hline 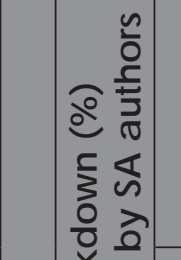 & $\sum_{\xi}^{m}$ & 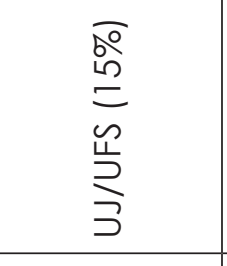 & 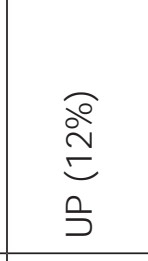 & 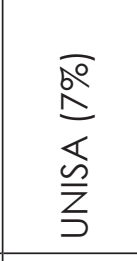 & 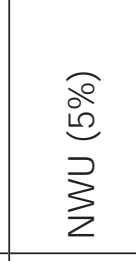 & 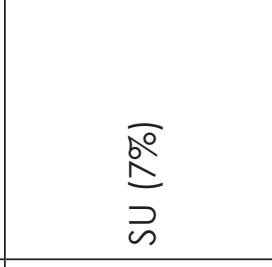 & & 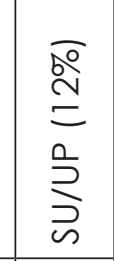 & 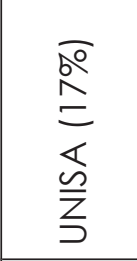 \\
\hline 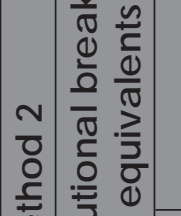 & $\sum_{5}^{N}$ & 参总 & $\begin{array}{l}\overline{50} \\
\stackrel{0}{=} \\
3 \\
0\end{array}$ & 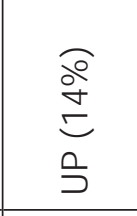 & 寽递 & 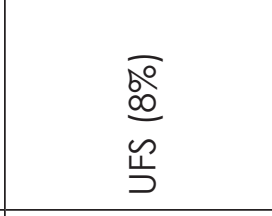 & 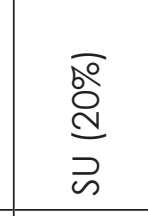 & 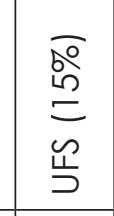 & $\begin{array}{l}\text { 尚 } \\
\text { 学 }\end{array}$ \\
\hline 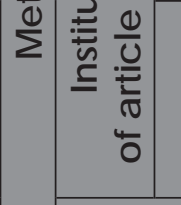 & $\frac{2}{5}$ & $\begin{array}{l}\text { वे } \\
\text { लm } \\
0 \\
0\end{array}$ & 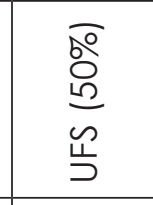 & 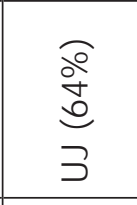 & $\begin{array}{l}\text { ò } \\
\text { ô } \\
0\end{array}$ & 券突 & 它焉递 & 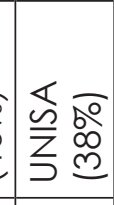 & 氝 \\
\hline 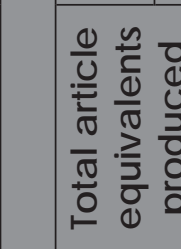 & 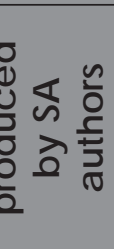 & 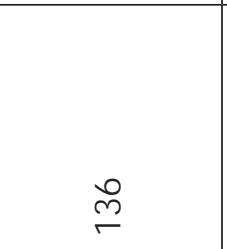 & స్ల్ & 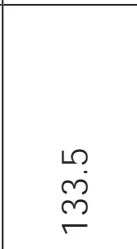 & 总 & $\begin{array}{l}\hat{0} \\
\text { o. } \\
\text { on } \\
\sigma\end{array}$ & n & $\underset{\exists}{\eta}$ & $\approx$ \\
\hline$\frac{\vdots}{\vdots}$ & $\stackrel{m}{?}$ & 玹骂 & 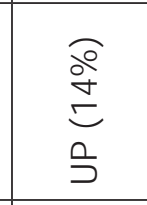 & 竞离。 & 登急 & 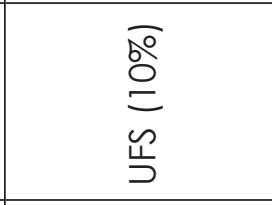 & & $\begin{array}{l}\bar{o} \\
\stackrel{0}{1} \\
\mathrm{~g}\end{array}$ & 壱过 \\
\hline 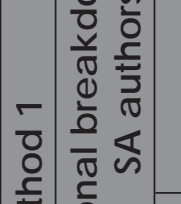 & $\stackrel{2}{z}$ & 岁高 & 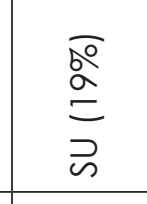 & $\begin{array}{l}\text { ò } \\
\text { do } \\
\frac{0}{3}\end{array}$ & 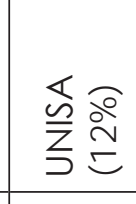 & 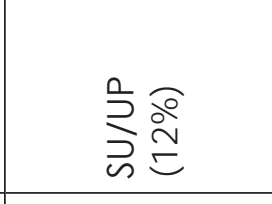 & $\begin{array}{l}\text { Z } \\
\text { 美哭 } \\
\text { 品 }\end{array}$ & 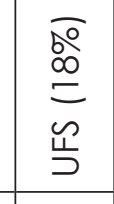 & 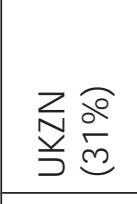 \\
\hline 芒焉 & : & g & 岁鬲 & इ高 & g & 录突 & 包高 & 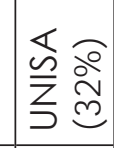 & ঢ) \\
\hline $\begin{array}{l}\frac{5}{4} \\
\frac{0}{2}\end{array}$ & & \& & $\stackrel{\infty}{\infty}$ & $\stackrel{R}{\curvearrowright}$ & 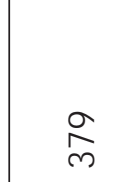 & $\stackrel{\infty}{\infty}$ & $\theta$ & $\hat{\imath}$ & D \\
\hline 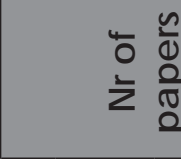 & & $\underset{\sim}{\text { g }}$ & 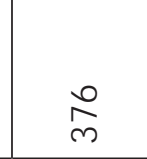 & $\underset{\neg}{\stackrel{\text { f }}{-}}$ & $\stackrel{\text { I }}{\Xi}$ & ర్రి & 9 & $\stackrel{\infty}{\simeq}$ & $\vec{n}$ \\
\hline 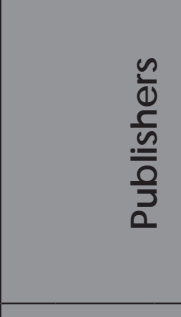 & & 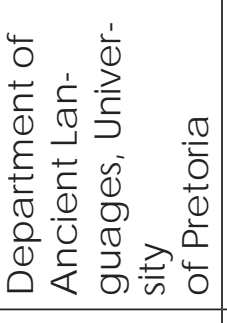 & 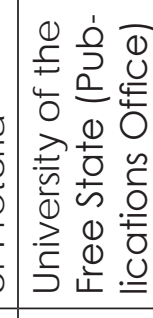 & 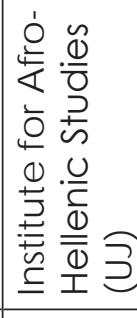 & 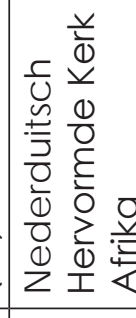 & 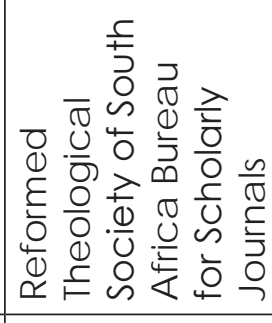 & 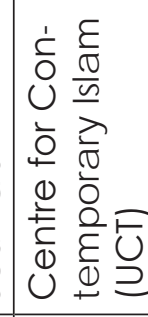 & 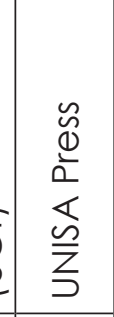 & 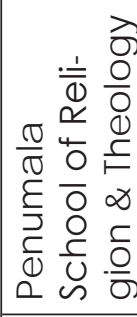 \\
\hline ? & & 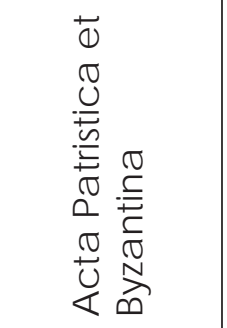 & 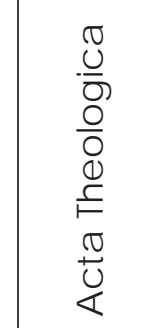 & 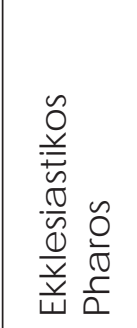 & 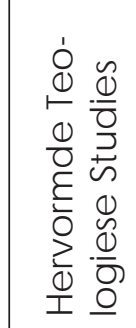 & $\begin{array}{l}\frac{0}{0} \\
\frac{5}{p} \\
\frac{0}{0}\end{array}$ & 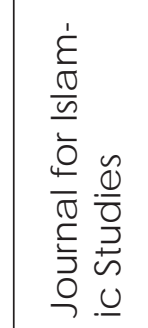 & 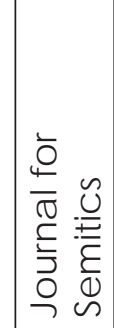 & 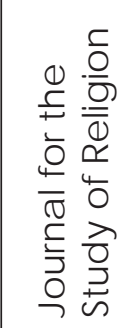 \\
\hline
\end{tabular}




\begin{tabular}{|c|c|c|c|c|c|c|c|c|c|}
\hline 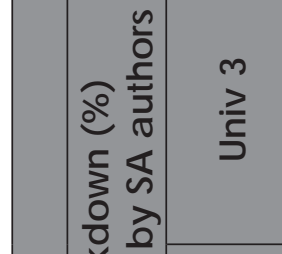 & 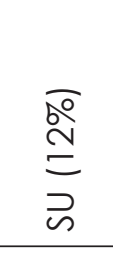 & 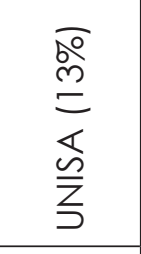 & 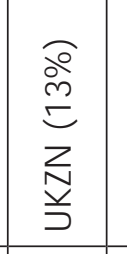 & 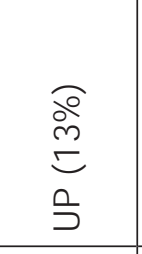 & 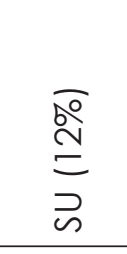 & 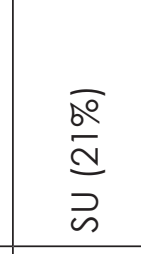 & 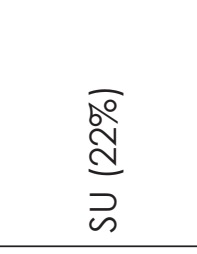 & 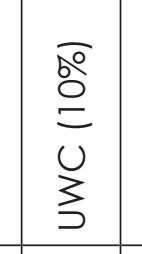 & 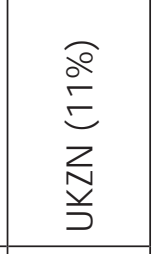 \\
\hline & 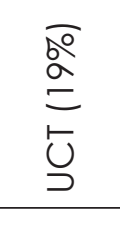 & 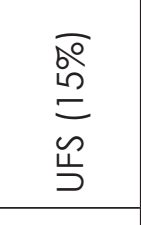 & 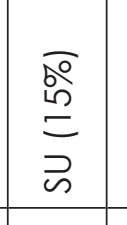 & $\begin{array}{l}\overline{\mathrm{o}} \\
\stackrel{0}{=} \\
\text { 岁 } \\
\end{array}$ & 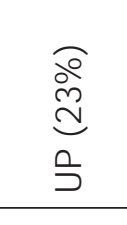 & 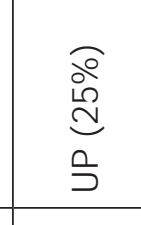 & 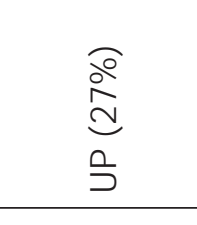 & 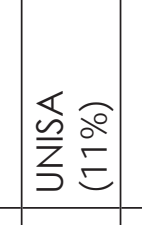 & 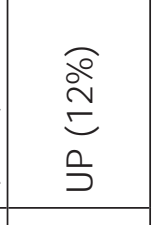 \\
\hline 疍 & 焉高 & 续高 & 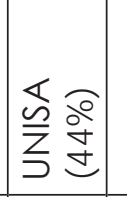 & 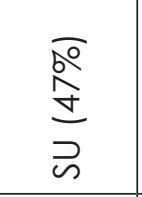 & 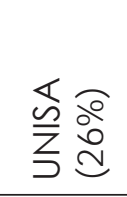 & 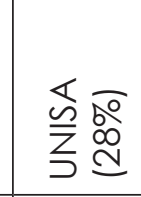 & 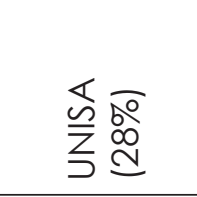 & 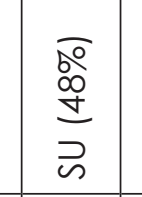 & 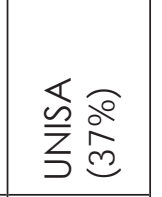 \\
\hline 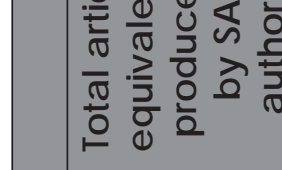 & 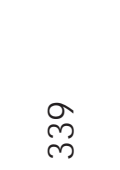 & 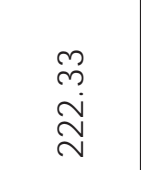 & I & 岕 & 亦 & 吕 & స్ల & ్ָ & $\stackrel{\infty}{\check{j}^{\infty}}$ \\
\hline$\stackrel{m}{2}$ & 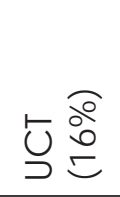 & 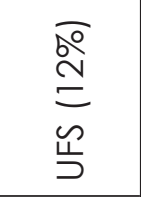 & 㺼 & 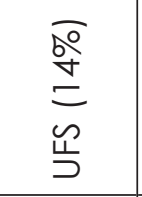 & 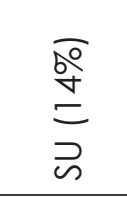 & 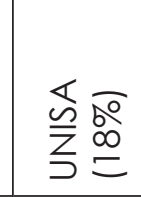 & 票 & 昰递 & 春高 \\
\hline 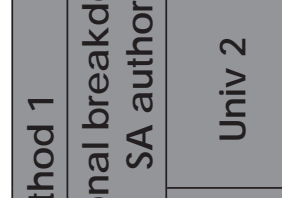 & 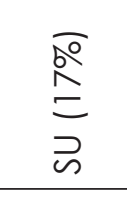 & 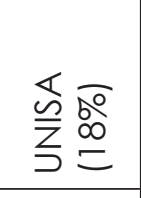 & 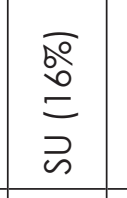 & 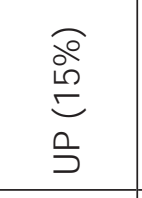 & 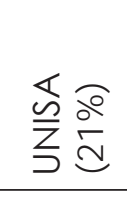 & 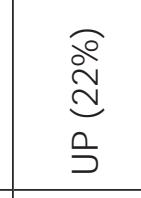 & 离彥 & 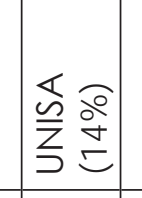 & 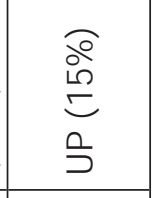 \\
\hline 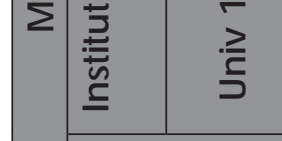 & 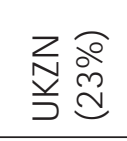 & 良兽 & | & 沯 & g & ๘ & $\mathrm{s}$ & ๘ & 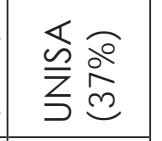 \\
\hline 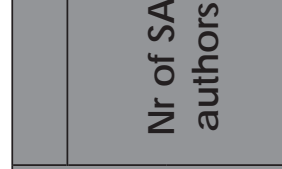 & $\stackrel{\varrho}{~}$ & $\stackrel{\leftrightarrow}{\varrho}$ & $\stackrel{\tilde{q}}{\sim}$ & $\underset{m}{\Delta}$ & $\stackrel{\infty}{=}$ & $\stackrel{\varrho}{\varrho}$ & 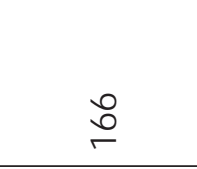 & Iี & $\stackrel{\infty}{\underline{+}}$ \\
\hline 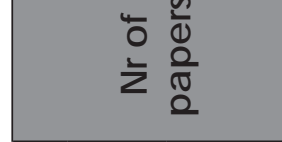 & 㝵 & 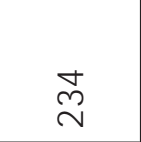 & 临 & 号 & I & 茴 & 吕 & 范 & ఫ্ \\
\hline 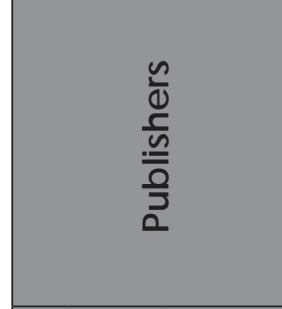 & 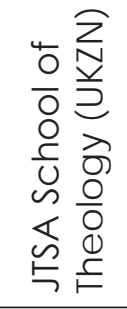 & 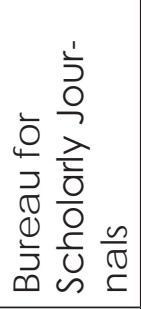 & 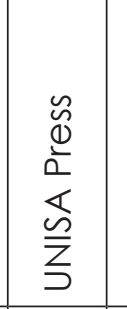 & 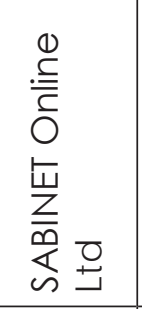 & 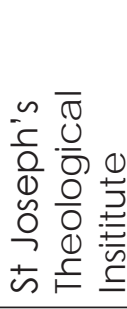 & 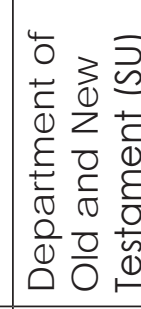 & 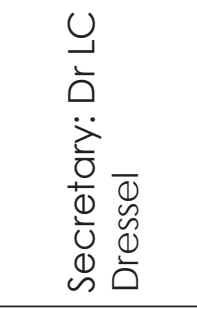 & $\mid$ & 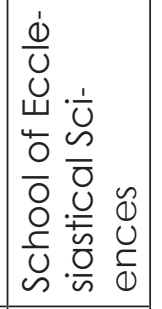 \\
\hline 舀 & 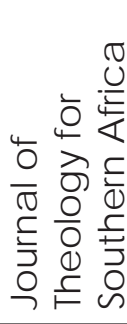 & 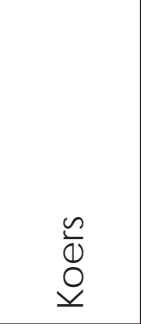 & 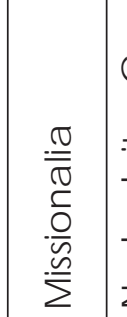 & 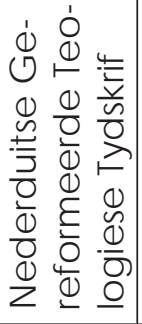 & 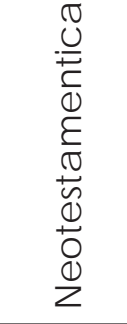 & 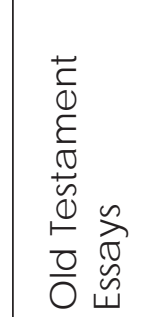 & 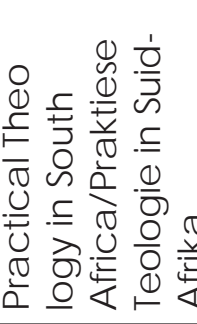 & 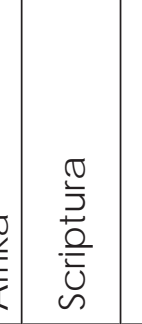 & 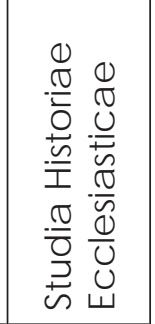 \\
\hline
\end{tabular}




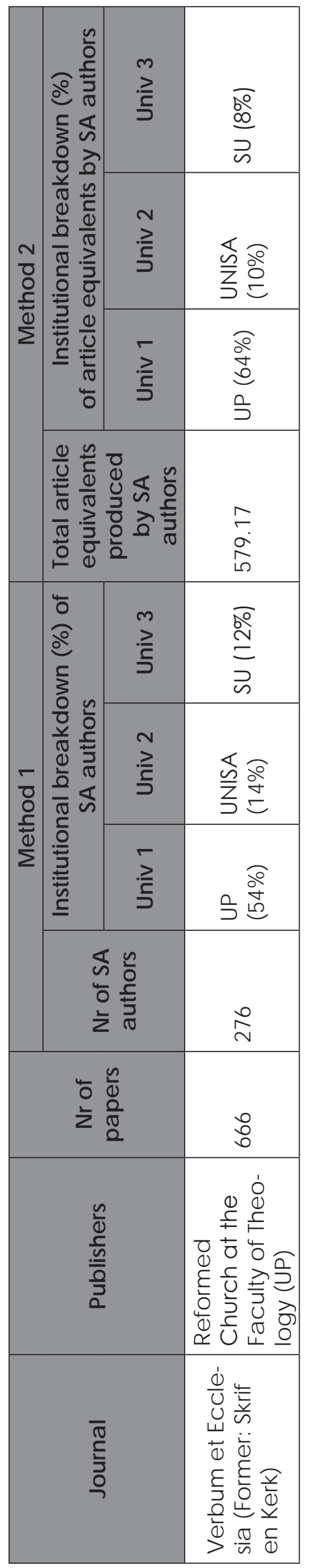

인

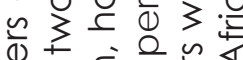

U⿺辶寸

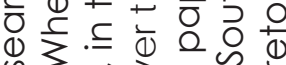

ब出

(1) $\frac{1}{2}-4$

ब

岳

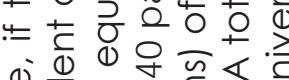

(i) $\frac{0}{0} \stackrel{+}{\bar{C}} \ll$

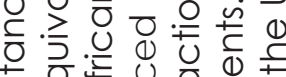

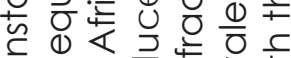

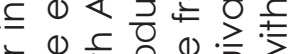

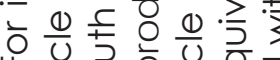

i)

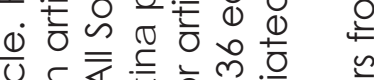

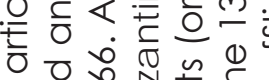

ᄃ

吅

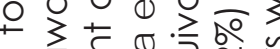

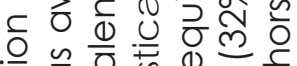

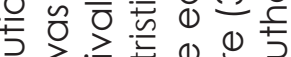

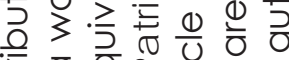

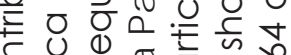

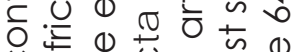

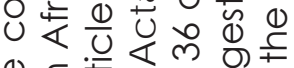

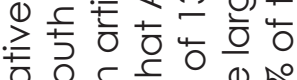

元

幺

高

站记

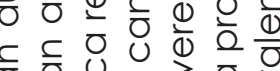

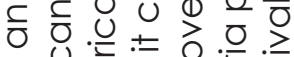

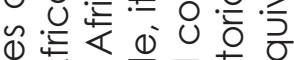

岁先

बᄃ节 $\varepsilon$ 응 0

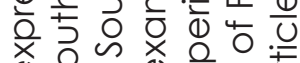

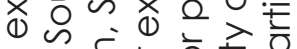

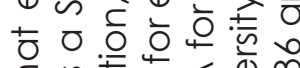

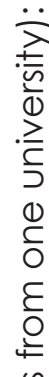

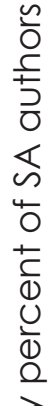

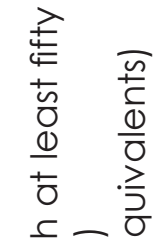

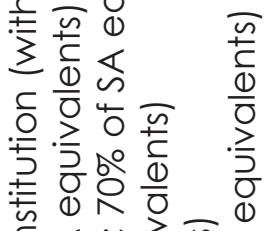

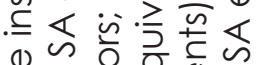

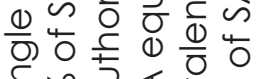

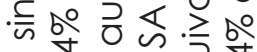

0 近

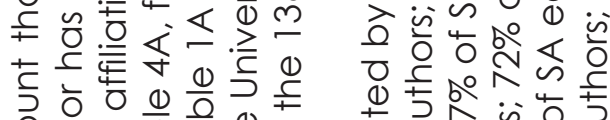

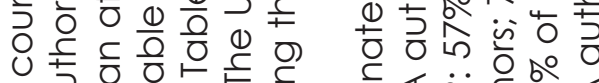

证讨

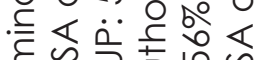

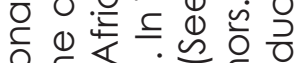

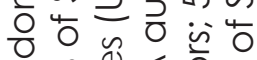

产

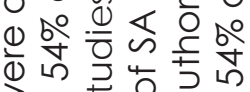

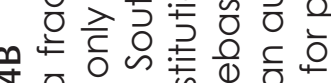

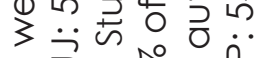

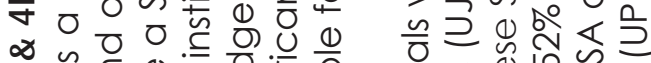

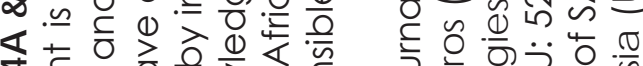

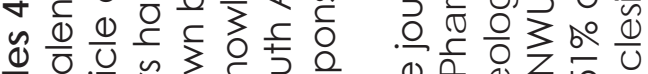

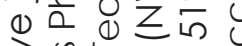

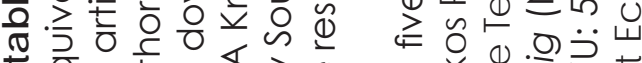

.당

(1) ठ

.

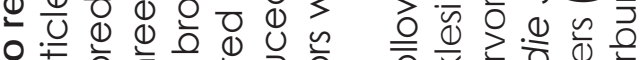

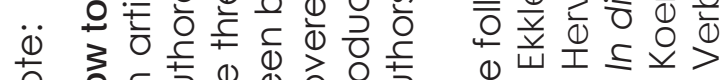

$\stackrel{x}{\frac{\pi}{2}} \frac{0}{2}$

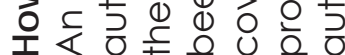

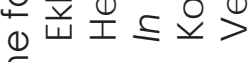




\begin{tabular}{|c|c|c|c|c|c|c|c|c|}
\hline 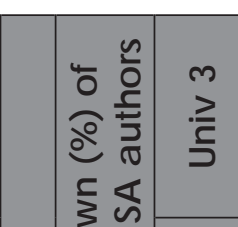 & 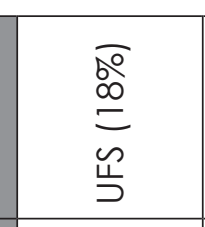 & 勇拿 & 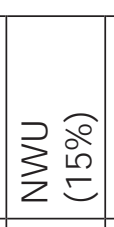 & 递 & 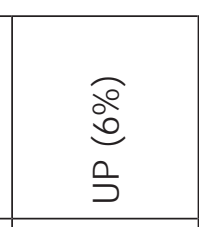 & & 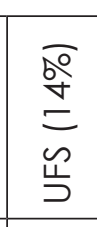 & 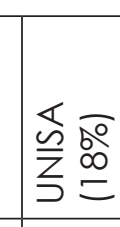 \\
\hline 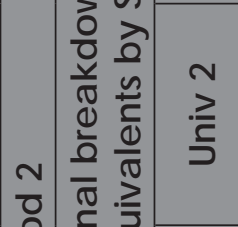 & 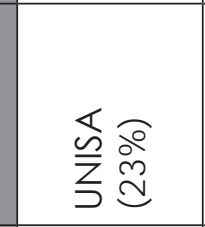 & 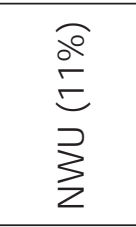 & $\begin{array}{l}10 \\
0 \\
0 \\
0 \\
0 \\
0\end{array}$ & 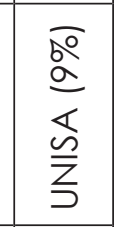 & 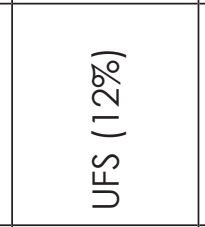 & 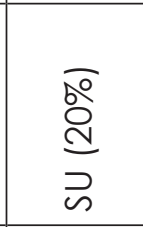 & 羙总 & 㕅 \\
\hline 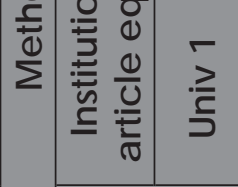 & 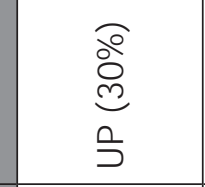 & 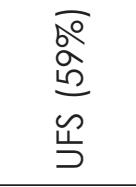 & 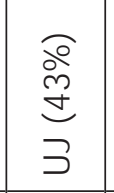 & 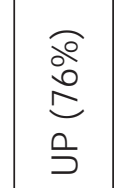 & 娄总 & 它要良 & 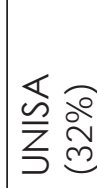 & \begin{tabular}{lll} 
\\
\hdashline
\end{tabular} \\
\hline 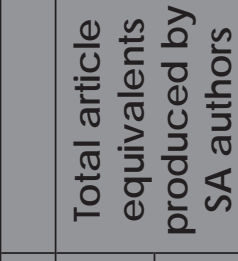 & $\begin{array}{l}8 \\
\text { ì }\end{array}$ & 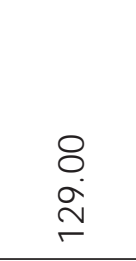 & $\begin{array}{l}8 \\
\dot{g} \\
\dot{q}\end{array}$ & 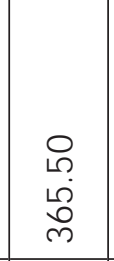 & 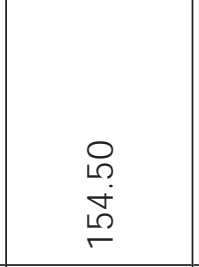 & $\underset{\text { in }}{8}$ & $\begin{array}{l}8 \\
\\
\end{array}$ & 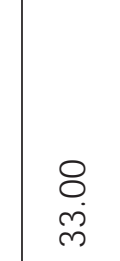 \\
\hline 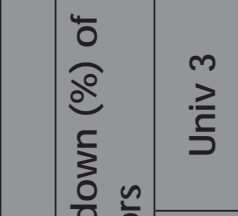 & 登咅 & $\begin{array}{l}\text { à } \\
\stackrel{a}{d} \\
\text { a }\end{array}$ & 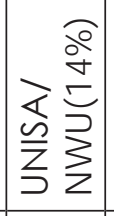 & 鸪 & 总 & & 岁。 & 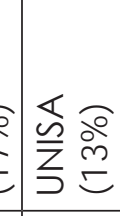 \\
\hline 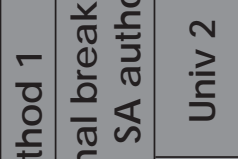 & 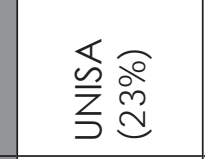 & 沗 & ร) & 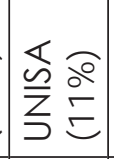 & 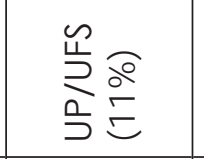 & 要高 & $9 \stackrel{\circ}{g}$ & 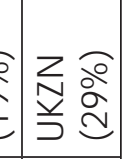 \\
\hline 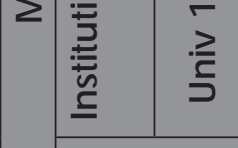 & s & 岁总通 & ऽ高 & 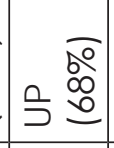 & 胥䒽 & 包高 & 范望 & 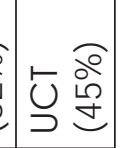 \\
\hline 总范 & ก & ऽ̊ & $\stackrel{\sim m}{m}$ & $\tilde{\mathbb{N}}$ & $\vec{g}$ & $\sigma$ & ภ̊ & \\
\hline 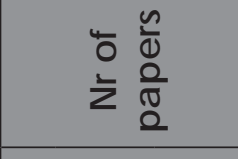 & बे & 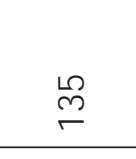 & กิ & $\stackrel{\hat{m}}{m}$ & $\overrightarrow{\vec{\sigma}}$ & 9 & 8 & 号 \\
\hline 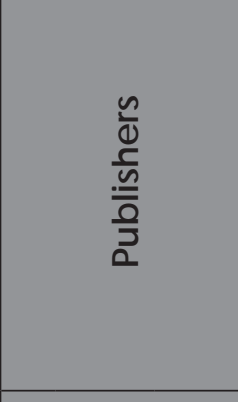 & 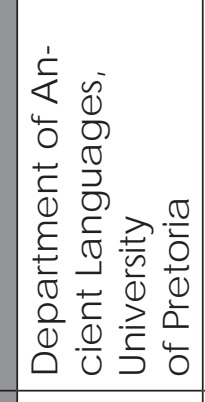 & 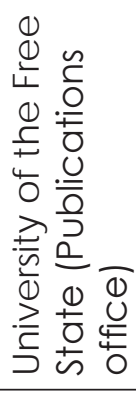 & 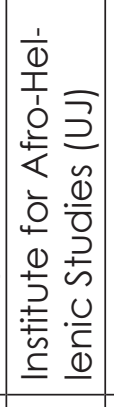 & 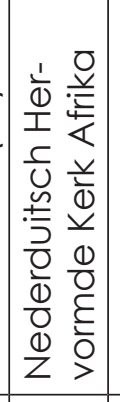 & 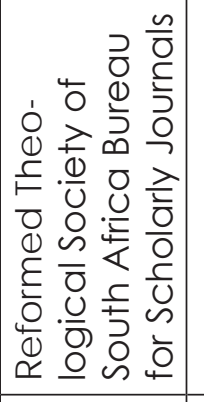 & 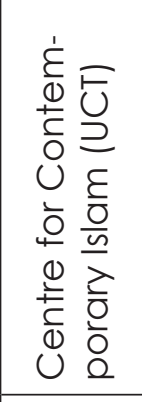 & 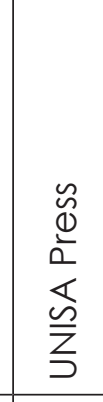 & 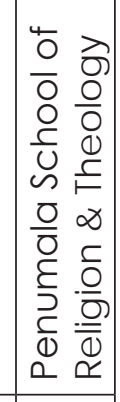 \\
\hline$\underline{E}$ & 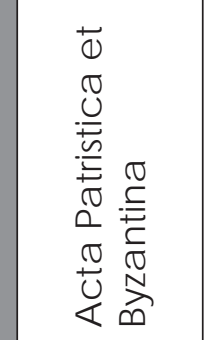 & 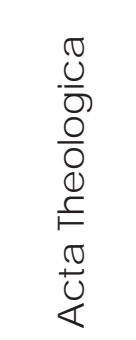 & 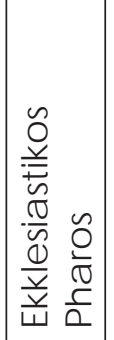 & 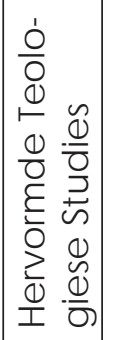 & 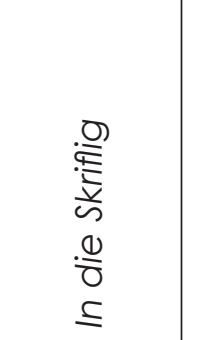 & 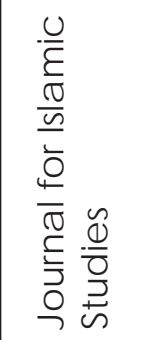 & 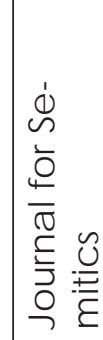 & 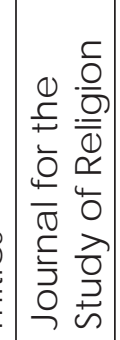 \\
\hline
\end{tabular}




\begin{tabular}{|c|c|c|c|c|c|c|c|c|c|}
\hline 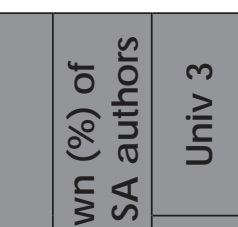 & $\begin{array}{l}\frac{50}{\stackrel{5}{E}} \\
\stackrel{5}{5} \\
\text { J }\end{array}$ & 芯 & 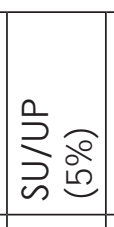 & 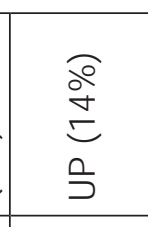 & $\begin{array}{l}\stackrel{\overline{0}}{\stackrel{0}{O}} \\
\stackrel{5}{5}\end{array}$ & 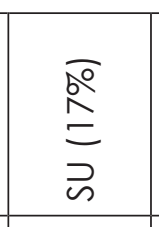 & $\begin{array}{l}\text { 美令 } \\
\text { 点 }\end{array}$ & है & \\
\hline 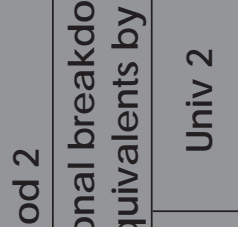 & 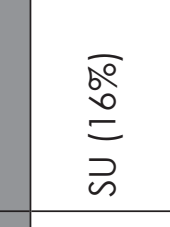 & $\begin{array}{l}\text { 足 } \\
\stackrel{0}{=} \\
\stackrel{4}{y} \\
\end{array}$ & 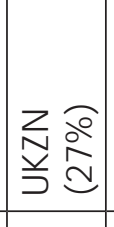 & $\begin{array}{l}\text { 吕 } \\
\stackrel{a}{=} \\
\text { 岁 } \\
\end{array}$ & 㝋递 & $\begin{array}{l}\sqrt{0} \\
\stackrel{0}{0} \\
\stackrel{N}{3} \\
0\end{array}$ & $\begin{array}{l}\text { 㝵 } \\
\stackrel{0}{1} \\
0\end{array}$ & & \\
\hline 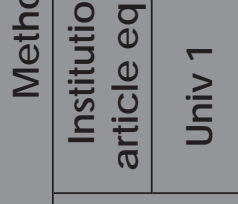 & 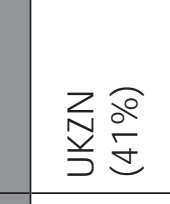 & 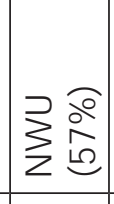 & 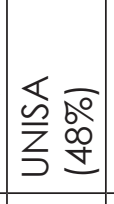 & $\begin{array}{l}\frac{\sqrt{0}}{\tilde{d}^{2}} \\
\frac{2}{2} \\
\end{array}$ & $\begin{array}{l}\text { वें } \\
\text { g̀ } \\
\text { g }\end{array}$ & 产高 & 离离 & 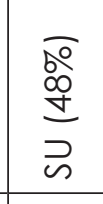 & 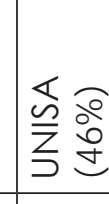 \\
\hline 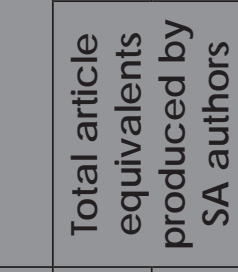 & $\begin{array}{l}n \\
5 \\
5 \\
5 \\
5 \\
5 \\
\end{array}$ & 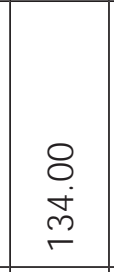 & $\begin{array}{l}8 \\
\text { চ़े } \\
\end{array}$ & 肙 & $\begin{array}{l}8 \\
\dot{1} \\
6 \\
\end{array}$ & $\begin{array}{l}8 \\
\text { ì } \\
\text { in }\end{array}$ & 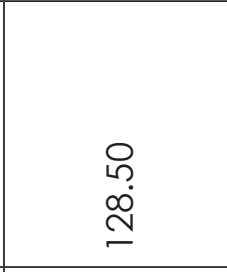 & $\begin{array}{l}8 \\
0 \\
\\
\end{array}$ & 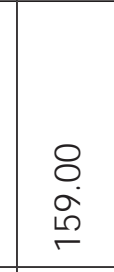 \\
\hline 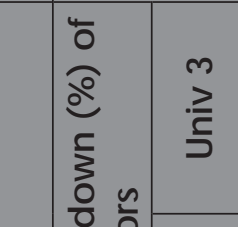 & 产高 & 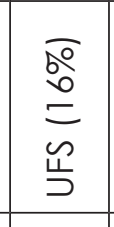 & 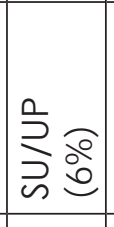 & $\begin{array}{l}\frac{\sqrt{0}}{\stackrel{5}{5}} \\
\text { 岁 }\end{array}$ & 芯哭 & $\stackrel{\substack{\overline{0} \\
ٍ}}{5}$ & 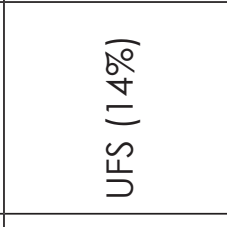 & & 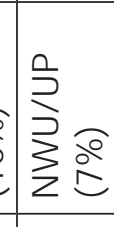 \\
\hline 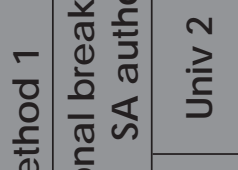 & $\lesssim \stackrel{\substack{\circ \\
\infty}}{=}$ & 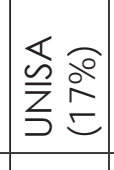 & 尚 & $\mathrm{S} \stackrel{\substack{\overline{0} \\
\infty}}{=}$ & 函 & 舀递 & s & & \\
\hline 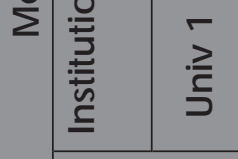 & 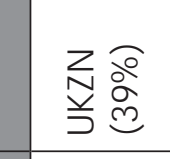 & 品 & $\mid$ & 官 & s & 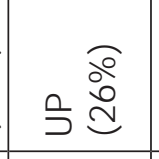 & 䓅高 & 的 & \\
\hline $2 \pi$ & 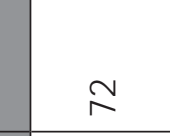 & 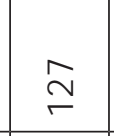 & กิ & 太 & 8 & a & $\vec{a}$ & $\exists$ & $\bar{\infty}$ \\
\hline 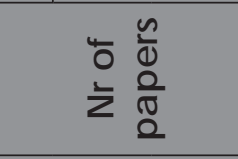 & ک్త్ & $\stackrel{m}{+}$ & $\stackrel{8}{\circ}$ & $\begin{array}{l}\infty \\
\sim \\
\sim\end{array}$ & $\infty$ & 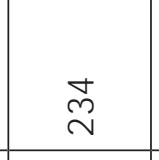 & $\tilde{\tilde{m}}$ & กิ & $\underline{\underline{0}}$ \\
\hline$\frac{\frac{0}{2}}{\frac{\underline{\underline{m}}}{\overline{2}}}$ & 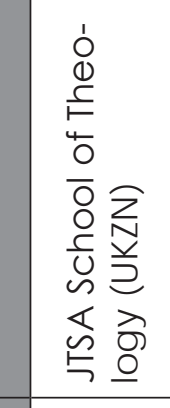 & 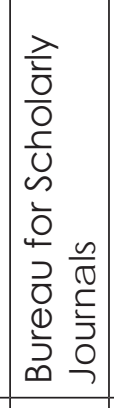 & 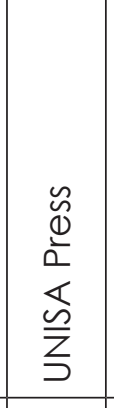 & 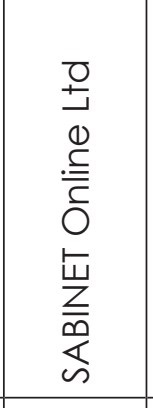 & 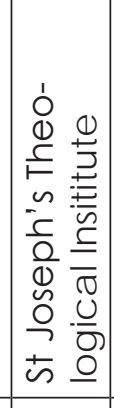 & 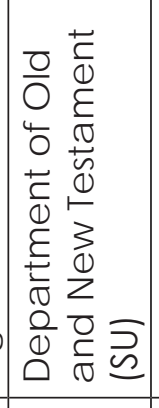 & 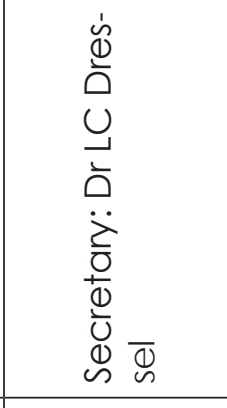 & 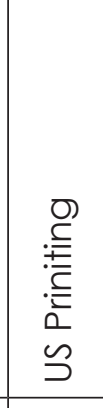 & 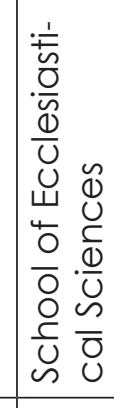 \\
\hline है & 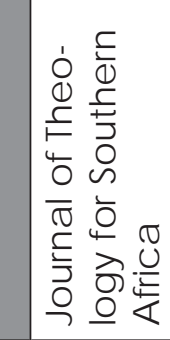 & $\bar{\sigma}$ & 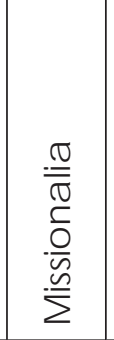 & 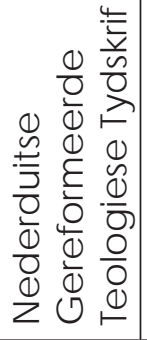 & 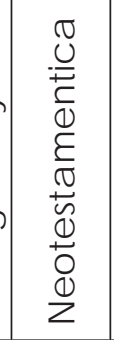 & 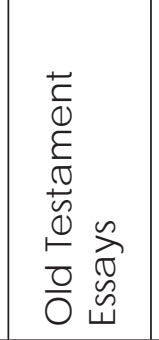 & 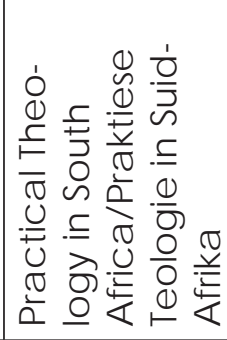 & 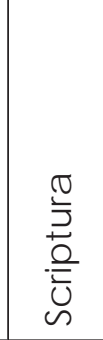 & 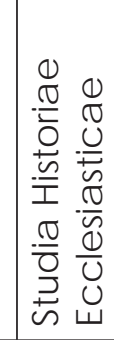 \\
\hline
\end{tabular}




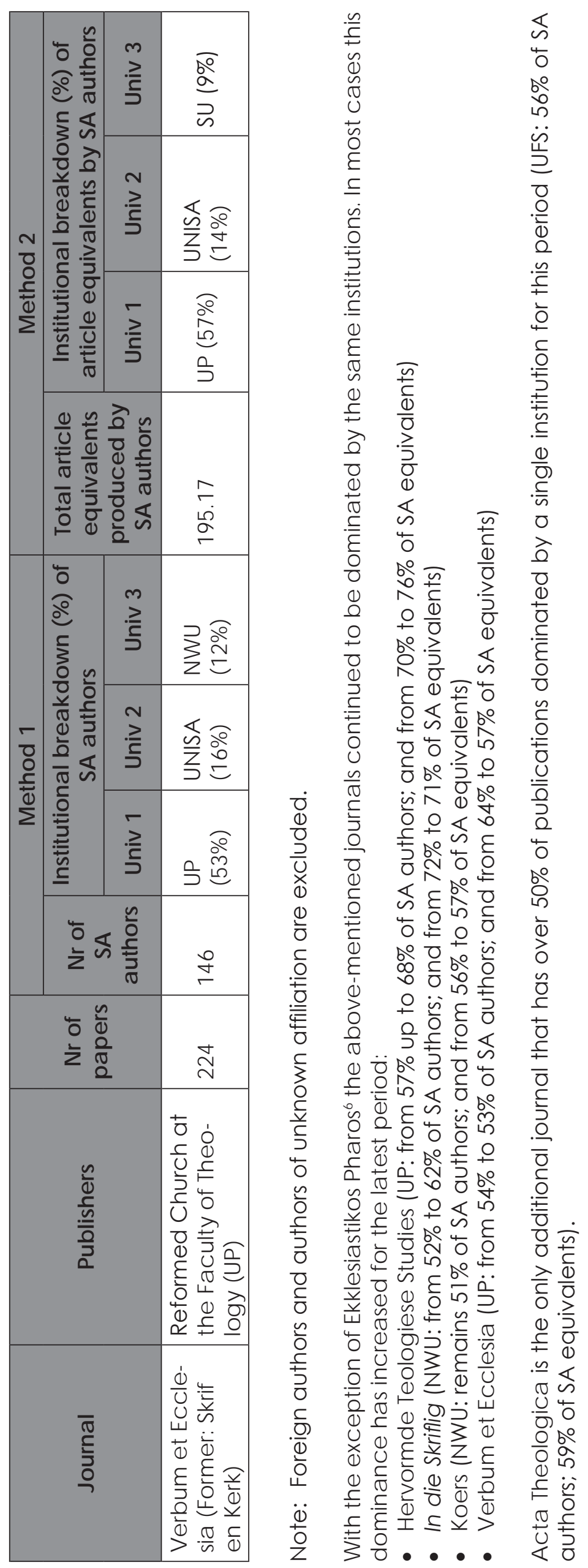




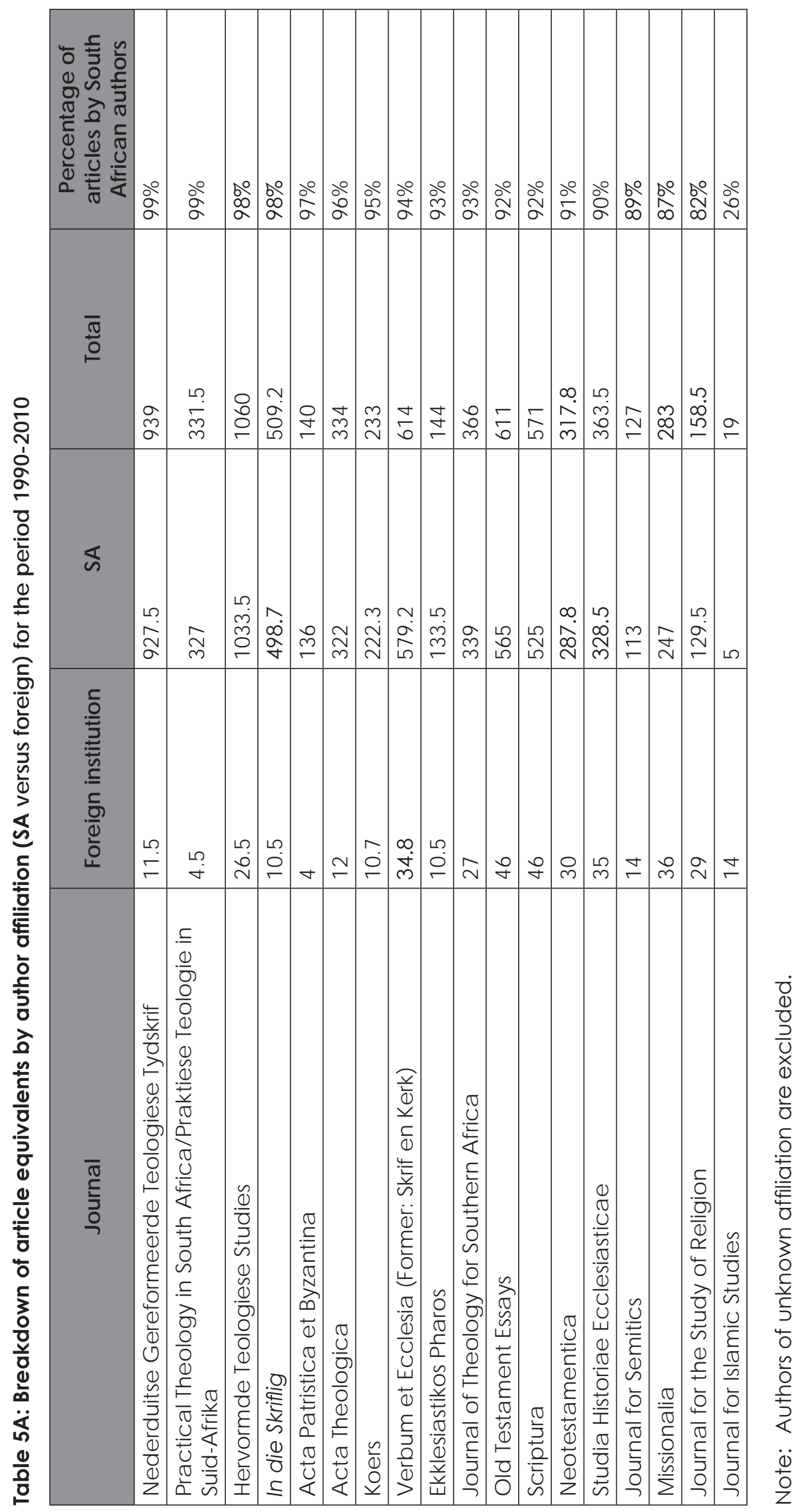




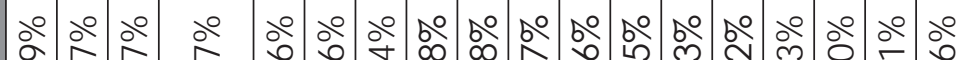
ஃর人

웅

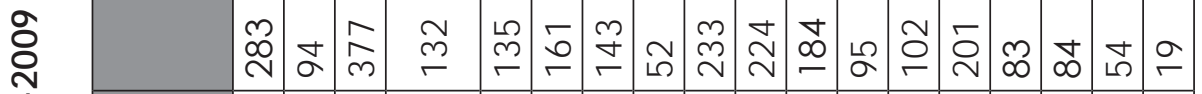

崖

.

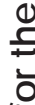

$\frac{\sqrt{2}}{2}$

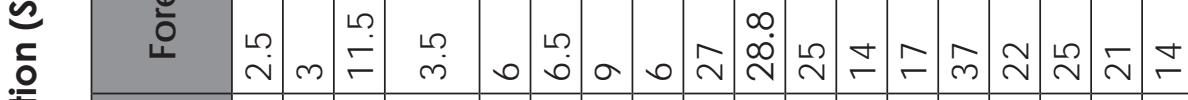

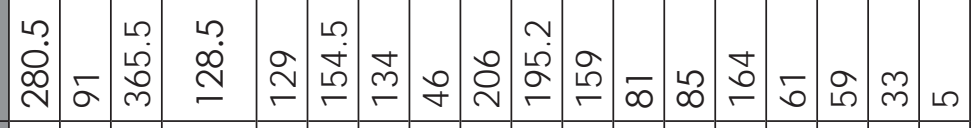

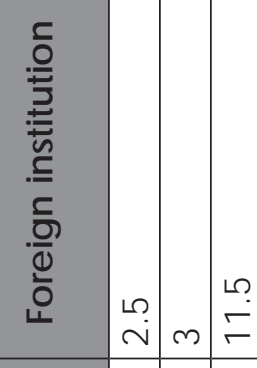

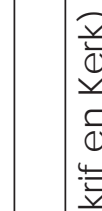

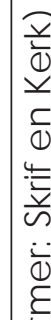

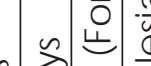

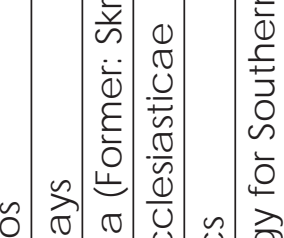

드 U뻐

บ

U)

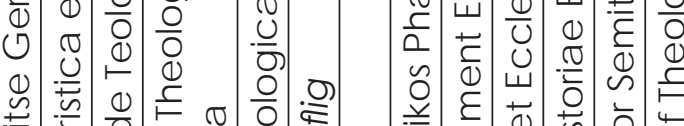

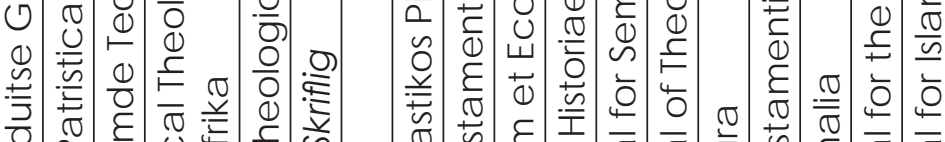
ㅎํㄴ.

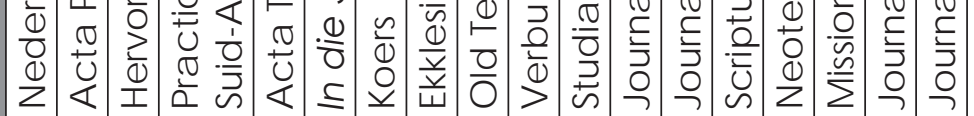

$\frac{\circ}{3}$

هं

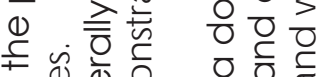

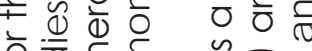

은굴

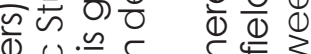

员.

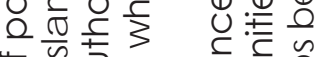

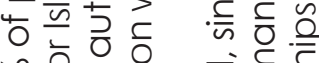

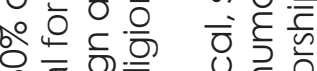

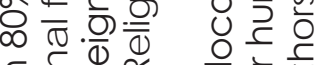

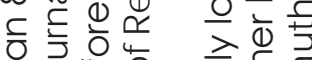

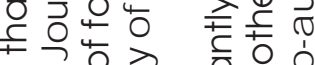

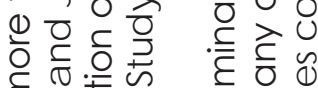

हn 0 o $\varepsilon=\overline{0}$

品응 응돈

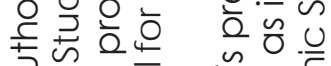

ठ일

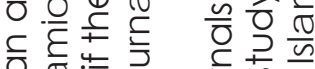

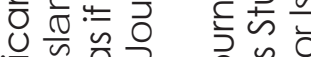

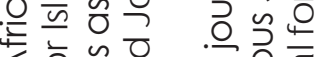

$<4$ है

ᄃ

亏

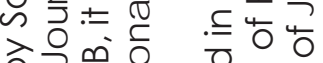

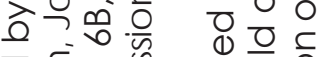

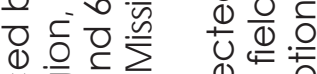

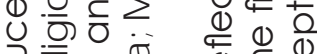

วิ응

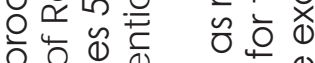

잉

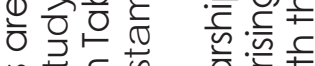

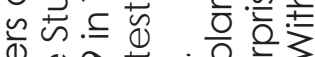
0 ه

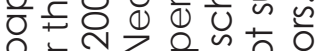

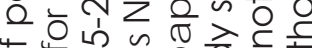

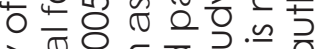

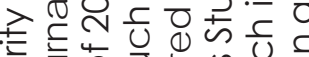

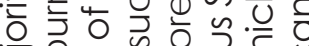

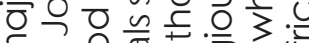

D O음

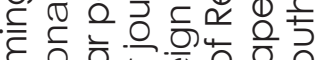
음 0

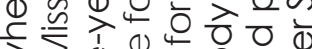
$\sum \sum 0,400$ Q ठᄃ ᄃ

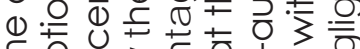

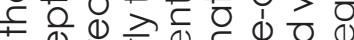
+ .

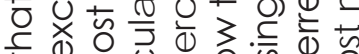
\& $\varepsilon$ 呼 300

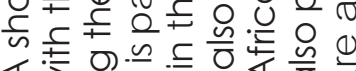

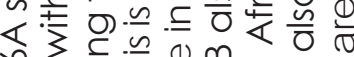
을 응

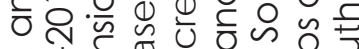

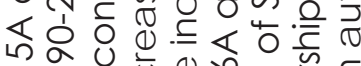

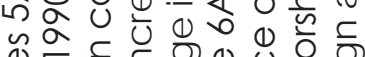

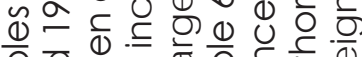

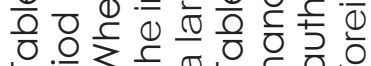




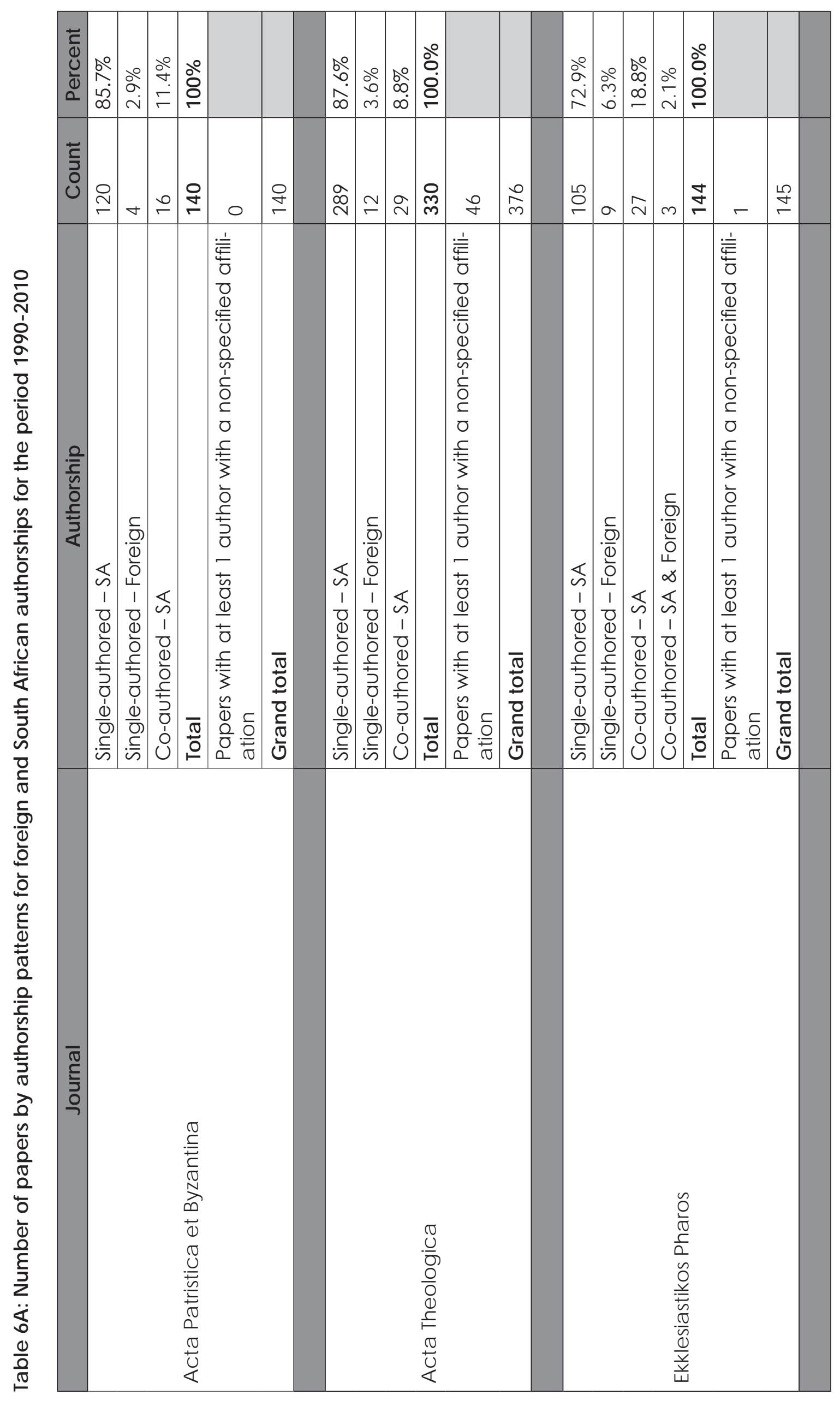




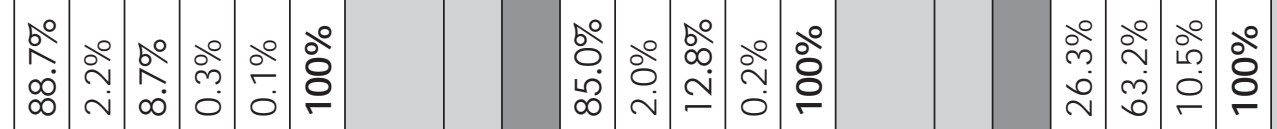

ஸ̆

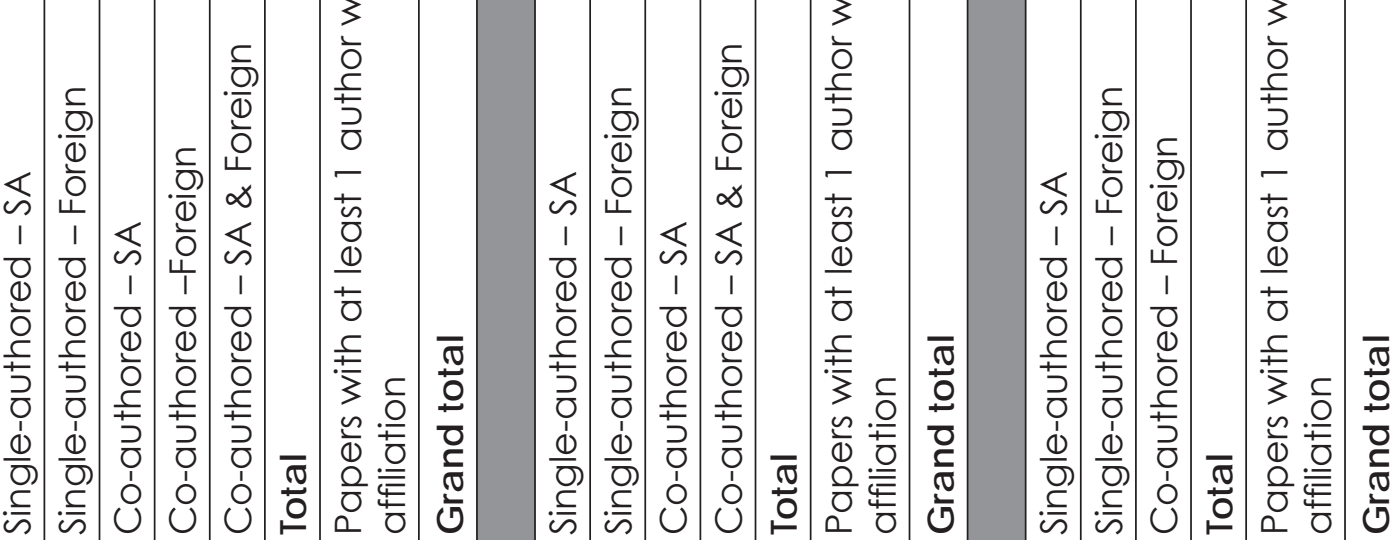

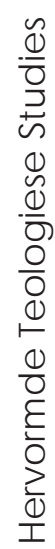

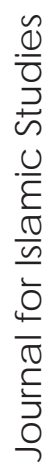




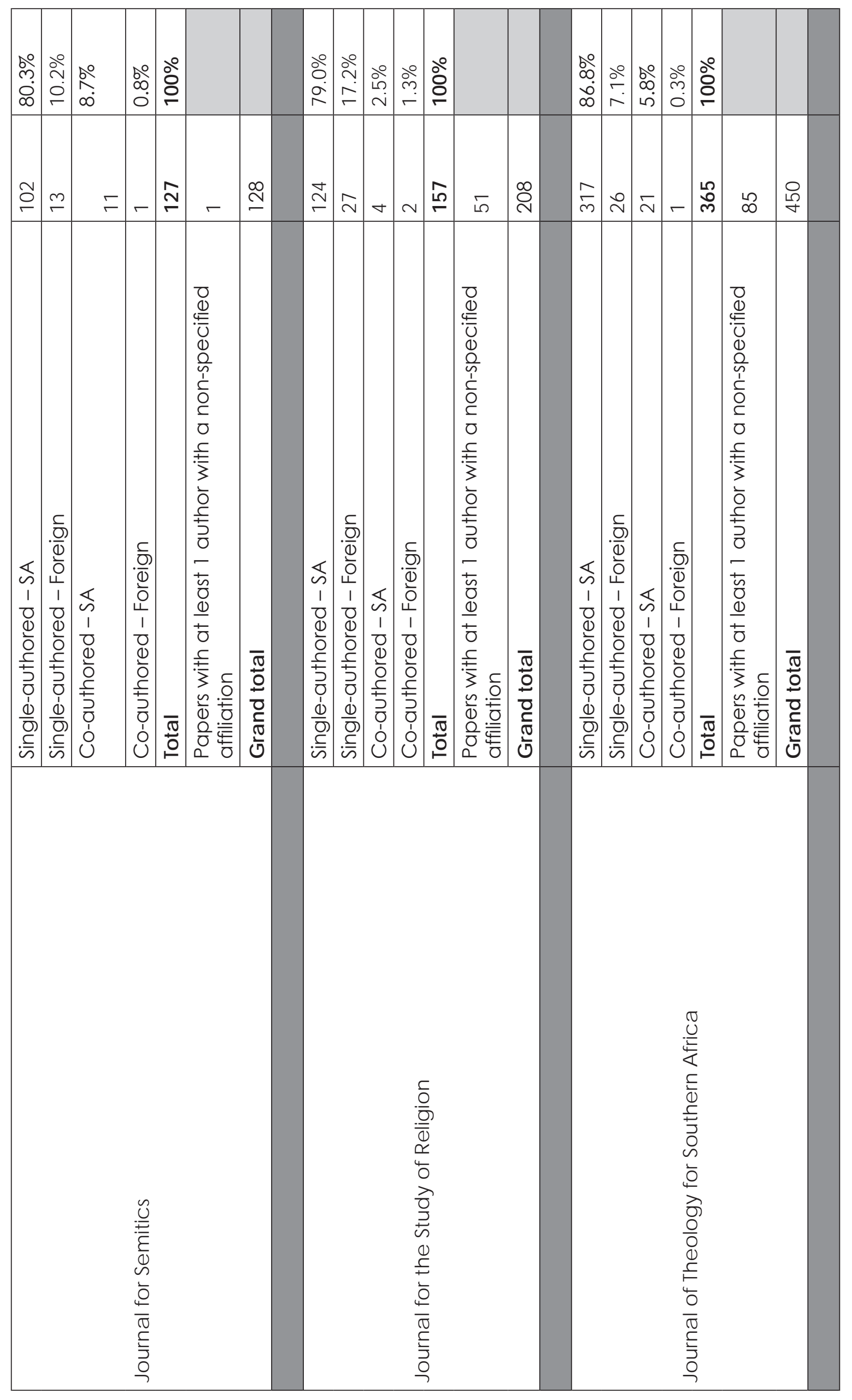


雨吕吕

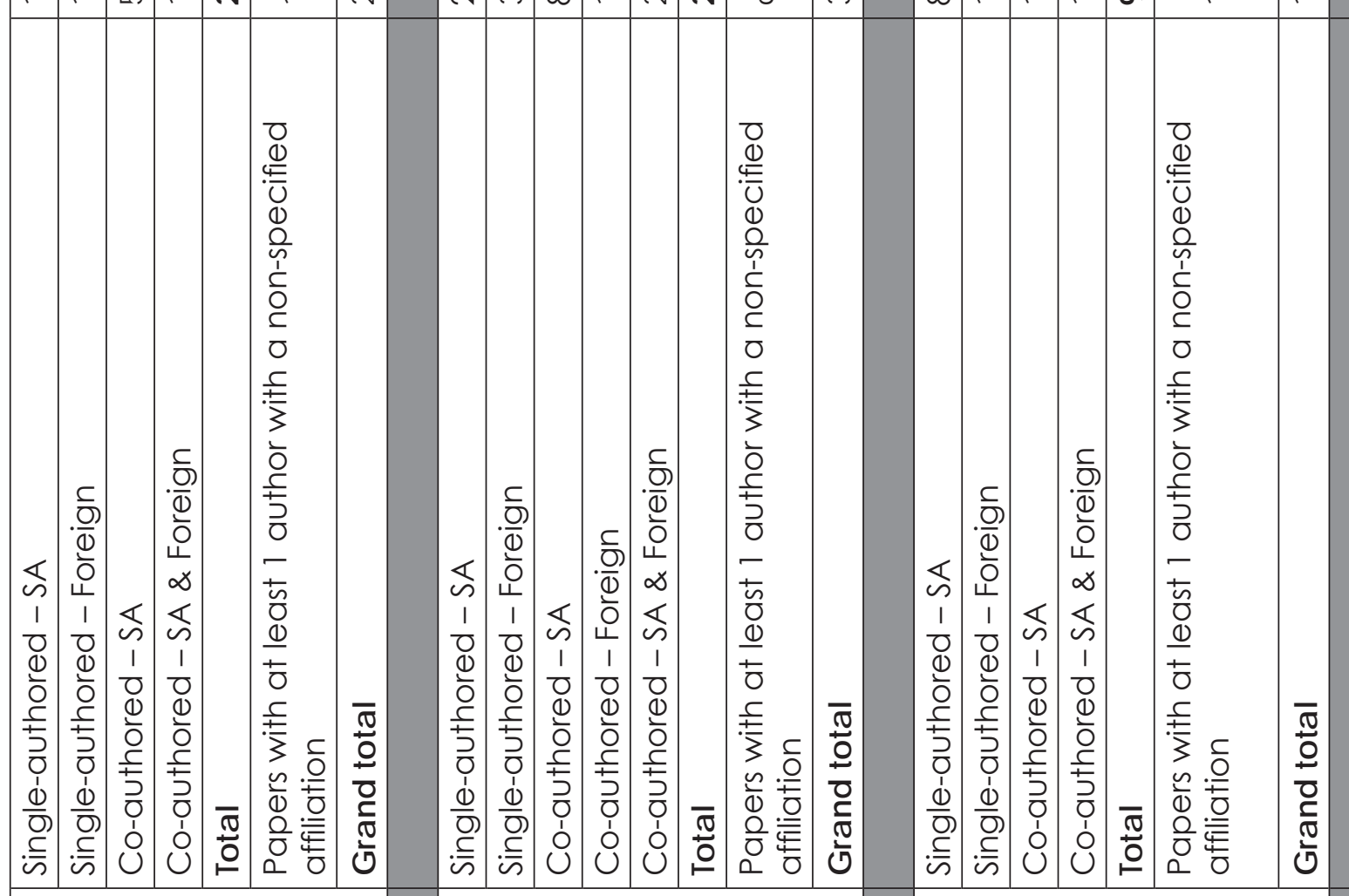


离

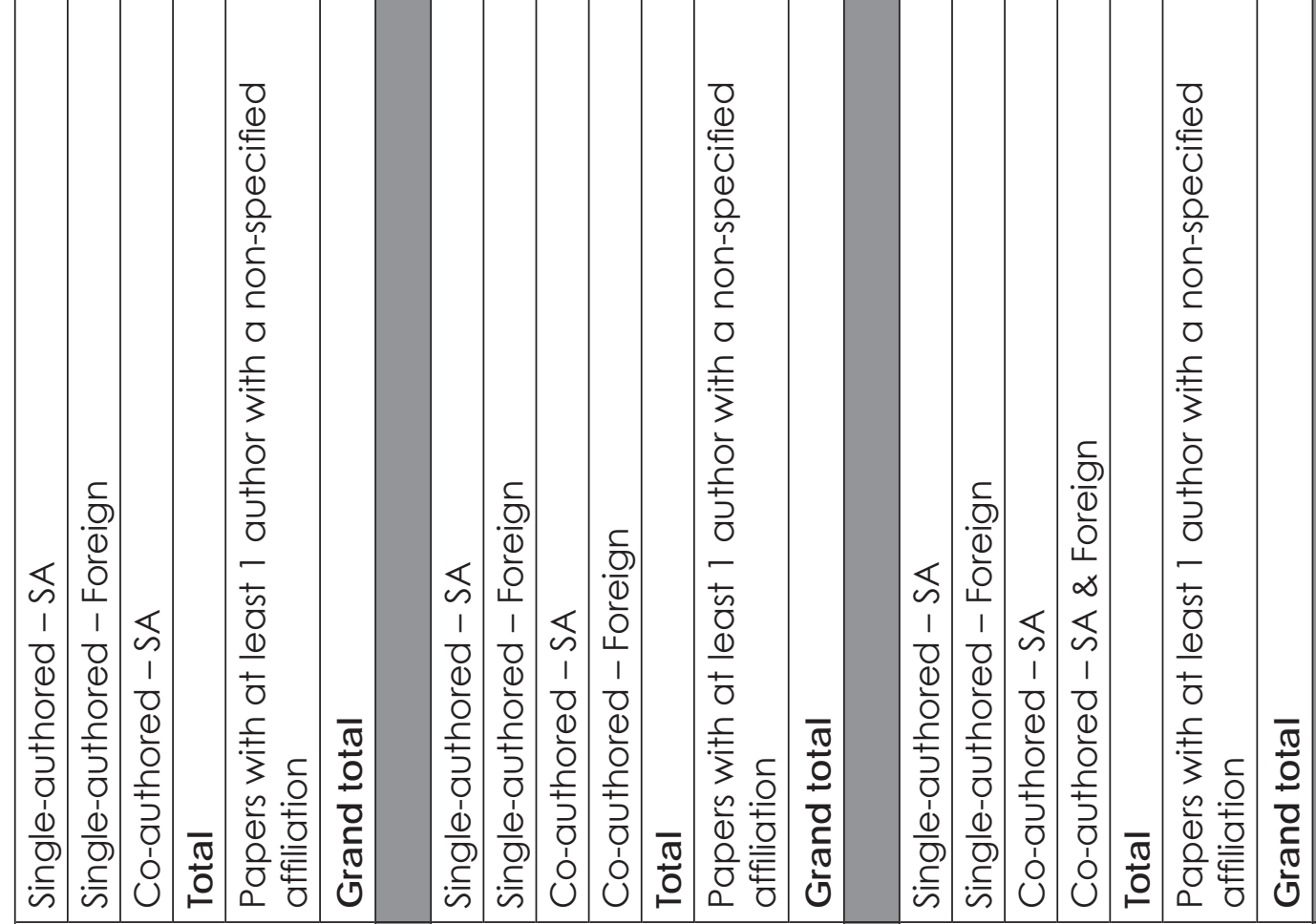

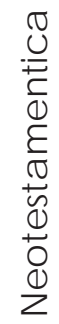
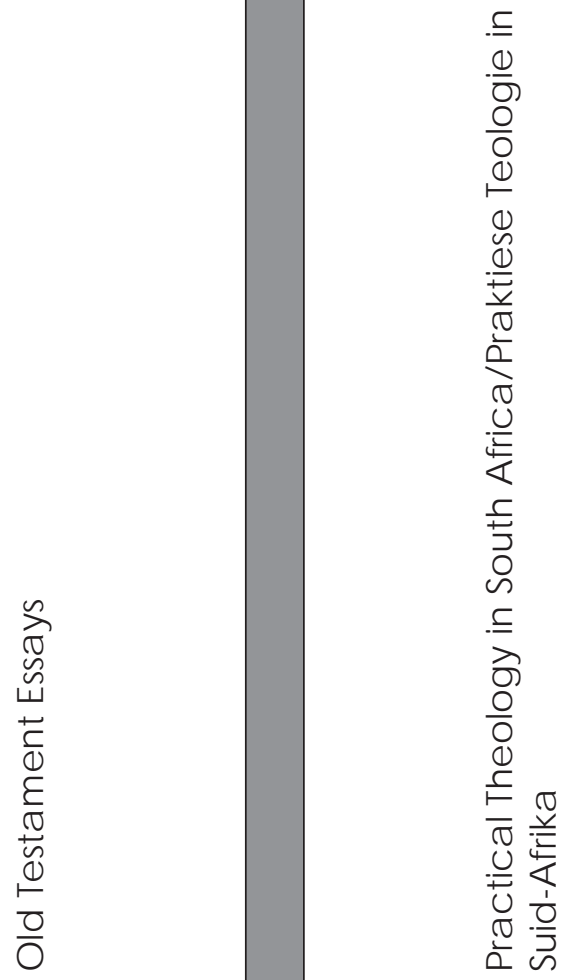


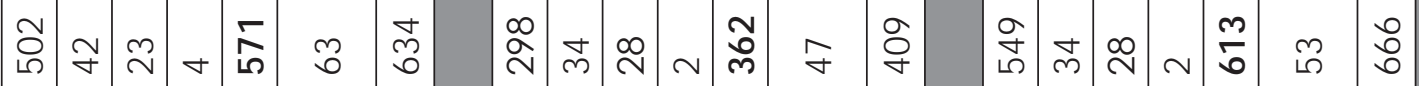

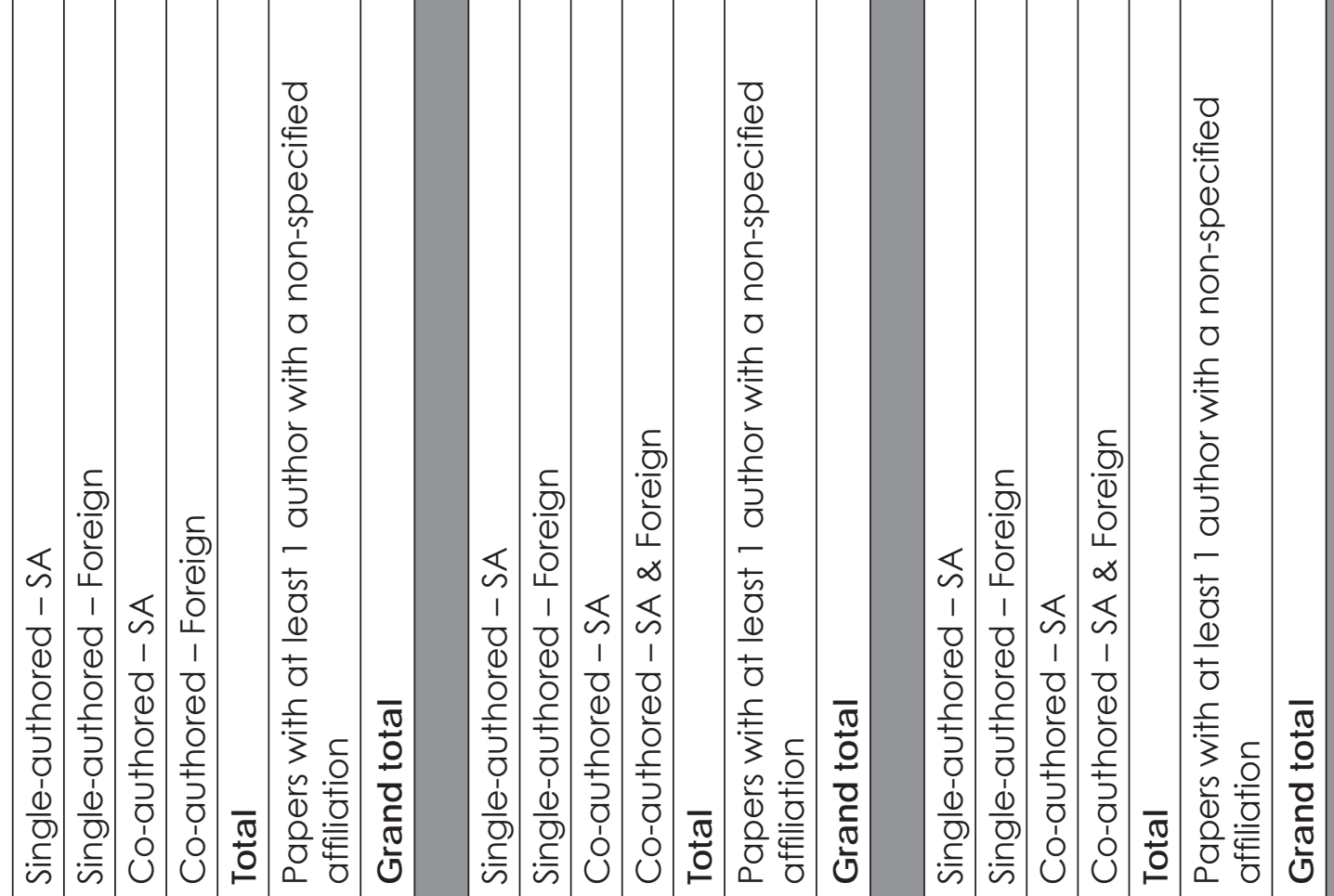

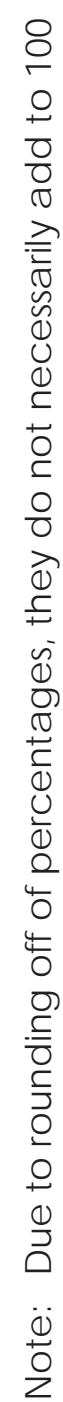




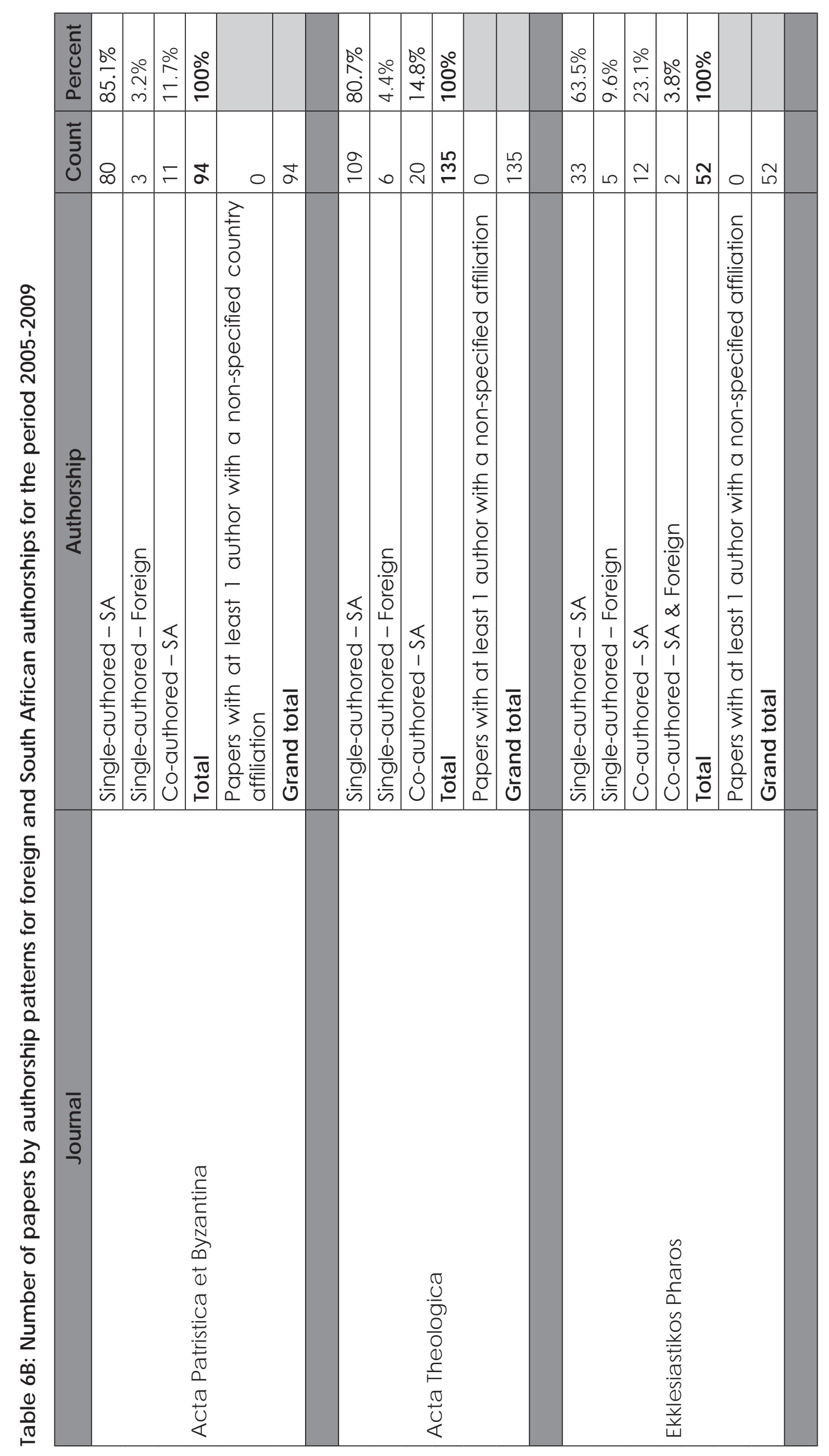




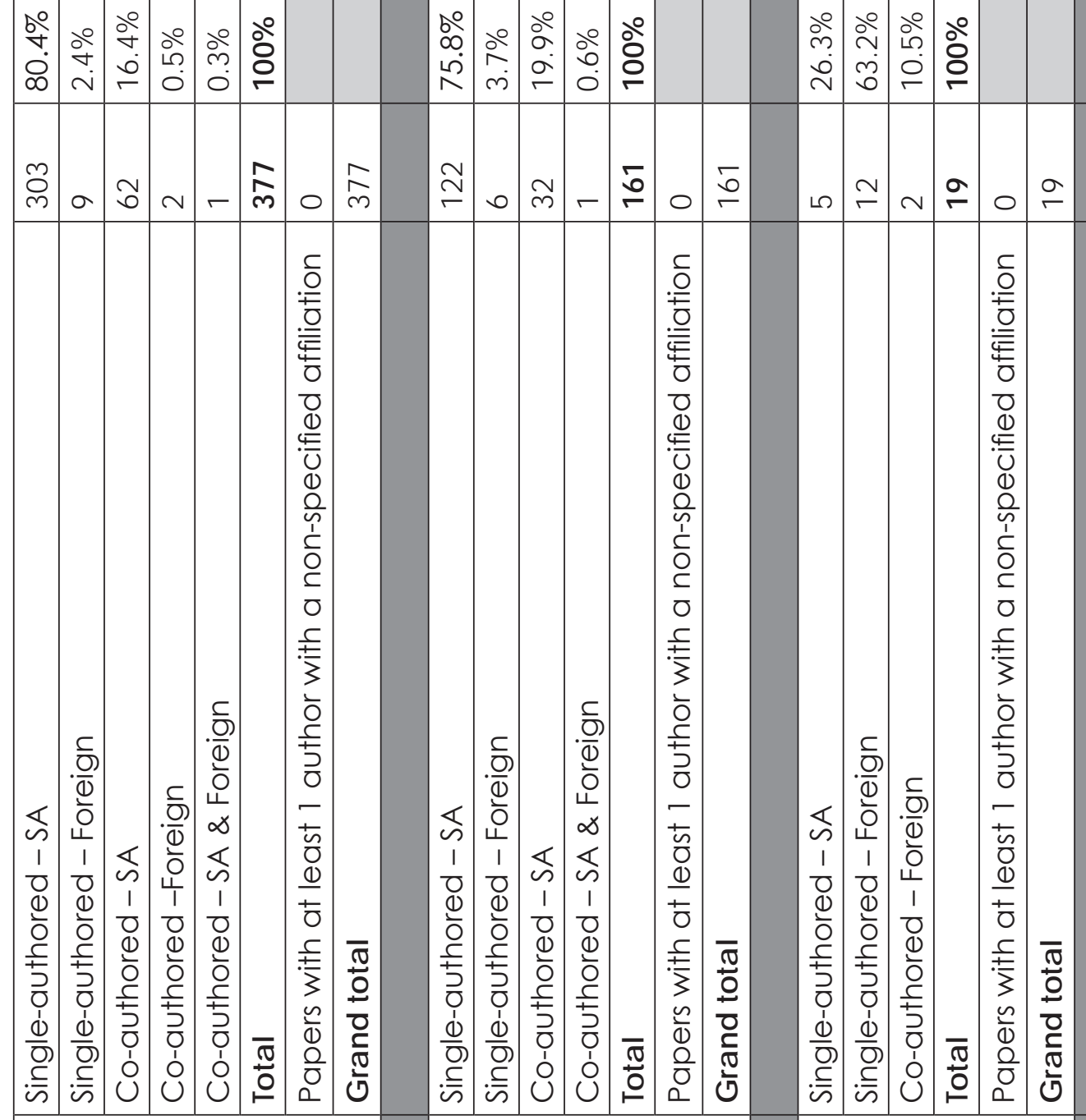

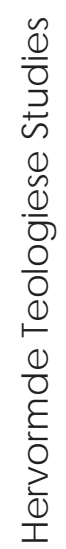

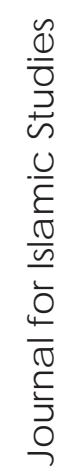




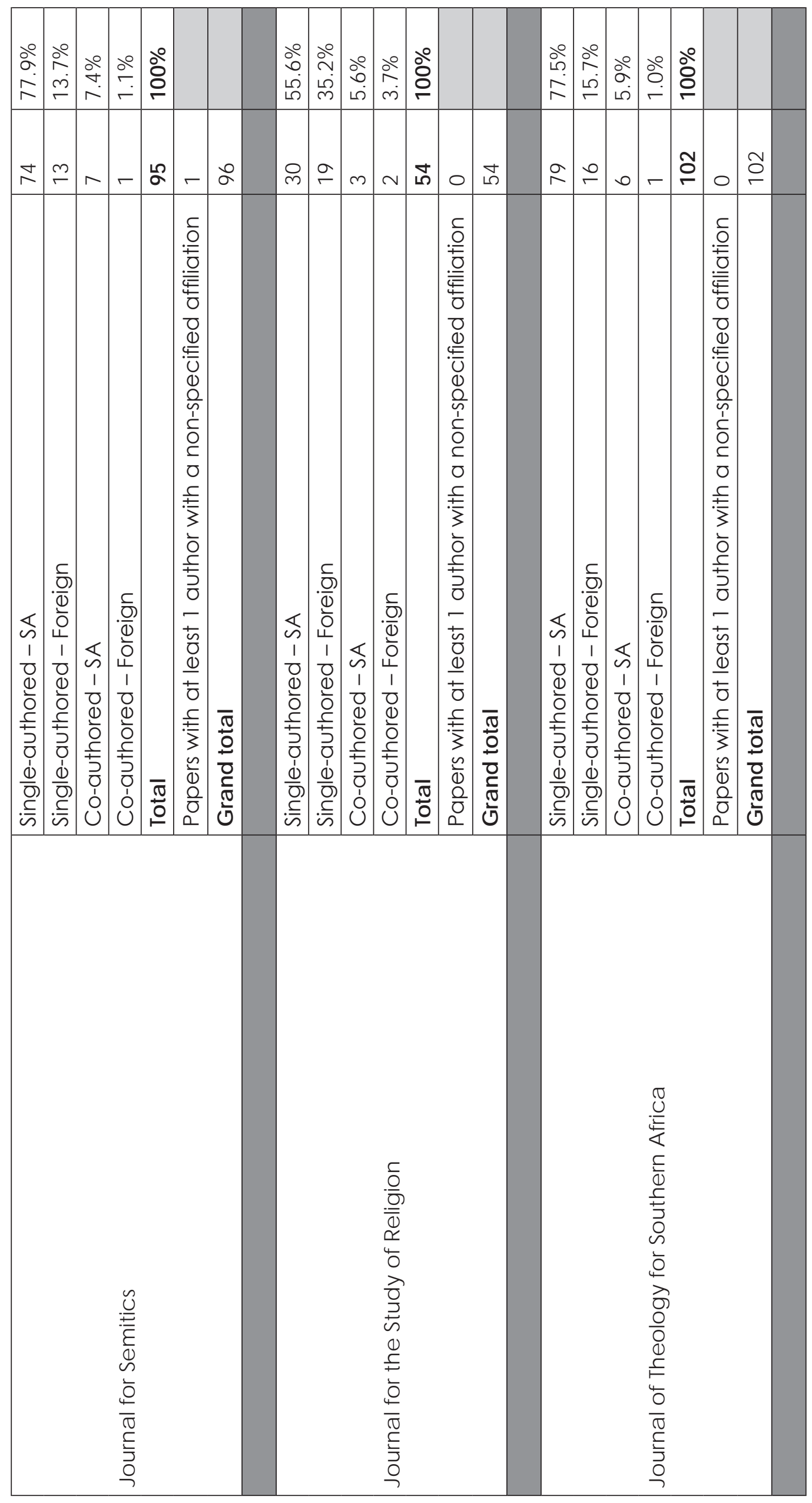




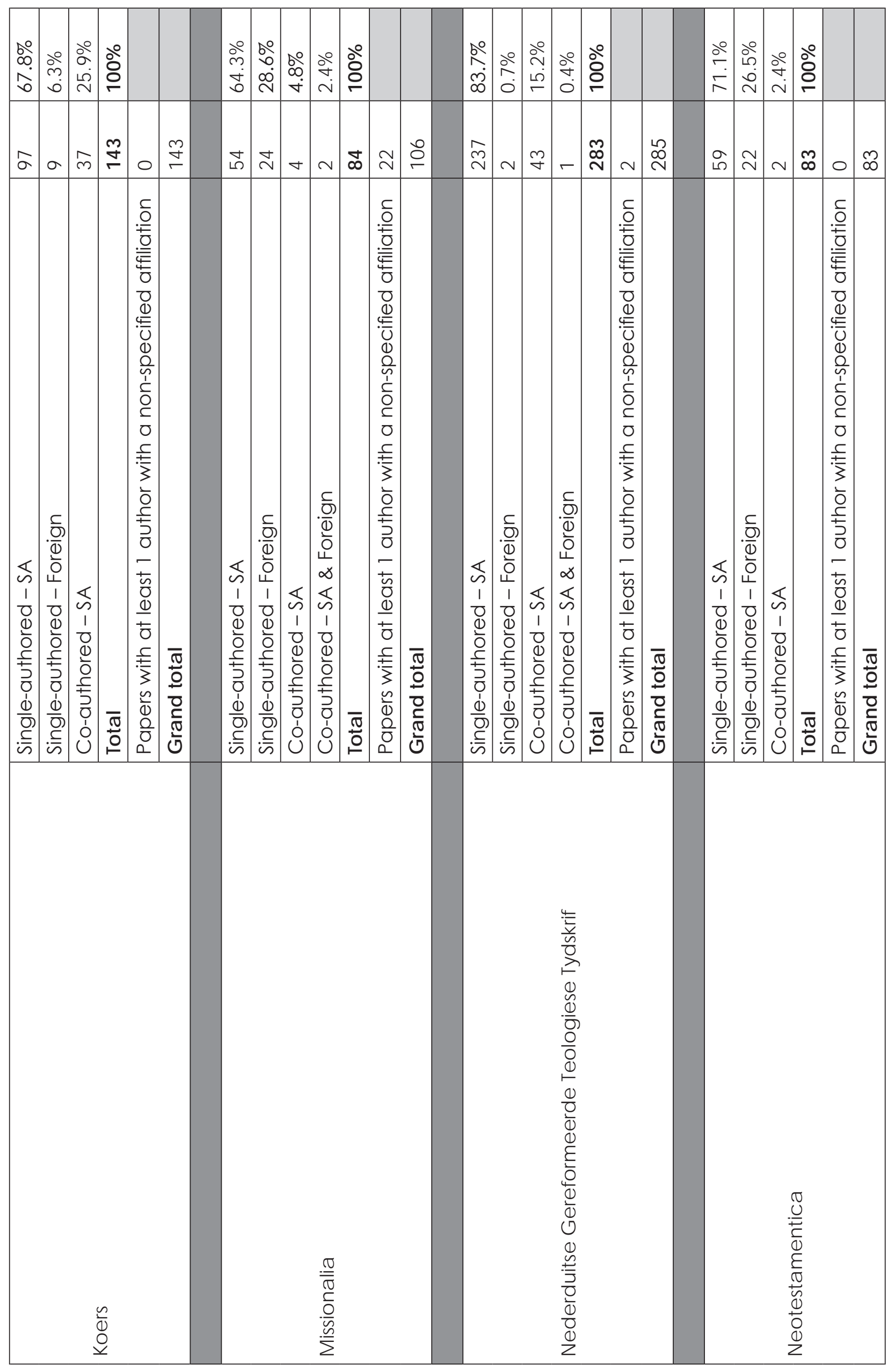




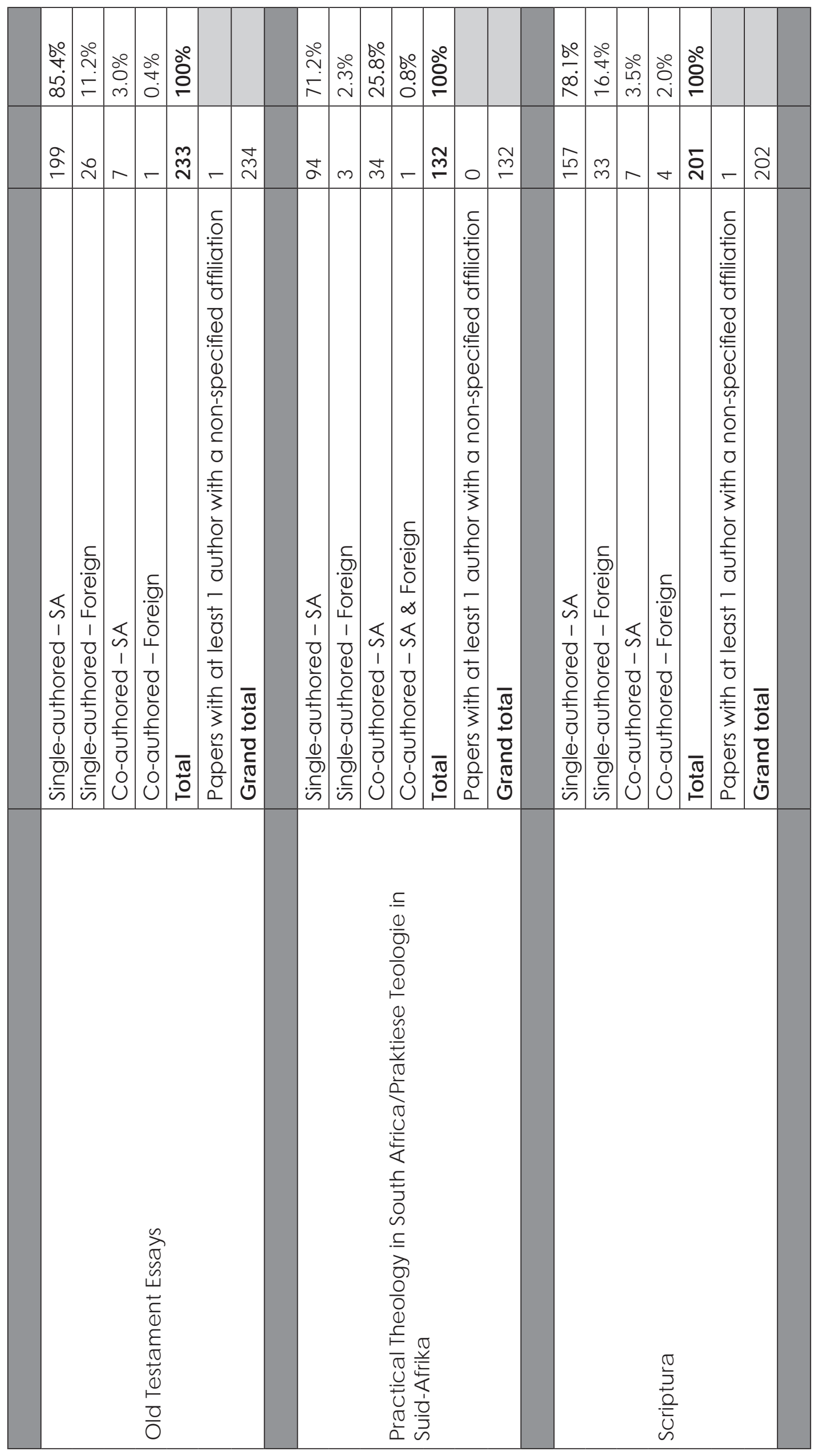



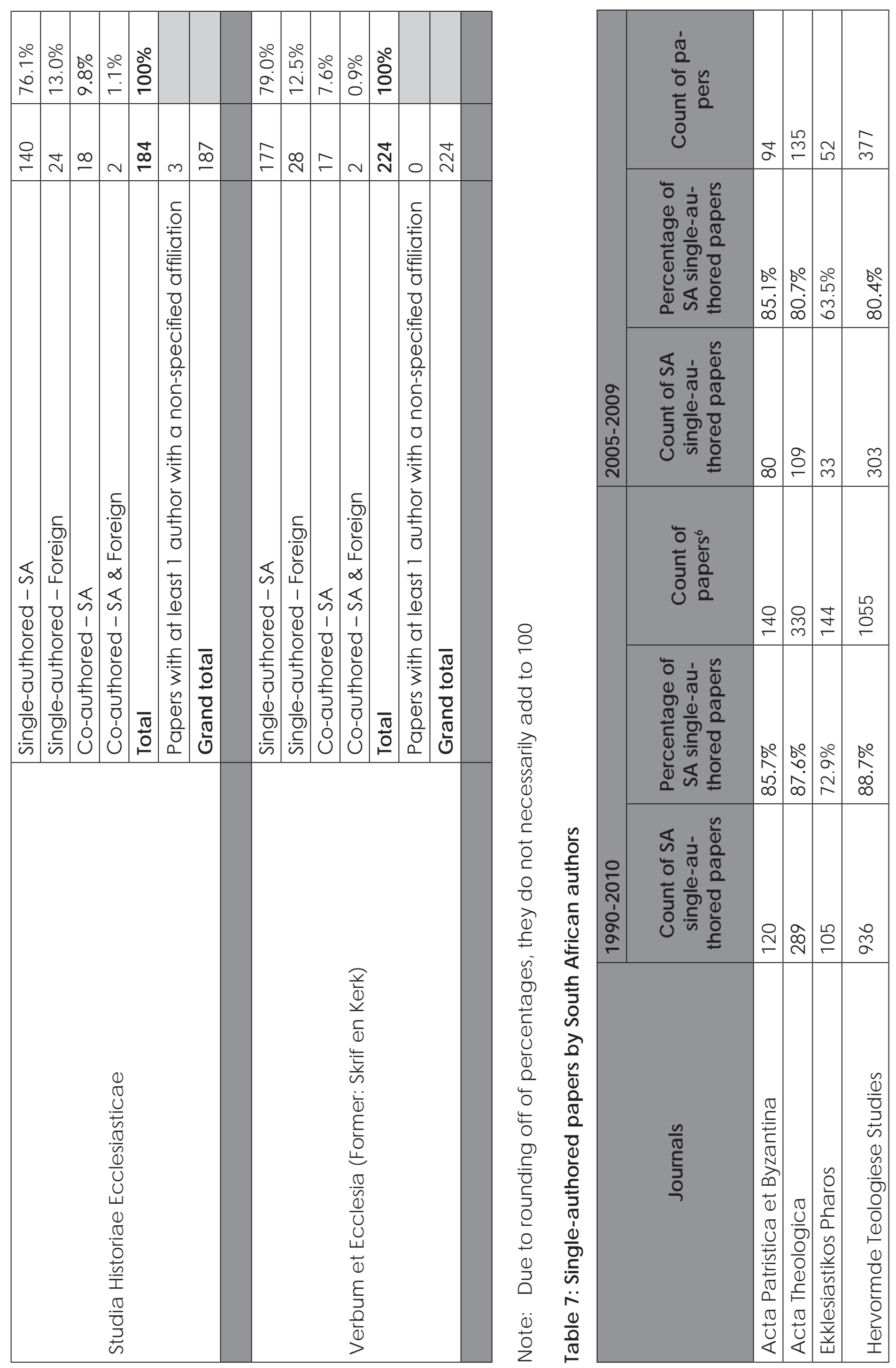


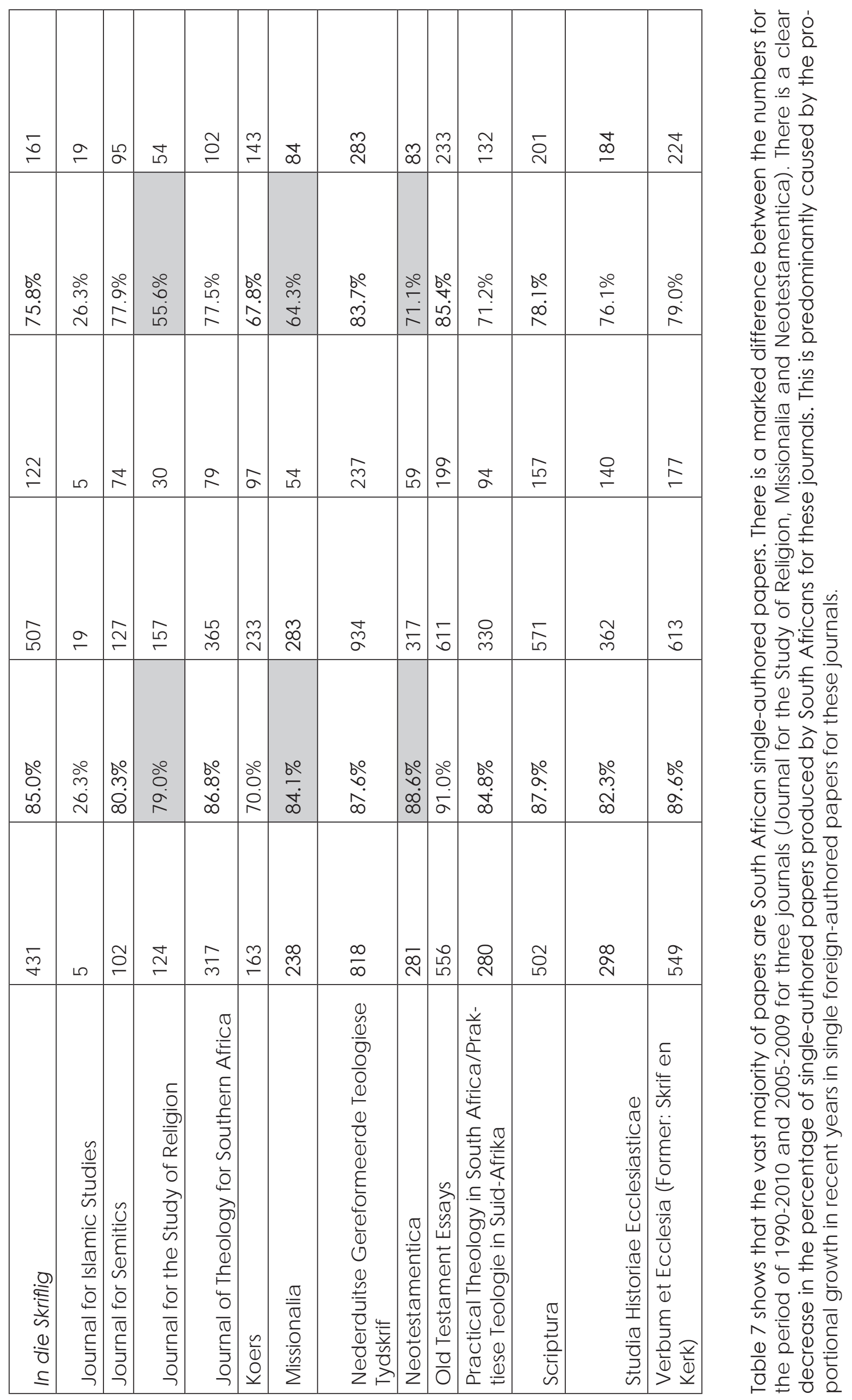




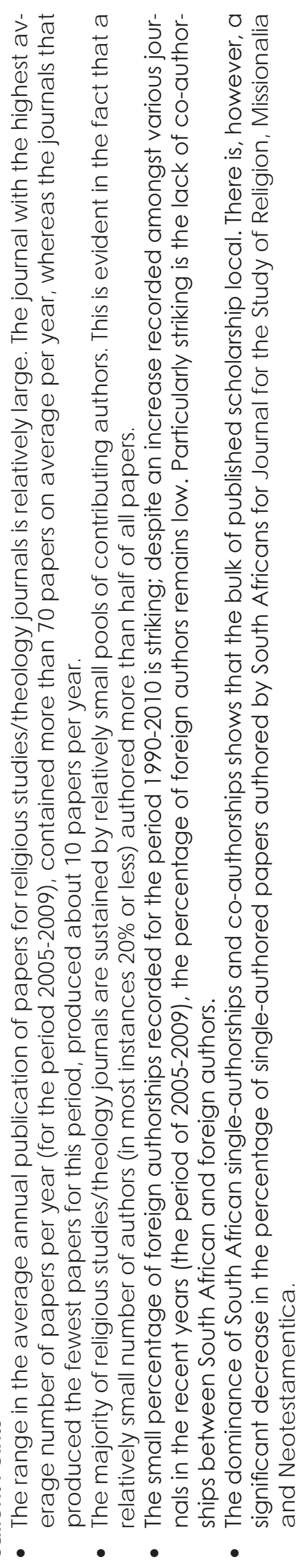



Report on Grouped Peer Review of Scholarly Journals in Religion and Related Fields (RTRF)

\author{
Academy of Science of South Africa (ASSAf) \\ Academy of Science of South Africa
}

Academy of Science of South Africa (ASSAf), (2013). Report on Grouped Peer Review of Scholarly Journals in Religion, Theology and Related Fields (RTRF). [Online] Available at: DOI http://dx.doi.org/10.17159/assaf/0028

http://hdl.handle.net/20.500.11911/71

Downloaded from ASSAf Research Repository, Academy of Science of South Africa (ASSAf) 